I N T ER N ATIONAL MONETARY FUND

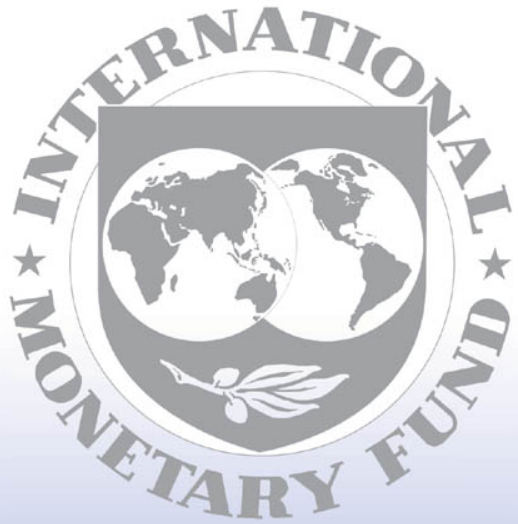

Staff

Country

Reports 


\section{Rwanda: Selected Issues and Statistical Appendix}

This Selected Issues and Statistical Appendix paper for Rwanda was prepared by a staff team of the International Monetary Fund as background documentation for the periodic consultation with the member country. It is based on the information available at the time it was completed on September 21, 2004. The views expressed in this document are those of the staff team and do not necessarily reflect the views of the government of Rwanda or the Executive Board of the IMF.

The policy of publication of staff reports and other documents by the IMF allows for the deletion of market-sensitive information.

To assist the IMF in evaluating the publication policy, reader comments are invited and may be sent by e-mail to publicationpolicy@imf.org.

Copies of this report are available to the public from

International Monetary Fund • Publication Services

700 19th Street, N.W. • Washington, D.C. 20431

Telephone: (202) $6237430 \bullet$ Telefax: (202) 6237201

E-mail: publications@imf.org • Internet: http://www.imf.org

Price: $\$ 15.00$ a copy

International Monetary Fund

Washington, D.C. 
This page intentionally left blank 


\section{INTERNATIONAL MONETARY FUND}

\section{RWANDA}

\section{Selected Issues and Statistical Appendix}

Prepared by Kenneth Meyers (head), Krzysztof Bledowski, Jakob Christensen, David Hauner (all AFR), Gabriel Di Bella, Bjorn Rother (both PDR)

Approved by the African Department

September 21, 2004

Contents

Basic Data.

I. Agricultural Strategy as Part of a Poverty Reduction Program

A. Introduction and Summary

B. Poverty Reduction Strategy Paper and Growth Targets

C. The Market for Fertilizer

D. Conclusion

References

II. Rwanda's Coffee Exports: Past Experience and Lessons for the Future...................... $\underline{36}$

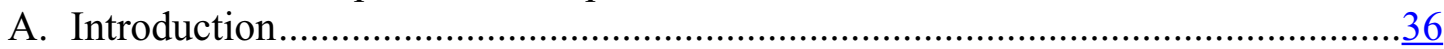

B. Comparative Performance of Rwanda's Coffee Sector .........................................37

C. Price Developments, 1997-2003 ...................................................................

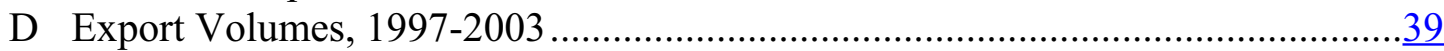

E. Explaining Export Volume Growth: A Cross-country Panel …………………....40

F. Implications for Rwanda's Coffee Sector.............................................................. 43

III. Modeling Rwanda's Money Multipliers and Money Demand ………………............45

A. Introduction and Summary .........................................................................

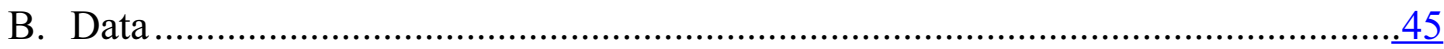

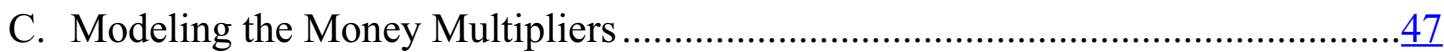

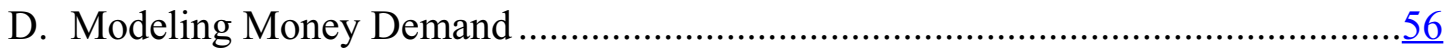

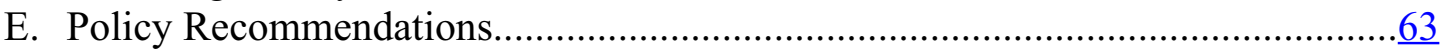

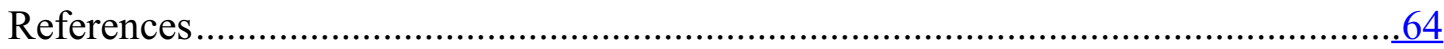

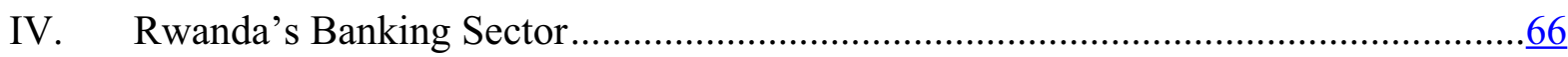

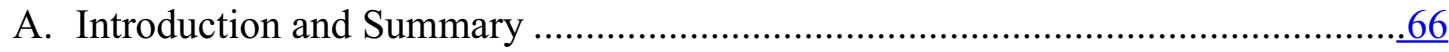

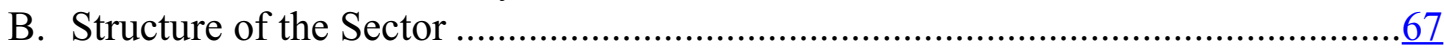

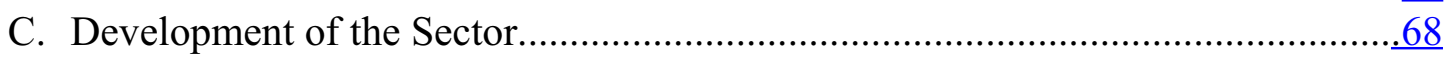

D. Efficiency and Profitability.............................................................................. 


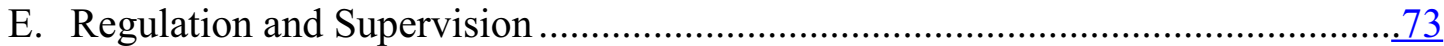

F. The Problem of Asset Quality.........................................................................

G. Capitalization and Restructuring...................................................................77

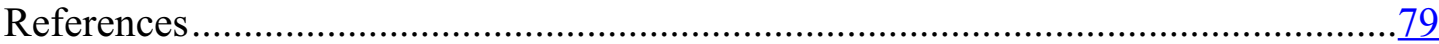

Text Tables

1.1 PRSP's Target Growth Rate for Primary Sectors' GDP .........................................10

1.2 Differences in Agricultural Production Data ……....................................................13

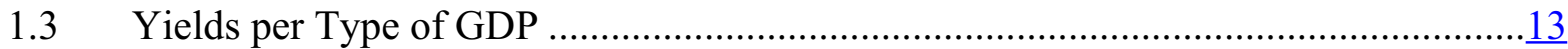

1.4 National Accounts According to Different Official Sources.......................................14

1.5 Estimation of Potential Additional Production Derived from Optimal Fertilizer

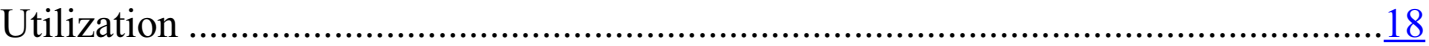

1.6 Agroeconomic Potential and Marginal Physical Product of Fertilizer for Selected Crops Using 2000 as Base Year

1.7 Proposed Schedule for Fertilizer Intensification and Associated Production Increases .........................................................................................

1.8 Proposed Schedule for Fertilizer Intensification and Associated Production Increases ........................................................................................24

1.9 Analysis of the PRSP Target Growth Rate for the Primary Sector ………..................25

1.10 Analysis of the PRSP Target Growth Rate for the Primary Sector ............................26

II.1 Variation of Price Changes Around Mean, 1997-2003 .............................................39

II.2 Correlation Coefficients with Volume Change.........................................................42

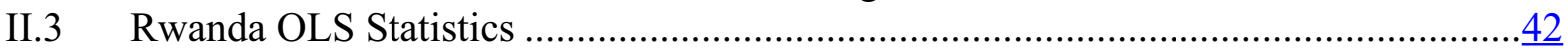

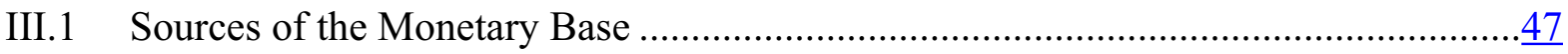

III.2 Descriptive Statistics of the Multipliers and Components........................................49

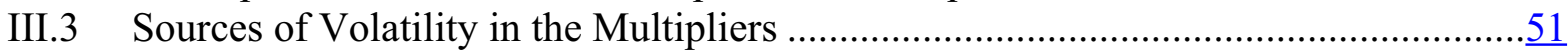

III.4 Preferred Models for Multipliers and Components ……….....................................

III.5 Multipliers Forecast Diagnostics ……….....................................................53

III.6 Variable Specifications ..................................................................................

III.7 Lagged Coefficients of Estimated (Short-term) Money Demand................................. 60

III.8 Structural Coefficient of Estimated (Short-term) Money Demand................................61

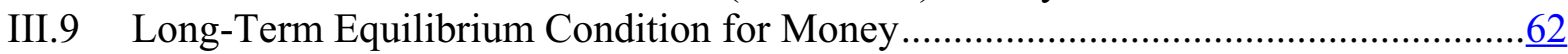

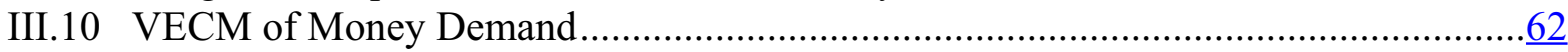

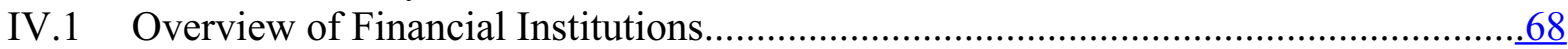

IV.2 Ratio of Broad Money to GDP in Selected Countries ..........................................69

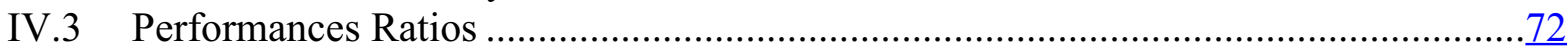

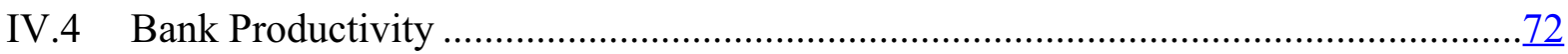

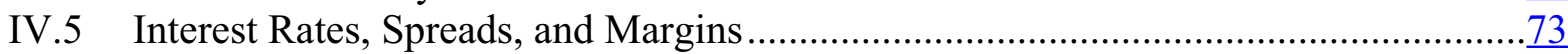

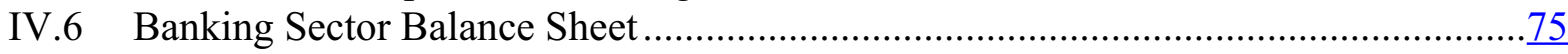

IV.7 Estimated Capital Shortfall in the Sector ............................................................. 
Contents

Figures

II.1. Arabica Coffee: Export Volume and Producer Prices ............................................ $\underline{36}$

II.2a. Arabica Coffee: Price Developments, 1997-2003 Wholesale and Producer Prices .... 38

II.2b. Arabica Coffee: Price Developments, 1997-2003 Comparison of Producer Prices in Rwanda and Other Regions ........................................................................ 38

II.3a. Arabica Coffee: Export Volume Growth Comparison of Rwanda and Sample Average....

II.3b. Arabica Coffee: Export Volume Growth Comparison of Rwanda, Burundi, and African Average....

III.1. The Multipliers and their Components ............................................................... 50

III.2. The Main Variables of the Money Demand Function ...............................................

III.3. The Disequilibrium in the Market for Nominal Money Balances .............................

III.4. Actual and Fitted Money Demand ..................................................................... 62

IV.1. Indicators of Financial Depth......................................................................

IV.2 Commercial Bank Credit and GDP................................................................ 70

IV.3. Commercial Bank Excess Reserves (RF bn) .................................................... 71

IV.4. Bank Lending and Nonperforming Loans .......................................................

Statistical Appendix Tables

1. Gross Domestic Product by Origin at Current Prices, 1999-2003 ........................... $\underline{80}$

2. Gross Domestic Product by Origin at Constant 1995 Prices, 1999-2003 .................. 81

3. Supply and Use of Resources at Current Market Prices, 1999-2003........................ $\underline{82}$

4. Supply and Use of Resources at Constant 1995 prices, $1999-2003$.......................... $\underline{83}$

5. Selected Food Crop Production, 1999-2003 ......................................................84

6. Coffee and Tea Production, Prices, and Costs, 1999-2003 .....................................85

7. Production of Principal Manufactured Goods and Minerals, 1999-2003 .................. $\underline{86}$

8. Energy, Water, and Telephone Production, Consumption, and Prices, 1999-2003 ..... $\underline{87}$

9. Consumer Prices, 1999-2003 ................................................................... $\frac{88}{89}$

10. Budgetary Operations of the Central Government, 1999-2003 ...............................89

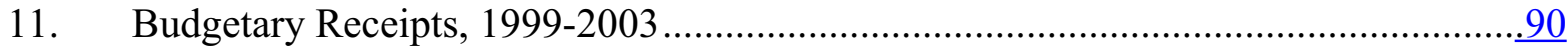

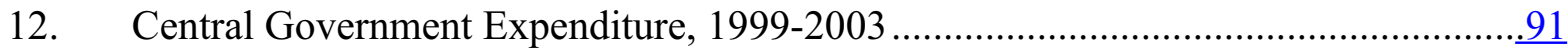

13. Functional Classification of Central Government Recurrent

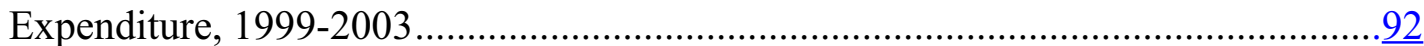

14. Priority Expenditure, 1999-2003 ............................................................... $\frac{93}{94}$

15. Government Domestic Debt by Creditor, 1999-2004 ........................................94

16. Public Enterprises and Public Financial Institutions ............................................95

17. Money Survey, 1999-2004..................................................................... $\frac{96}{97}$

18. Summary Accounts of the National Bank of Rwanda, 1999-2004 .......................... $\frac{97}{98}$

19. Summary Accounts of Commercial Banks, 1999-2003 .........................................98

20. Commercial Bank Credit, 1999-2004 ................................................................ 99

21. Financial Sector Indicators, 1999-2004 ...................................................... 100

22. Interest Rates, 1999-2004 ................................................................. 101 
23. Balance of Payments, 1999-2003 102

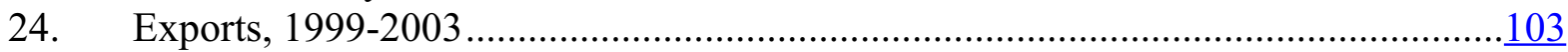

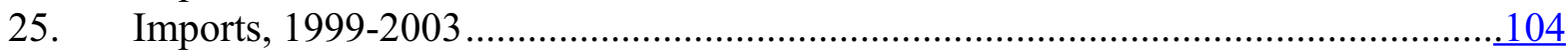

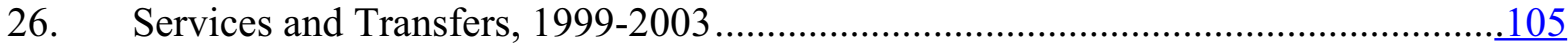

27. Scheduled Principal and Interest, 1999-2003 ……...........................................106

28. External Public Debt, Stock Outstanding, 1999-2003 ……….................................107

29. External Debt, Outstanding Arrears, 1999-2003 ……..........................................108 
Rwanda: Basic Data

I. Social and Demographic Indicators

(2003, unless otherwise indicated)

Area

26,338 square kilometers

Population

Total

8.5 million

Growth rate

2.9 percent

GDP per capita

US $\$ 200$

Infant mortality rate (per 1,000 births; $<1$ year)

99.0

Percentage of children completely immunized $<5$ years

55.0

Life expectancy at birth (years)

40.0

Adult literacy rate (percent of aged 15+)

Men

Women

Net school enrollment ratio (in percent of relevant age group)

Primary

Secondary

Tertiary

Access to safe water (percent)

II. Economic Indicators, 1999-2003

$\begin{array}{lllll}1999 & 2000 & 2001 & 2002 & 2003\end{array}$

Gross domestic product

GDP at constant 1995 prices 1/

Primary sector

Secondary sector

Tertiary sector

$\begin{array}{rrrrr}509.8 & 540.3 & 576.6 & 630.7 & 636.7 \\ 223.6 & 243.9 & 264.2 & 302.5 & 293.0 \\ 86.8 & 89.7 & 96.6 & 104.3 & 108.9 \\ 199.5 & 206.6 & 215.8 & 223.9 & 234.7\end{array}$

GDP at current market prices

$\begin{array}{rrrrr}644.9 & 705.7 & 754.3 & 825.0 & 905.3 \\ 574.0 & 622.4 & 646.9 & 727.1 & 775.7 \\ 71.2 & 74.3 & 87.9 & 97.7 & 137.1 \\ 111.1 & 123.7 & 138.9 & 139.6 & 166.8 \\ 38.2 & 58.9 & 69.6 & 63.2 & 75.0 \\ 149.6 & 173.5 & 189.0 & 202.5 & 249.4\end{array}$

Private consumption

Public consumption

Gross investment

Exports 2/

Imports 2/

149.6

173.5

189.0

202.5

249.4

Price indices

GDP deflator

Consumer price index (period average)

Export price index (in U.S. dollars)

Import price index (in U.S. dollars)

$\begin{array}{rrrrr}-3.5 & 3.3 & 0.2 & 0.0 & 8.7 \\ -2.4 & 3.9 & 3.4 & 2.0 & 7.4 \\ -14.2 & 20.9 & -23.8 & -13.2 & 7.9 \\ 2.9 & 12.7 & -3.0 & 5.4 & 3.5\end{array}$


Rwanda: Basic Data (concluded)

\begin{tabular}{|c|c|c|c|c|c|}
\hline & 1999 & 2000 & 2001 & 2002 & 2003 \\
\hline & \multicolumn{5}{|c|}{ (In billions of Rwanda francs) } \\
\hline \multicolumn{6}{|l|}{ Government finance } \\
\hline Total revenue and grants & 100.7 & 136.9 & 148.2 & 160.3 & 195.5 \\
\hline Revenue & 63.6 & 68.7 & 86.2 & 101.2 & 122.3 \\
\hline Grants & 37.1 & 68.2 & 62.0 & 59.1 & 73.1 \\
\hline Total expenditure and net lending 3 / & 126.5 & 131.7 & 158.1 & 175.9 & 217.8 \\
\hline Current & 86.0 & 89.2 & 107.4 & 134.6 & 162.7 \\
\hline Capital & 40.8 & 42.0 & 50.0 & 40.7 & 51.1 \\
\hline Domestically financed & 5.3 & 1.5 & 3.5 & 6.9 & 13.2 \\
\hline Externally financed & 35.5 & 40.5 & 46.5 & 33.8 & 37.9 \\
\hline Net lending & -0.4 & 0.5 & 0.6 & 0.6 & 4.0 \\
\hline Overall deficit, including grants $3 /$ & -25.8 & 5.1 & -9.9 & -15.6 & -22.3 \\
\hline Domestic financing & 6.2 & -12.2 & 1.7 & 0.4 & 5.2 \\
\hline Of which : banking system & 7.1 & -9.2 & -0.4 & 2.8 & 5.3 \\
\hline External financing (net) & 21.5 & 11.4 & 40.9 & 30.5 & 22.0 \\
\hline \multicolumn{6}{|l|}{ Money and credit (end of period) 4/ } \\
\hline Foreign assets (net) & 44.9 & 66.9 & 81.0 & 103.7 & 104.0 \\
\hline Domestic credit & 94.0 & 94.8 & 95.1 & 90.0 & 118.6 \\
\hline Claims on government (net) & 34.2 & 24.2 & 18.1 & 1.9 & 17.5 \\
\hline Claims on the economy (including public enterprises) & 59.8 & 70.6 & 77.0 & 88.0 & 101.1 \\
\hline \multirow[t]{2}{*}{ Other items (net) } & -34.6 & -42.4 & -45.9 & -48.6 & -55.7 \\
\hline & \multicolumn{5}{|c|}{ (In millions of U.S. dollars, unless otherwise indicated) } \\
\hline \multicolumn{6}{|l|}{ Balance of payments } \\
\hline Exports, f.o.b. & 62.0 & 89.8 & 93.5 & 67.3 & 63.0 \\
\hline Of which: coffee & 26.5 & 22.5 & 19.4 & 14.6 & 15.0 \\
\hline Imports, f.o.b. & 248.8 & 239.8 & 237.9 & 234.7 & 244.0 \\
\hline Trade balance & -186.7 & -150.1 & -144.4 & -167.4 & -181.0 \\
\hline Services (net) & -143.0 & -141.4 & -125.3 & -125.1 & -143.4 \\
\hline Private current transfers (net) & 18.2 & 11.0 & 21.7 & 24.5 & 31.3 \\
\hline Official current transfers (net) & 175.5 & 205.6 & 170.1 & 170.3 & 192.5 \\
\hline Current account balance (including official transfers) & -147.5 & -90.2 & -100.3 & -116.7 & -131.1 \\
\hline Gross official reserves (end of period) & 174.2 & 190.6 & 212.1 & 243.6 & 214.2 \\
\hline Nominal trade-weighted effective exchange rate $(1990=100)$ & 43.1 & 37.5 & 36.8 & 31.1 & 29.9 \\
\hline Real trade-weighted effective exchange rate $(1990=100)$ & 93.1 & 83.2 & 80.2 & 70.2 & 67.6 \\
\hline
\end{tabular}

Sources: Rwandese authorities; World Bank; and Fund staff estimates.

1/ Including net indirect taxes (not included in the three sectors shown below).

2/ Goods and nonfactor services.

3/ Payment order basis.

4/ Actual figures are based on current exchange rates. 


\section{Agricultural Strategy as Part of a Poverty Reduction Program ${ }^{1}$}

\section{A. Introduction and Summary}

1. This paper analyzes the growth strategy as described in Rwanda's Poverty Reduction Strategy Paper (PRSP). The PRSP constitutes a critical (ongoing) effort aimed at generating poverty-reducing economic growth. Given the many aspects of the overall strategy presented, this paper will focus on the elements of the strategy with a substantial macroeconomic significance.

2. Poverty in Rwanda is mainly a rural phenomenon, as rural population constitutes about 90 percent of the total, and agricultural productivity in Rwanda is relatively low, even by sub-Saharan African standards. As extreme poverty occurs largely among the rural landless, the PRSP targets high and sustained rates of agricultural growth, to be achieved through agricultural intensification and, in particular, through the use of improved seeds and the increased use of chemical fertilizers.

3. This paper focuses on the analysis of this strategy, assessing its coherence, and developing policy issues that will need to be taken into consideration in the formulation of appropriate sectoral strategies.

4. The remainder of the paper is organized as follows: Section B describes the main elements of the growth strategy included in Rwanda's PRSP. Section C focuses on the market for fertilizer, describing its current workings and analyzing possible problems that prevent high volumes of effective demand to materialize. Section D draws the conclusions. Appendices provide supplementary information on issues addressed in the main text.

\section{B. Poverty Reduction Strategy Paper and Growth Targets}

5. Poverty in Rwanda is severe. With an average GDP per capita in current US\$ terms of US\$200, 60 percent of the population was living in poverty in 2002. Thus, in order to achieve a meaningful improvement in living conditions, overall annual real GDP growth targets under the PRSP are set at 6 percent, compared to the estimated annual population growth rate of 2.5-2.9 percent.

6. Rwanda's PRSP strategy targets poverty reduction through productivity growth in the primary sector, especially agriculture. ${ }^{2}$ The strategy draws on a series of papers written under the Agricultural Policy Development Project (APDP). ${ }^{3}$

\footnotetext{
${ }^{1}$ Prepared by Gabriel di Bella and Krzysztof Bledowski. Based on a draft Working Paper by Gabriel di Bella.

${ }^{2}$ See the PRSP (GoR (2002c)), Chapter 3, page 30.

${ }^{3}$ Key papers underpinning the strategy were written by Mellor (2002a,b) and Mellor and Ranade (2002a). Other contributions under the APDP include those by Crissman (2002), Goosens (2002) and De Rosa and
} 
Under this strategy:

- $\quad$ Sustained growth in the primary sector (5.3 percent per year for a period of five to seven years) serves as an engine of growth in the rural non-tradable sector. The consequent rural employment generation provides income to the rural landless - the poorest among the rural poor (as is the case for most sub-Saharan African countries, see Khan (2000)).

- In generating an annual rural non-farm growth rate of 6.7 percent, the PRSP assumes an elasticity of rural non-farm activities with respect to farm growth.

- $\quad$ To complete the strategy, the PRSP assumes that the rate of growth of the urban formal sector also reacts to the growth of the primary sector. The posited elasticity results in an annual rate of growth of 7 percent for the urban formal sector.

- $\quad$ Finally, the PRSP argues for an elasticity of urban informal sector growth with respect to urban formal sector growth that leads to a growth rate of 9.2 percent per year for the urban informal sector. ${ }^{4}$

7. In short, reduced to its bare frame, the PRSP posits that achieving sustained agricultural productivity growth will generate substantially larger productivity increases in other economic sectors. Strong growth in the primary sector is driven by an assumed robust response of (rural) employment to increases in demand for rural non-farm products. Increases in farm income generate both direct effects through the improvement in the situation of farmers, and indirect effects through the generation of non-farm rural activities that, in turn, decrease (the posited high) rate of rural unemployment, and decrease extreme poverty. ${ }^{5}$ Mellor (2002a) argues that, given the substantial share of agriculture in GDP, it would be

others (2002). The target growth rate for the primary sector under PRSP, as well as its rationale, are taken from Mellor (2002a).The Primary Sector growth strategy in Mellor (2002a) is complemented by a Rural Works Program that targets the rural non-farm poor (Mellor (2002b)). The latter three papers set out a strategy for a crop strongly responsive to fertilizer (Irish potato) and analyzes the possible economic impact of trade liberalization in Rwanda.

\footnotetext{
${ }^{4}$ These figures are identical to those in Mellor (2002a); however, there are some differences in wording: while the PRSP states that the 7 percent growth in the formal urban sector results from the growth in the primary sector, Mellor (2002a) states that this growth is arbitrarily assumed. (See page 30, PRSP and Mellor (2002a) page 28). The 6.7 percent growth in the non-farm rural sector results from an elasticity of 1.5 in excess of the population growth, i.e. $6.7=(5.3-2.5) * 1.5+2.5$, where 2.5 is the rate of population growth. The same rationale lies behind the 9.2 percent growth rate in the informal urban sector $(9.2=(7.0-2.5) * 1.5+2.5)$. Finally, note that the PRSP does not link these assumptions to the description of the expected sources of growth in the secondary sector based on the expansion of specific manufacturing capacity, including tobacco and brewing (see page 75, PRSP)
}

${ }^{5}$ Mellor $(2002 \mathrm{a}, \mathrm{b})$ assumes that the rate of rural unemployment is around 14 percent; however, there are no official estimates for this figure. 
difficult to find an alternative engine of both effective demand and employment, taking into consideration the relative unimportance of other economic sectors.

8. Given the centrality of this growth strategy to the achievement of Rwanda's longterm objectives, it is worth reviewing the soundness of the growth model and the supporting analysis.

\section{Are PRSP target growth rates consistent with existing data?}

9. While agricultural growth constitutes the core of the overall growth strategy described in the PRSP, the coherence of the data set comprising agricultural production in Rwanda is questionable. As will be set out below, these uncertainties call into question the target growth rates for the agricultural sector. ${ }^{6}$

10. According to national accounts statistics, Rwanda's Primary Sector is composed of food crops, export crops, livestock and other. Table 1 shows average prices for food crops and export crops in 2000, and also, volumes of production for these crops according to the figures published in GoR (2002a). ${ }^{7}$ These figures constitute the basis for the calculation of Rwandan national accounts (and are consistent with the figures reported in IMF's Staff Report (IMF (2002a)) and Statistical Appendix (IMF (2002b)). Table 1 also shows production volumes for selected food crops according to a survey conducted by the Food Security Research Project (FSRP) jointly with the Rwandan Ministry of Agriculture (MINAGRI/FSRP (2001)) during the agricultural seasons A and B of 2000 (2002a). ${ }^{8}$ In addition, Table 1 displays the target growth rates for each food crop specified in the PRSP.

\footnotetext{
${ }^{6}$ This paper follows the recommendations expressed in the PRSP's Joint Staff Assessment, which emphasizes the need for further analytical work regarding the growth strategy.

${ }^{7}$ The figures in GoR(2002a) are also referred to as "National Accounts" in the tables that will follow.

${ }^{8}$ The FSRP is managed by Michigan State University and is also funded by USAID. For a complete list of references, go to http://www.aec.msu.edu/agecon/fs2/rwanda/index.htm.
} 
Table I.1. PRSP's Target Growth Rate for Primary Sector's GDP

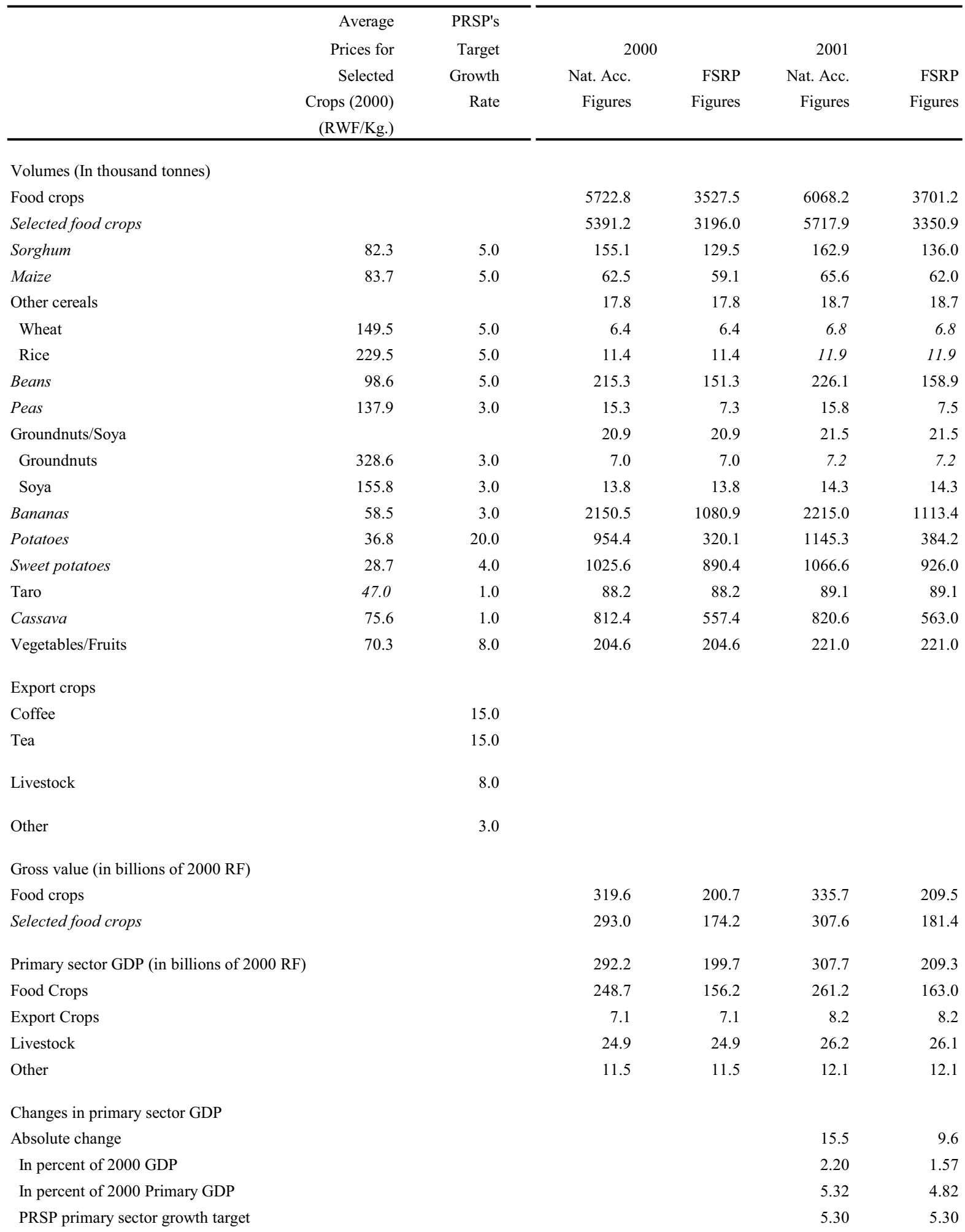

Source: FSRP, PRSP, Rwandan authorities and authors' calculations 
11.

Using this information, estimations of gross value, input cost and value added for the primary sector are calculated in order to check whether or not the target growth rate of 5.3 percent for the primary sector is internally consistent, i.e., if it can be derived by using the particular target growth rates assumed on the 2000 values of each component of the primary sector GDP according to the National Account statistics. While this target rate is, in effect, internally consistent, when calculations are performed using the information contained in national accounts (GoR (2002a)), it is not when FSRP figures are used instead. ${ }^{9,10,11}$

\section{The reason behind this difference is that production figures in MINAGRI/FSRP} (2001) are substantially smaller than those published in GoR (2002a), and so is the relative composition among subsectors (and food crops). Therefore, when applying the target growth rates for the specific subsectors (and crops) assumed in the PRSP, the primary sector rate of growth in 2001 is reduced to 4.8 percent, i.e., 0.5 percentage points lower than targeted. ${ }^{12,13}$

13. Which of the data sets is most reliable? Which data should be used in reviewing the viability of the growth strategy and its projected poverty impact? Insufficient resources and a difficult political situation motivated the disruption of the agricultural surveys in 1991, as mentioned above. In the absence of better ways (or to avoid a painful downward revision of GDP figures), the Ministry of Agriculture based (and continues to base) its estimations of

\footnotetext{
${ }^{9}$ If, however, the target growth rates are assumed to last for more than a year, the increase in the importance of those crops for which higher rates of growth are assumed, most notably Irish potatoes, begin to dominate and push the rate of growth of agricultural -and primary- GDP up to 9.5 and 8.3 percent in 2006, if GoR(2002a) or MINAGRI/FSRP figures are used, respectively.

${ }^{10}$ The PRSP and its supporting documents use the year 2000 as their base; to preserve analytical clarity, the paper will use the same base. This will be useful later on to compare actual with forecast figures in the PRSP.

${ }^{11}$ The difficulties encountered in arriving at a consistent time series estimate for Rwanda's agriculture output are extraordinary: “... MINAGRI ..., did not reinstate an agricultural census based on a nationally representative random sample of farmers until the beginning of the 2000A season" (Kelly et al (2001a)). The previous survey conducted by MINAGRI, during 1991, i.e., MINAGRI /FSRP (2001) was, actually, the first survey of agricultural production in ten years.
}

\footnotetext{
${ }^{12}$ This difference is mostly the consequence of different production figures for Irish potatoes ( 950 thousand tones according to GoR (2002a) and only 320 thousand tones according to MINAGRI/FSRP (2001). Goosens (2002) is aware of the differences in figures for the production of Irish potatoes. He also mentions a third source of information, also inconsistent with the first two. Mellor (2002a) explicitly uses official national accounts statistics to obtain its target growth rate for the primary sector and also, for his estimation of the composition of GDP between tradable and not tradable goods production (both in the rural and non-rural sectors). However, when analyzing the regional market for Irish potatoes, he uses FAO figures, which are inconsistent with national account statistics and seem to be in line with the figures reported in MINAGRI/FSRP (2001).
}

\footnotetext{
${ }^{13}$ MINAGRI/FSRP (2001) does not include information for the production of groundnuts, soya, taro and vegetables and fruits. Given their limited importance for total agricultural production, their levels were assumed to be equal to those reported in GoR (2002a). Additionally, MINAGRI/FSRP (2001) does not report production figures for export crops; however, production figures for these crops can be assessed from external trade accounts and also from information by OCIR-Café and OCIR-Thé (the public entities involved in coffee and tea distribution). We assumed that the figures reported in GoR (2002a) were accurate.
} 
agricultural production on informal surveys of surfaces planted per crop, per province. However, the Ministry of Agriculture does not run ex-post checks on how accurate these exante estimations were. The FSRP surveys did exactly that, providing production figures based on a nationally representative random sample, not just ex-ante estimations. Given this, the FSRP data would seem to be the most appropriate basis for measuring agricultural production.

14. Basing the analysis of the growth strategy on the FRSP data leads to three important changes. First, since agricultural production is lower than that included in national account statistics, the growth base will differ from that used in the PRSP. Second, FSRP surveys were conducted only for the period 2000-02 whereas the national accounts continuously overstated estimations of agricultural Third, the overall assessment of poverty in Rwanda, including food security, could be worse than has been actually assessed in the PRSP. ${ }^{14}$

\section{Data inconsistencies: GoR vs. FSRP/Ministry of Agriculture}

15. Table 2 compares selected food crop production for 2000-02 (and gross value of production for 2000) contained in the national account statistics with the surveys conducted by the Ministry of Agriculture. In volume terms, 2000 Ministry of Agriculture totals represent just over 59 percent of those published by the GoR (2002a). For 2001 this ratio falls to 57 percent and jumps to around 70 percent for $2002 .{ }^{15}$ Obviously, these differences are substantial enough to influence the assessment of food security in Rwanda.

16. Finally, as already emphasized (see Table 1), these differences affect the gross value of production for the selected crops included in the Ministry of Agriculture survey. For example, in 2000 the value of production according to the Ministry of Agriculture survey would be over 59 percent of the gross value of production reported by the national accounts.

\footnotetext{
${ }^{14}$ A recent technical assistance mission from East AFRITAC confirmed this methodological problem.

${ }^{15}$ The largest differences were found for Irish potatoes and bananas.
} 
Table I.2. Differences in Agricultural Production Data (In thousand tonnes)

\begin{tabular}{|c|c|c|c|c|c|c|c|c|c|}
\hline & \multicolumn{2}{|c|}{2000} & \multicolumn{2}{|c|}{2001} & \multicolumn{2}{|c|}{2002} & 2000 & 2001 & 2002 \\
\hline & $\begin{array}{c}\text { National } \\
\text { Accounts } \\
\text { (A) }\end{array}$ & $\begin{array}{c}\text { FSRP } \\
\text { Figures } \\
\text { (B ) }\end{array}$ & $\begin{array}{l}\text { National } \\
\text { Accounts } \\
\text { (C) }\end{array}$ & $\begin{array}{r}\text { FSRP } \\
\text { (D) }\end{array}$ & $\begin{array}{c}\text { National } \\
\text { Accounts } \\
\text { (E) }\end{array}$ & $\begin{array}{l}\text { FSRP } \\
(\mathrm{F})\end{array}$ & $\begin{array}{c}(\mathrm{B}) /(\mathrm{A}) \\
(\%)\end{array}$ & $\begin{array}{c}(\mathrm{D}) /(\mathrm{C}) \\
(\%)\end{array}$ & $\begin{array}{c}(\mathrm{F}) /(\mathrm{E}) \\
(\%)\end{array}$ \\
\hline $\begin{array}{l}\text { Selected food crop production } \\
\text { (In percent of total food crop production) }\end{array}$ & $\begin{array}{r}5391.2 \\
94.2\end{array}$ & 3196.0 & $\begin{array}{r}4958.8 \\
93.6\end{array}$ & 2832.5 & $\begin{array}{r}6685.4 \\
94.2\end{array}$ & 4845.1 & 59.3 & 57.1 & 72.5 \\
\hline Sorghum & 155.1 & 129.5 & 174.9 & 108.7 & 184.3 & 148.0 & 83.5 & 62.1 & 80.3 \\
\hline Maize & 62.5 & 59.1 & 92.1 & 92.5 & 91.7 & 113.4 & 94.5 & 100.4 & 123.7 \\
\hline Beans & 215.3 & 151.3 & 290.0 & 194.7 & 246.8 & 218.8 & 70.3 & 67.1 & 88.6 \\
\hline Peas & 15.3 & 7.3 & 15.5 & 8.8 & 16.0 & 12.8 & 47.6 & 56.8 & 79.9 \\
\hline Bananas & 2150.5 & 1080.9 & 1572.7 & 858.0 & 2784.9 & 2024.6 & 50.3 & 54.6 & 72.7 \\
\hline Potatoes & 954.4 & 320.1 & 971.3 & 400.3 & 1038.9 & 432.3 & 33.5 & 41.2 & 41.6 \\
\hline Sweet potatoes & 1025.6 & 890.4 & 1154.3 & 725.3 & 1291.8 & 1201.1 & 86.8 & 62.8 & 93.0 \\
\hline Cassava & 812.4 & 557.4 & 688.0 & 444.2 & 1031.1 & 694.1 & 68.6 & 64.6 & 67.3 \\
\hline
\end{tabular}

Source: FSRP, Rwandan Authorities and authors' calculations

Table 3 shows yields per hectare for selected crops for 2000-02. As expected, yields per hectare according to the Ministry of Agriculture are substantially lower than those reported by the national accounts. ${ }^{16}$ As we show later, the differences in yields arise mainly from differences in the volumes produced, although variations in land under cultivation for individual crops also played a role. The total area cultivated as, reported by both sources, was fairly similar, however.

Table I.3. Yields per Type of Crop (In tonnes)

\begin{tabular}{|c|c|c|c|c|c|c|c|c|c|}
\hline & $\begin{array}{c}2000 \\
\text { National } \\
\text { Accounts } \\
\text { (A ) }\end{array}$ & $\begin{array}{l}\text { FSRP } \\
\text { (B) }\end{array}$ & $\begin{array}{c}2001 \\
\text { National } \\
\text { Accounts } \\
\text { ( C ) }\end{array}$ & $\begin{array}{l}\text { FSRP } \\
\text { (D) }\end{array}$ & $\begin{array}{c}2002 \\
\text { National } \\
\text { Accounts } \\
\text { (E) }\end{array}$ & $\begin{array}{l}\text { FSRP } \\
(\mathrm{F})\end{array}$ & $\begin{array}{c}2000 \\
(\mathrm{~B}) /(\mathrm{A}) \\
(\%)\end{array}$ & $\begin{array}{c}2001 \\
(\mathrm{D}) /(\mathrm{C}) \\
(\%)\end{array}$ & $\begin{array}{c}2002 \\
(F) /(E) \\
(\%) \\
\end{array}$ \\
\hline Sorghum & 0.89 & 0.68 & 1.07 & 0.71 & 1.12 & 0.90 & 76.8 & 66.5 & 79.7 \\
\hline Maize & 0.70 & 0.66 & 0.82 & 0.73 & 0.81 & 0.92 & 94.5 & 88.8 & 112.8 \\
\hline Beans & 0.65 & 0.49 & 0.76 & 0.56 & 0.64 & 0.68 & 75.1 & 73.4 & 105.4 \\
\hline Peas & 0.51 & 0.30 & 0.49 & 0.28 & 0.51 & 0.38 & 58.7 & 56.5 & 75.1 \\
\hline Bananas & 5.97 & 2.94 & 4.40 & 2.60 & 7.76 & 5.61 & 49.3 & 59.1 & 72.3 \\
\hline Potatoes & 8.76 & 4.09 & 8.16 & 3.49 & 8.68 & 4.50 & 46.8 & 42.8 & 51.8 \\
\hline Sweet Potatoes & 5.87 & 4.93 & 6.00 & 4.02 & 6.69 & 6.06 & 83.9 & 67.0 & 90.6 \\
\hline Cassava & 6.74 & 2.35 & 5.41 & 1.88 & 8.07 & 2.68 & 34.8 & 34.8 & 33.2 \\
\hline
\end{tabular}

Source: FSRP, Rwandan authorities and authors' calculations

In Table 4 we estimate (from Tables 2 and 3 ) how national accounts would have been affected in 2000 if actual production figures had been used. Such estimation is based on a calculation of gross value of production using average market prices for food crops and an assessment of the input cost ratio, using gross value and value added as reported in GoR

\footnotetext{
${ }^{16}$ This is especially the case for cassava, Irish potatoes, bananas and peas.
} 
(2002a) ${ }^{17}$ Combining this ratio with the gross value of selected crops contained in MINAGRI/FSRP (2001), we estimated a new value of GDP for food crops. Throughout, the value added for the food crops not included in the MINAGRI/FSRP survey was assumed to be equal to that reported in the national accounts.

Table I.4. Rwanda: National Accounts According to Different Official Sources

(In billions of RF unless otherwise indicated)

\begin{tabular}{|c|c|c|c|c|}
\hline & $\begin{array}{c}2000 \\
\text { National } \\
\text { Accounts } \\
\text { (A) }\end{array}$ & $\begin{array}{l}\text { FSRP } \\
\text { (B) }\end{array}$ & (B) $-(\mathrm{A})$ & $(\mathrm{B}) /(\mathrm{A})$ \\
\hline GDP (Factor cost) & 658.9 & 566.4 & -92.5 & 86.0 \\
\hline Primary sector & 292.2 & 199.7 & -92.5 & 68.3 \\
\hline of which food crops & 248.7 & 156.2 & -92.5 & 62.8 \\
\hline GDP (Market prices) & 705.7 & 613.2 & -92.5 & 86.9 \\
\hline Consumption & 695.6 & 603.1 & -92.5 & 86.7 \\
\hline of which private (residual) & 621.3 & 528.8 & -92.5 & 85.1 \\
\hline \multicolumn{5}{|l|}{ For memoradum } \\
\hline $\mathrm{RF} / \mathrm{USD}$ exchange rate (period average) & 389.7 & 389.7 & & \\
\hline GDP (millions current dollars) & 1810.9 & 1573.6 & -237.3 & 86.9 \\
\hline Population (millions) & 8.5 & 8.5 & & \\
\hline Per capita GDP (US dollars) & 213.0 & 185.1 & -27.9 & 86.9 \\
\hline
\end{tabular}

Source: FSRP, Rwandan authorities and authors' calculations

17. The results of these calculations indicate that if the production figures reported in MINAGRI/FSRP (2001) were used to compute the national accounts, the GDP at current prices for the year 2000 would be about 13 percent lower than that reported in the official national accounts. Primary sector GDP would be 32 percent and private consumption 15 percent lower than those reported in the national account statistics. ${ }^{18}$ As a result, the primary sector would account for 35 percent of GDP compared to 44 percent of GDP under the official national accounts measure. It is worth noting that the size of the primary sector GDP is a key factor in the poverty reduction strategy as described in the PRSP. Non-farm

\footnotetext{
${ }^{17}$ For bananas, a simple average of prices for banana à cuire and banana fruit was used; for vegetables, the average price was calculated as a simple average of vegetable prices as reported in PRSP.

${ }^{18}$ On the demand side, we assumed that all of the decrease in the value of GDP generated would depress private consumption.
} 
economic growth is assumed to be driven by rural farm income. The smaller is the size of the primary sector, the larger must be the elasticity to obtain gains in rural non-farm income. ${ }^{19}$

\section{Measuring potential increases in agricultural production: a simple methodology}

18. In order to estimate potential increases in agricultural production, the following methodology can be used. Yields $y_{i j}^{\rho}$ per hectare of soil $j$, in province $\rho$, for crop $i$ can be defined as

(1) $y_{i j}^{\rho}=f_{i j}(\phi, v \cdot l, \vartheta \cdot s, k ; \Theta) \cdot \varepsilon$,

where $\phi$ denotes the level of fertilization, $l$ is labor input ( $v$ accounting for quality of labor), $s$ denotes the seed input ( $\vartheta$ accounting for quality of seeds), $k$ is the level of physical capital, and $\Theta$ is a generic variable that accounts for elements difficult to measure, e.g., the influence of land tenure. $\varepsilon$ is a random variable, with $E \varepsilon=1$ and strictly positive variance, which captures the uncertainties associated with agricultural production, most notably weather developments. ${ }^{20}$ In the economically relevant region, $f_{i j \phi}, f_{i j v \cdot l}, f_{i j \vartheta \cdot s}, f_{i j k}>0$. The same production function holds for all provinces provided that the same type of crop and soil are being considered. Furthermore,

(2) $\phi=\min \left[\alpha_{i} \cdot x_{1}, \gamma_{i} \cdot x_{2}\right]$,

where $\phi$ is defined as a Leontief function (with $\alpha_{i}>0$ and $\gamma_{i}>0$ ), with inputs of inorganic (chemical) fertilizer $x_{1}$, and organic (manure) fertilizer, $x_{2}$. The Leontief technology captures the fixity with which the organic and inorganic fertilizers must be used in order to assure efficiency. For simplicity, the function includes only one (generic) type of inorganic fertilizer.

Production of crop $i$, in province $\rho$, is given by

(3) $Y_{i}^{\rho}=S^{\rho} \cdot \sum_{j=1}^{J} \theta_{j}^{\rho} \cdot \lambda_{i j}^{\rho} \cdot y_{i j}^{\rho}$,

\footnotetext{
${ }^{19}$ Input costs are probably overestimated because they are measured by market prices instead of farm prices. In the case of export crops, farm (producer) prices were used. Finally, note that these figures imply a per capita GDP of US\$185 per year compared to the official figure of US\$213 for 2000.

${ }^{20}$ Clay (1996) and Clay and others (2001) are useful references on the determinants of agricultural production in Rwanda.
} 
where $S^{\rho}$ denotes total (arable) surface in use in hectares in province $\rho, \theta_{j}^{\rho}$ is the proportion of that surface accounted for by soil of type $j$ in province $\rho$, and $\lambda_{i j}^{\rho}$ denotes the proportion of soil $j$ cultivated with crop $i$ in province $\rho$. With $J$ denoting the number of different types of soil, $\sum_{j=1}^{J} \theta_{j}^{\rho}=1$. The total national production of crop $i$ is given by

(4) $Y_{i}=\sum_{\rho=1}^{\mathrm{P}} Y_{i}^{\rho}$,

where $\mathrm{P}$ denotes the number of provinces in the country. ${ }^{21}$

19. If data on fertilizer response per type of crop and soil are available, and assuming other inputs can be replicated in real conditions, it is possible to obtain a measure of (total) potential agricultural production. Subsumed in this exercise are data on type of soil per province, and cultivated land per type of crop, soil and province. ${ }^{22}$ The relationship allows for assessment of potential increases in agricultural production given changes in fertilizer intensification.

20. Rwanda is divided into eighteen different agro bioclimatic (ABC) zones (which determine soil qualities) and twelve provinces. Land is cultivated in all provinces except Kigali-Ville (i.e. $J=18$ and $\mathrm{P}=11$ ). Berdinger (1993), based on earlier work by J. Gasana on $\mathrm{ABC}$ zones, estimated a division of each province into these different zones, i.e., he provided the values of $\theta_{j}^{\rho}, \forall j, \rho{ }^{23}$ In addition, Kelly and Murekezi (2000) provided information about fertilizer response for a number of food crops using NPK or combinations of Urea and DAP in the presence of appropriate amounts of organic fertilizer. ${ }^{24}$ The trials are

\footnotetext{
${ }^{21}$ Note that in (3), $S^{\rho}$ could be lower than the total arable surface. In Rwanda, total arable land is estimated at 1,114 thousand hectares. According to 2002 figures from the MINAGRI/FSRP survey, approximately 900 thousand hectares were cultivated in each of Season A and B (slightly more than 80 percent of the total).

${ }^{22}$ These are strong assumptions. If anything, they introduce an upside bias to the results. The measure of potential output as described above is not necessarily associated with any optimal behavior of agents. It just reflects a technical relationship.

${ }^{23}$ Note that we have implicitly assumed the composition of land under cultivation per type of soil to be uniform across the country.

${ }^{24}$ The crops covered in Kelly and Murekezi (2000) are climbing beans, maize, rice, sorghum, Irish potatoes, soybeans, sweet potatoes and cabbage. Additionally, they reported that for the $\mathrm{ABC}$ zones where fertilizer trials had been conducted for cassava, wheat and peas, profitability was not assured. To the best of our knowledge no fertilizer trials have been carried out for bananas, coffee and tea. This gap is significant since bananas are the single most important crop while coffee and tea make up most of Rwanda's exports. Desai (2002) reports that OCIR-Café and OCIR-Thé have estimated potential demand for inorganic fertilizer but does not explain the methodology. Murekezi in Abt associates (2002) mentions some estimates for yields associated with fertilizer utilization for tea cultivation but not for coffee.
} 
relevant because they provide information about $f_{i j}(\cdot), \alpha_{i}$ and $\gamma_{i}$. An assumption of their replicability is key to estimating potential agricultural production. Finally, the allocation of land per type of crop for each province may be obtained from either GoR (2002a) or MINAGRI/FSRP (2001). We will use both for comparability purposes.

21. Note that the existing information is insufficient to determine the values of $\lambda_{i j}^{\rho}, \forall i, j, \rho$. To fill this gap, we assumed that each crop is cultivated in different types of soil in proportions that are identical to proportions of different $\mathrm{ABC}$ zones for the entire province.

22. It is possible now to extend this simple methodology to the entire agricultural sector. Table 5 provides data on total potential additional production for selected food crops. Given cultivated land per crop, soil and province, we applied the recommended profitable doses of both organic and inorganic fertilizer as reported in Kelly and Murekezi (2000). ${ }^{25}$

\footnotetext{
${ }^{25}$ Fertilizer profitability is analyzed in Kelly and Murekezi (2000) using V/C ratios for 1999. A V/C ratio greater than one is considered to be profitable from an economic perspective. This introduces an efficiency measure into an otherwise technical calculation. We have no knowledge of these $\mathrm{V} / \mathrm{C}$ ratios being extended beyond 1999. Also, many of the fertilizer trials include both NPK and combinations of DAP and Urea. Since the combinations of DAP and Urea are usually more effective, we have computed potential production and fertilizer response using this combination. However, in reality NPK application continues to predominate, as pointed out by Murekezi in Abt associates (2002).
} 
Table I.5. Rwanda: Estimation of Potential Additional Production Derived from Optimal Fertilizer Utlization

Figures According to National Accounts

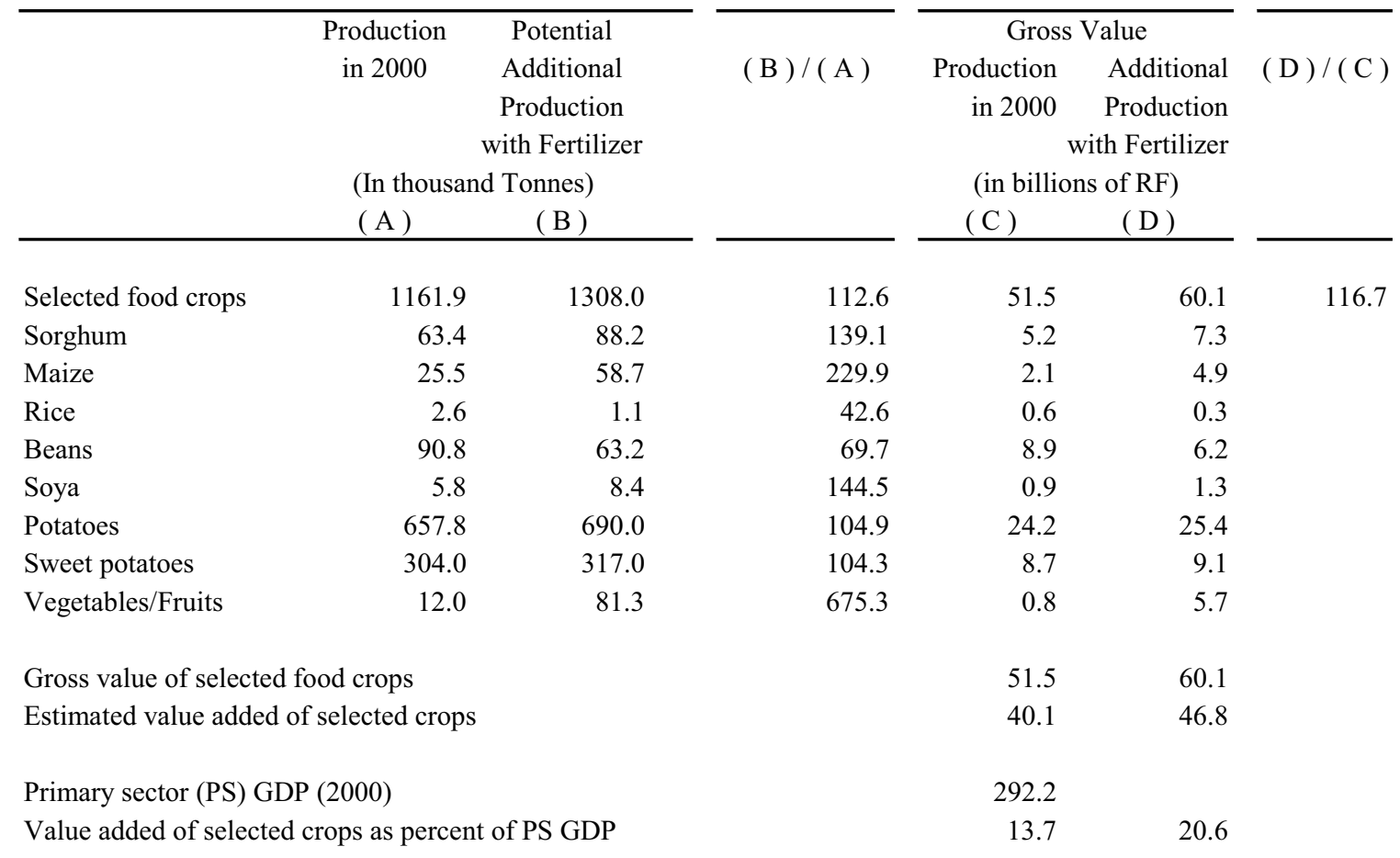

Figures According to FSRP

\begin{tabular}{cc}
\hline Production & Potential \\
in 2000 & Additional \\
Production \\
with Fertilizer \\
(In thousand tonnes) \\
(A) & (B) \\
\hline
\end{tabular}

Selected food crops

Sorghum

Maize

Rice

Beans

Soya

Potatoes

Sweet potatoes

Vegetables/Fruits

$\begin{array}{rr}578.2 & 1023.3 \\ 44.4 & 101.6 \\ 19.1 & 50.0 \\ & \\ 65.8 & 79.9 \\ & \\ 223.0 & 512.5 \\ 225.9 & 279.2 \\ 12.0 & 28.3\end{array}$

Gross value of selected food crops

Estimated value added of selected crops

Estimated primary sector GDP (2000)

Value added of selected crops as percent of PS GDP

\begin{tabular}{|c|c|c|c|}
\hline \multirow[t]{2}{*}{ (B ) / ( A ) } & $\begin{array}{l}\text { Gross Value } \\
\text { Production } \\
\text { in } 2000 \\
\quad \text { (in billic }\end{array}$ & $\begin{array}{l}\text { Additional } \\
\text { Production } \\
\text { with Fertilizer } \\
\text { ons of RF) }\end{array}$ & \multirow[t]{2}{*}{$(\mathrm{D}) /(\mathrm{C})$} \\
\hline & ( C ) & (D) & \\
\hline 177.0 & 26.4 & 47.3 & 179.0 \\
\hline 228.9 & 3.7 & 8.4 & \\
\hline \multirow[t]{2}{*}{261.4} & 1.6 & 4.2 & \\
\hline & 0.0 & 0.0 & \\
\hline \multirow[t]{2}{*}{121.5} & 6.5 & 7.9 & \\
\hline & 0.0 & 0.0 & \\
\hline 229.8 & 8.2 & 18.8 & \\
\hline 123.6 & 6.5 & 8.0 & \\
\hline \multirow[t]{5}{*}{235.2} & 0.8 & 2.0 & \\
\hline & 26.4 & 47.3 & \\
\hline & 20.6 & 36.8 & \\
\hline & 199.7 & & \\
\hline & 10.3 & 23.7 & \\
\hline
\end{tabular}

Source: FSRP, Rwandan authorities and authors' calculations 
23. Although the same yield responses are applied, the potential increases in crop output will differ depending on which data on cultivated land per type of crop and province are applied (GoR (2002a) vs. MINAGRI/FSRP (2001). The two sources simply supply inconsistent information about cultivated land per crop per province.

24. Despite its simplicity this methodology is flexible. It has the added relevance of being singled out in the PRSP as the engine of agricultural development in Rwanda. Indeed, Mellor (2002a) assumed that 75 percent of growth of the primary sector GDP can be explained by increases in fertilizer utilization. ${ }^{26}$

25. The upper part of Table 5 reports the results for potential production gains using the cultivated land per crop as reported in GoR (2002a). Based on these figures, output of selected food crops could be approximately doubled if recommended doses of fertilizer are used. The lower part of Table 5 shows the respective results when applying the data from MINAGRI/FSRP (2001). Following to this latter approach, production of selected food crops could be almost tripled.

26. Although fertilizer intensification would add to the volume of crops it would add less to the value of primary sector GDP. Given the PRSP's long-term horizon (and the document's consistency with Vision 2020), it is relevant to estimate how sustainable is the 5.3 per cent target growth rate for the primary sector. Regardless of sources of data, such a rate of growth could not be maintained beyond three to four years.

27. Finally, it is important to stress that this analysis is static in nature, i.e., it does not take into consideration the effects of additional production on prices. Changes in relative supplies could affect relative prices, $\mathrm{V} / \mathrm{C}$ ratios, and incentives for fertilizer utilization as well as allocation of land for agricultural and non-agricultural purposes. ${ }^{27}$

\section{The agroeconomic potential}

28. For clarity purposes it is important to introduce a concept of agroeconomic potential as specified by theoretical demand for fertilizer. It is defined as the amount of fertilizer consumed which maximizes profits. Basic economic theory teaches us that fertilizer is profitably demanded when its additional cost is more than compensated by the incremental value it generates. This holds for $\mathrm{V} / \mathrm{C}$ ratios greater than one. At any given time the agroeconomic potential is derived by multiplying the land used (in ha) by the recommended

\footnotetext{
${ }^{26}$ See Mellor (2002a) page 7, and PRSP page 30. It is not clear if the reference is to the primary sector as a whole, to food crops only, or to a combination of food and export crops.

${ }^{27}$ In other words, in a fully specified model, $x_{1}, x_{2}, s, l, k, \lambda_{i j}^{\rho}$ and prices of each crop $i$ are endogenous and so are $\mathrm{V} / \mathrm{C}$ ratios per crop. Static exercises, such the ones performed in this paper and in the PRSP, are useful for short-term analysis. Their utility is drastically reduced for longer horizons, where marketing constraints bind. Given current restrictions and uncertainties associated with the Rwandan data sets, such models would be difficult to design and test.
} 
fertilizer doses per crop for $\mathrm{V} / \mathrm{C}$ ratios greater than one. ${ }^{28}$ The estimates of the potential are computed in Table 6 using information from Kelly and Murekezi (2000) for both the GoR (2002a) and the MINAGRI/FSRP (2001) data sets. The first set of columns reports the estimates for selected crops using the sources already mentioned.

29. The second set of columns shows the additional demand for inorganic fertilizer per crop that could be justified on efficiency grounds. These calculations depict the demand for inorganic fertilizer for $\mathrm{V} / \mathrm{C}$ ratios greater than two, as reported in Kelly and Murekezi $(2000){ }^{29}$

30. It also includes the average recommended doses of organic fertilizer that are needed for inorganic fertilizer to be effective. The third set of columns contains an estimation of the current level of fertilizer use per type of food crop. Note the very low level of utilization compared with the ex-ante potential demand. The fourth set of columns approximates the cultivated area for which economically profitable fertilizer trials were in place. This figure, at 25 percent, indicates that more fertilizer trials could be applied for the main ABC zones and crops, as pointed out in Kelly and Murekezi (2000) and Kelly et al (2001b). The fifth set of columns documents fertilizer productivity indicators per type of food crop, measured by marginal physical product. ${ }^{30}$ Finally, the sixth set of columns shows the current composition of fertilizer utilization. ${ }^{31}$

\footnotetext{
${ }^{28}$ Kelly et al (2001b) estimated the agro-economic potential for fertilizer using a similar methodology, but took into consideration only those crops for which $\mathrm{V} / \mathrm{C}>3$.

${ }^{29}$ A ratio of $\mathrm{VC}>2$ was chosen as a threshold for two reasons. First, it allows us to analyze the proposed schedule of fertilizer increases using those combinations of crop/ABC zone/province for which the response is known to be important. Second, due to doubtful quality of data, we want to constrain the $\mathrm{V} / \mathrm{C}$ ratio to be greater than one.

${ }^{30}$ As can be seen, the crops most responsive to inorganic fertilizer are Irish potatoes and vegetables. Consequently, Irish potatoes command most of the inorganic fertilizer application.

${ }^{31}$ See Mellor (2002a) page 11. Mellor also estimates potential production gains for coffee and tea resulting from increases in hypothetical application of inorganic fertilizer. He points out, based on a personal observation, that despite production reaching by 1999 a third of its pre-war level, "... in Butare and elsewhere new plantings are going in at a rapid rate." Loveridge (2002) has an alternative view. Consistent with Mellor (2002a), he points out that "substantial percentages of producers have stopped growing coffee in recent years" but "[m]ore are considering changes that will place emphasis on alternative crops, notably bananas and beans. A small price decrease from 2001 prices will bring even more coffee growers to the (point) where they stop tending their coffee."
} 
Table I.6. Rwanda: Agroeconomic Potential and Marginal Physical Product of Fertilizer for Selected Crops Using 2000 as Base Year

\begin{tabular}{|c|c|c|c|c|c|c|c|c|c|c|c|c|}
\hline & \multicolumn{2}{|c|}{$\begin{array}{c}2000 \\
\text { Agroeconomic } \\
\text { Potential (V/C }>1,1999) \\
(, 000 \text { tonnes })\end{array}$} & \multicolumn{2}{|c|}{$\begin{array}{c}2000 \\
\text { Agroeconomic } \\
\text { Potential }(\mathrm{V} / \mathrm{C}>2,1999) \\
(, 000 \text { tonnes })\end{array}$} & \multicolumn{2}{|c|}{$\begin{array}{c}2000 \\
\text { Current } \\
\text { Utilization } \\
(, 000 \text { tonnes })\end{array}$} & \multirow{2}{*}{\multicolumn{2}{|c|}{$\begin{array}{c}2000 \\
\% \text { of Cultivated } \\
\text { Area Included } \\
\text { in Calculation }\end{array}$}} & \multirow{2}{*}{\multicolumn{2}{|c|}{$\begin{array}{c}2000 \\
\text { Estimated MPP of } \\
\text { Fertilizer } \\
\text { Extra Tonnes per } \\
\text {,000 extra Fertilizer } \\
\text { Utilization } \\
\text { (A) }\end{array}$}} & \multicolumn{2}{|c|}{$\begin{array}{c}2000 \\
\text { Estimated MPP of } \\
\text { Fertilizer } \\
\text { Extra Tonnes per } \\
\text {,000 extra Fertilizer } \\
\text { utilization }\end{array}$} \\
\hline & (A) & (B) & (A) & (B) & (A) & (B) & & & & & (A) & (B) \\
\hline $\begin{array}{l}\text { Total fertilizer } \\
\text { Inorganic } \\
\text { Organic }\end{array}$ & 80.91 & 75.11 & $\begin{array}{r}79.33 \\
1416.80\end{array}$ & $\begin{array}{r}73.44 \\
1352.25\end{array}$ & 1.59 & 1.68 & 26.2 & 24.0 & & & & \\
\hline $\begin{array}{l}\text { Sorghum } \\
\text { Inorganic } \\
\text { Organic } \\
\text { Maize }\end{array}$ & 12.29 & 14.44 & $\begin{array}{r}12.04 \\
294.21\end{array}$ & $\begin{array}{r}14.39 \\
355.54\end{array}$ & 0.25 & 0.05 & 42.2 & 46.5 & 7.3 & 7.1 & 15.6 & 2.8 \\
\hline $\begin{array}{l}\text { Inorganic } \\
\text { Organic } \\
\text { Rice }\end{array}$ & 7.19 & 7.36 & $\begin{array}{r}7.18 \\
153.89\end{array}$ & $\begin{array}{r}7.36 \\
145.77\end{array}$ & 0.01 & 0.00 & 42.9 & 34.3 & 8.2 & 6.8 & 0.3 & 0.3 \\
\hline $\begin{array}{l}\text { Inorganic } \\
\text { Organic } \\
\text { Beans }\end{array}$ & 0.16 & 0.03 & $\begin{array}{l}0.11 \\
3.06\end{array}$ & $\begin{array}{l}0.02 \\
0.68\end{array}$ & 0.05 & 0.01 & 17.9 & 3.1 & 10.2 & & 3.1 & 0.5 \\
\hline $\begin{array}{l}\text { Inorganic } \\
\text { Organic } \\
\text { Soya }\end{array}$ & 17.30 & 16.46 & $\begin{array}{r}17.23 \\
533.90\end{array}$ & $\begin{array}{r}16.39 \\
516.11\end{array}$ & 0.07 & 0.07 & 45.8 & 47.3 & 3.7 & 4.9 & 4.4 & 4.2 \\
\hline $\begin{array}{l}\text { Inorganic } \\
\text { Organic } \\
\text { Potatoes }\end{array}$ & 1.62 & 0.49 & $\begin{array}{r}1.61 \\
28.99\end{array}$ & $\begin{array}{r}0.48 \\
13.95\end{array}$ & 0.00 & 0.01 & 39.2 & 32.2 & 5.2 & & 0.3 & 0.3 \\
\hline $\begin{array}{l}\text { Inorganic } \\
\text { Organic } \\
\text { Sweet potatoes }\end{array}$ & 18.40 & 14.56 & $\begin{array}{r}17.24 \\
179.37\end{array}$ & $\begin{array}{r}13.07 \\
130.90\end{array}$ & 1.16 & 1.49 & 65.8 & 67.0 & 40.0 & 39.2 & 73.3 & 88.9 \\
\hline $\begin{array}{l}\text { Inorganic } \\
\text { Organic } \\
\text { Vegetables/Fruits }\end{array}$ & 23.11 & 21.46 & $\begin{array}{r}23.08 \\
201.84\end{array}$ & $\begin{array}{r}21.43 \\
181.78\end{array}$ & 0.03 & 0.03 & 29.7 & 25.9 & 13.7 & 13.0 & 1.9 & 1.5 \\
\hline $\begin{array}{l}\text { Inorganic } \\
\text { Organic }\end{array}$ & 0.85 & 0.32 & $\begin{array}{r}0.83 \\
21.55\end{array}$ & $\begin{array}{l}0.29 \\
7.51\end{array}$ & 0.02 & 0.03 & 6.9 & 8.0 & 97.6 & 97.6 & 1.0 & 1.5 \\
\hline
\end{tabular}

Source: FSRP, Rwandan authorities and authors' calculations

Notes: (A) National Accounts; (B) FSRP 


\section{Proposed fertilizer intensification and growth targets}

31. It is possible now to make an assessment of the consistency between the target growth rates and fertilizer intensification proposed in the PRSP and its supporting documents. To assess such consistency, the target increases in fertilizer included in the PRSP are combined with the data reported in Table 6 . The results are reported in Tables 7 and 9 for GoR (2002a) data sets and in Tables 8 and 10 for MINAGRI/FSRP (2001) data sets.

32. Since the PRSP does not specify how increases in fertilizer utilization are to be allocated among different crops, Tables 7 and 8 approximate this allocation to that reported by Mellor (2002a). Mellor assumes that coffee and tea are strongly fertilized (relative to other crops). This is backed by data regarding current fertilizer consumption. However, it is important to point out that no published results are available with respect to yield response of these crops to inorganic fertilizer.

33. Tables 9 and 10 calculate increases in hypothetical agricultural production, both in volume and in 2000 Rwandan francs (RWF), if fertilizer had been applied as reported in Tables 7 and 8. Again, the estimates depend on the choice of official sources. The first part of the tables shows increases in volumes and the second part increases in value. 
Table I.7. Rwanda: Proposed Schedule for Fertilizer Intensification and Associated Production Increases (For selected Crops. Figures According with National Accounts Figures)

\begin{tabular}{|c|c|c|c|c|c|c|c|c|}
\hline & 2000 & 2001 & 2002 & 2003 & 2004 & 2005 & 2006 & $\begin{array}{c}\text { Agroeconomic } \\
\text { Potential } \\
\end{array}$ \\
\hline \multirow{3}{*}{$\begin{array}{l}\text { Food and Export Crops } \\
\text { annual changes }\end{array}$} & 2.94 & 4.94 & 7.94 & 12.94 & 17.95 & 22.94 & 27.94 & \\
\hline & & 2.00 & 3.00 & 5.00 & 5.00 & 5.00 & 5.00 & \\
\hline & & 2.00 & 3.00 & 5.00 & 5.00 & 5.00 & 5.00 & \\
\hline Sorghum & 0.25 & 0.27 & 0.46 & 0.84 & 1.39 & 1.86 & 2.29 & 12.29 \\
\hline annual changes & & 0.03 & 0.18 & 0.38 & 0.55 & 0.47 & 0.44 & \\
\hline Maize & 0.01 & 0.06 & 0.24 & 0.62 & 1.17 & 1.63 & 2.16 & 7.19 \\
\hline annual changes & & 0.05 & 0.18 & 0.38 & 0.55 & 0.46 & 0.53 & \\
\hline Rice & 0.05 & 0.16 & 0.16 & 0.16 & 0.16 & 0.16 & 0.16 & 0.16 \\
\hline annual changes & & 0.11 & 0.00 & 0.00 & 0.00 & 0.00 & 0.00 & \\
\hline Beans & 0.07 & 0.12 & 0.30 & 0.68 & 1.23 & 1.69 & 2.13 & 17.30 \\
\hline annual changes & & 0.05 & 0.18 & 0.38 & 0.55 & 0.46 & 0.44 & \\
\hline Soya & 0.00 & 0.06 & 0.24 & 0.62 & 1.17 & 1.62 & 1.62 & 1.62 \\
\hline annual changes & & 0.05 & 0.18 & 0.38 & 0.55 & 0.45 & 0.00 & \\
\hline Potatoes & 1.16 & 1.96 & 3.06 & 5.06 & 6.06 & 7.31 & 8.81 & 18.40 \\
\hline annual changes & & 0.80 & 1.10 & 2.00 & 1.00 & 1.25 & 1.50 & \\
\hline Sweet Potatoes & 0.03 & 0.08 & 0.26 & 0.64 & 1.19 & 1.65 & 2.09 & 23.11 \\
\hline annual changes & & 0.05 & 0.18 & 0.38 & 0.55 & 0.46 & 0.44 & \\
\hline Vegetables/Fruits & 0.02 & 0.07 & 0.12 & 0.17 & 0.22 & 0.27 & 0.32 & 0.85 \\
\hline annual changes & & 0.05 & 0.05 & 0.05 & 0.05 & 0.05 & 0.05 & \\
\hline Coffee and Tea & 1.36 & 2.17 & 3.11 & 4.16 & 5.36 & 6.76 & 8.36 & \\
\hline annual changes & & 0.81 & 0.94 & 1.05 & 1.20 & 1.40 & 1.60 & \\
\hline Coffee & 1.20 & 1.91 & 2.74 & 3.67 & 4.73 & 5.97 & 7.38 & \\
\hline annual changes & & 0.72 & 0.83 & 0.93 & 1.06 & 1.24 & 1.41 & \\
\hline Tea & 0.16 & 0.25 & 0.36 & 0.49 & 0.63 & 0.79 & 0.98 & \\
\hline annual changes & & 0.09 & 0.11 & 0.12 & 0.14 & 0.16 & 0.19 & \\
\hline
\end{tabular}

Source: FSRP, Rwandan authorities and authors' calculations 
Table I.8. Rwanda: Proposed Schedule for Fertilizer Intensification and Associated Production Increases (For Selected Crops. Figures According with FSRP Survey)

\begin{tabular}{|c|c|c|c|c|c|c|c|c|}
\hline & & & & & & & & Agroeconomic \\
\hline Food and export crops & 1.68 & 3.68 & 6.68 & 11.68 & 16.67 & 21.67 & 26.68 & \\
\hline \multirow[t]{2}{*}{ annual changes } & & 2.00 & 3.00 & 5.00 & 5.00 & 5.00 & 5.00 & \\
\hline & & 2.00 & 3.00 & 5.00 & 5.00 & 5.00 & 5.00 & \\
\hline Sorghum & 0.05 & 0.23 & 0.53 & 1.06 & 1.87 & 2.60 & 3.19 & 14.44 \\
\hline annual changes & & 0.18 & 0.30 & 0.53 & 0.81 & 0.73 & 0.59 & \\
\hline Maize & 0.00 & 0.19 & 0.51 & 1.06 & 1.89 & 2.61 & 3.31 & 7.36 \\
\hline annual changes & & 0.19 & 0.32 & 0.55 & 0.83 & 0.72 & 0.70 & \\
\hline Rice & 0.01 & 0.01 & 0.01 & 0.01 & 0.01 & 0.01 & 0.01 & 0.03 \\
\hline annual changes & & 0.00 & 0.00 & 0.00 & 0.00 & 0.00 & 0.00 & \\
\hline Beans & 0.07 & 0.27 & 0.59 & 1.14 & 1.95 & 2.65 & 3.25 & 16.46 \\
\hline annual changes & & 0.20 & 0.32 & 0.55 & 0.81 & 0.70 & 0.60 & \\
\hline Soya & 0.01 & 0.01 & 0.01 & 0.01 & 0.01 & 0.01 & 0.01 & 0.49 \\
\hline annual changes & & 0.00 & 0.00 & 0.00 & 0.00 & 0.00 & 0.00 & \\
\hline Potatoes & 1.49 & 2.41 & 3.74 & 6.02 & 7.07 & 8.37 & 9.87 & 14.56 \\
\hline annual changes & & 0.92 & 1.33 & 2.28 & 1.05 & 1.30 & 1.50 & \\
\hline Sweet potatoes & 0.03 & 0.23 & 0.55 & 1.10 & 1.92 & 2.63 & 3.23 & 21.46 \\
\hline annual changes & & 0.21 & 0.32 & 0.55 & 0.82 & 0.71 & 0.60 & \\
\hline Vegetables/Fruits & 0.03 & 0.08 & 0.13 & 0.18 & 0.23 & 0.28 & 0.32 & 0.32 \\
\hline annual changes & & 0.05 & 0.05 & 0.05 & 0.05 & 0.05 & 0.04 & \\
\hline Coffee and Tea & 1.36 & 2.17 & 3.11 & 4.16 & 5.36 & 6.76 & 8.36 & \\
\hline annual changes & & 0.81 & 0.94 & 1.05 & 1.20 & 1.40 & 1.60 & \\
\hline Coffee & 1.20 & 1.91 & 2.74 & 3.67 & 4.73 & 5.97 & 7.38 & \\
\hline annual changes & & 0.72 & 0.83 & 0.93 & 1.06 & 1.24 & 1.41 & \\
\hline Tea & 0.16 & 0.25 & 0.36 & 0.49 & 0.63 & 0.79 & 0.98 & \\
\hline annual changes & & 0.09 & 0.11 & 0.12 & 0.14 & 0.16 & 0.19 & \\
\hline
\end{tabular}

Source: FSRP, Rwandan authorities and authors' calculations

34. Assuming the GoR (2002a) data set, Table 9 shows that 0.51 percentage points of primary sector GDP growth in 2000 can be ascribed to fertilizer intensification and 1.61 percentage points to other sources. 
Table I.9. Rwanda: Analysis of the PRSP Target Growth Rate for the Primary Sector

(Figures Consistent with National Accounts Figures)

\begin{tabular}{|c|c|c|c|c|c|c|c|}
\hline & 2001 & 2002 & 2003 & 2004 & 2005 & 2006 & Simple Avg \\
\hline & & & $(\operatorname{In~Tl}$ & isand Ton & & & \\
\hline \multirow[t]{2}{*}{ Food Crops } & 114.16 & 132.26 & 177.97 & 146.59 & 155.39 & 165.37 & 148.62 \\
\hline & \multicolumn{7}{|c|}{ Extra production estimated from National Account figures } \\
\hline Selected food crops & 39.78 & 55.82 & 99.42 & 65.87 & 72.43 & 80.11 & 68.91 \\
\hline Sorghum & 0.19 & 1.33 & 2.79 & 4.03 & 3.44 & 3.21 & 2.50 \\
\hline Maize & 0.42 & 1.49 & 3.11 & 4.50 & 3.75 & 4.36 & 2.94 \\
\hline Rice & 1.10 & 0.00 & 0.00 & 0.00 & 0.00 & 0.00 & 0.18 \\
\hline Beans & 0.19 & 0.67 & 1.40 & 2.02 & 1.69 & 1.61 & 1.26 \\
\hline Soya & 0.27 & 0.94 & 1.97 & 2.86 & 2.34 & 0.00 & 1.40 \\
\hline Potatoes & 32.02 & 44.02 & 80.04 & 40.02 & 50.03 & 60.03 & 51.03 \\
\hline Sweet potatoes & 0.71 & 2.49 & 5.23 & 7.56 & 6.31 & 6.02 & 4.72 \\
\hline \multirow[t]{2}{*}{ Vegetables/Fruits } & 4.88 & 4.88 & 4.88 & 4.88 & 4.88 & 4.88 & 4.88 \\
\hline & \multicolumn{7}{|c|}{ Extra production assumed equal to that in the PRSP } \\
\hline Bananas & 64.52 & 66.45 & 68.44 & 70.50 & 72.61 & 74.79 & 69.55 \\
\hline Other roots and tubers & 9.01 & 9.10 & 9.19 & 9.28 & 9.37 & 9.47 & 9.23 \\
\hline Cassava & 8.12 & 8.21 & 8.29 & 8.37 & 8.45 & 8.54 & 8.33 \\
\hline Taro & 0.88 & 0.89 & 0.90 & 0.91 & 0.92 & 0.93 & 0.90 \\
\hline Other & 0.86 & 0.89 & 0.92 & 0.94 & 0.97 & 1.00 & 0.93 \\
\hline Wheat & 0.19 & 0.20 & 0.21 & 0.21 & 0.22 & 0.22 & 0.21 \\
\hline Peas & 0.46 & 0.47 & 0.49 & 0.50 & 0.52 & 0.53 & 0.50 \\
\hline Groundnuts & 0.21 & 0.22 & 0.22 & 0.23 & 0.24 & 0.24 & 0.23 \\
\hline \multicolumn{8}{|l|}{ Export crops } \\
\hline \multicolumn{8}{|l|}{ Coffee } \\
\hline Parchment & 3.60 & 4.14 & 4.76 & 5.48 & 6.30 & 7.24 & 5.25 \\
\hline Green & 2.42 & 2.78 & 3.19 & 3.67 & 4.22 & 4.86 & 3.52 \\
\hline \multicolumn{8}{|l|}{ Tea } \\
\hline Green leaves & 9.44 & 10.85 & 12.48 & 14.35 & 16.50 & 18.98 & 13.77 \\
\hline The Noir & 2.16 & 2.48 & 2.86 & 3.29 & 3.78 & 4.34 & 3.15 \\
\hline
\end{tabular}

Primary sector GDP forecast using PRSP's assumptions regarding fertilizer utilization (in billions of $2000 \mathrm{RF}$ )

\begin{tabular}{|c|c|c|c|c|c|c|c|}
\hline Food crops & 6.20 & 4.56 & 6.43 & 6.12 & 6.72 & 7.34 & 6.23 \\
\hline In percent of 2000 PS GDP & 2.12 & 1.56 & 2.20 & 2.09 & 2.30 & 2.51 & 2.13 \\
\hline Selected food crops & 1.48 & 1.93 & 3.40 & 2.63 & 2.72 & 2.73 & 2.48 \\
\hline In percent of 2000 PS GDP & 0.51 & 0.66 & 1.16 & 0.90 & 0.93 & 0.93 & 0.85 \\
\hline Export crops & 1.07 & 1.22 & 1.41 & 1.62 & 1.86 & 2.14 & 1.55 \\
\hline In percent of 2000 PS GDP & 0.36 & 0.42 & 0.48 & 0.55 & 0.64 & 0.73 & 0.53 \\
\hline Food and export crops & 7.26 & 5.79 & 7.84 & 7.74 & 8.58 & 9.48 & 7.78 \\
\hline In percent of 2000 PS GDP & 2.49 & 1.98 & 2.68 & 2.65 & 2.94 & 3.24 & 2.66 \\
\hline Livestock and other & 1.51 & 1.20 & 1.63 & 1.61 & 1.78 & 1.97 & 1.62 \\
\hline In percent of 2000 PS GDP & 0.52 & 0.41 & 0.56 & 0.55 & 0.61 & 0.67 & 0.55 \\
\hline Total primary sector GDP & 8.77 & 6.99 & 9.47 & 9.34 & 10.37 & 11.45 & 9.40 \\
\hline In percent of 2000 GDP & 1.24 & 0.99 & 1.34 & 1.32 & 1.47 & 1.62 & 1.33 \\
\hline In percent of 2000 PS GDP & 3.00 & 2.39 & 3.24 & 3.20 & 3.55 & 3.92 & 3.22 \\
\hline In percent of PRSP target & 5.30 & 5.30 & 5.30 & 5.30 & 5.30 & 5.30 & 5.30 \\
\hline
\end{tabular}

Source: FSRP, Rwandan authorities authors' calculations 
Table I.10. Rwanda: Analysis of the PRSP Target Growth Rate for the Primary Sector (Figures Consistent with the MINAGRI/FSRP Survey)

\begin{tabular}{|c|c|c|c|c|c|c|c|}
\hline & 2001 & 2002 & 2003 & 2004 & 2005 & 2006 & Simple Avg. \\
\hline & \multicolumn{7}{|c|}{ (In Thousand Tonnes) } \\
\hline \multirow[t]{2}{*}{ Food crops } & 86.70 & 107.63 & 153.30 & 114.84 & 122.48 & 127.49 & 118.74 \\
\hline & \multicolumn{7}{|c|}{ Extra production estimated from National Account figures } \\
\hline Selected food crops & 47.19 & 67.06 & 111.65 & 72.07 & 78.56 & 82.39 & 76.49 \\
\hline Sorghum & 1.28 & 2.13 & 3.75 & 5.72 & 5.15 & 4.16 & 3.70 \\
\hline Maize & 1.30 & 2.15 & 3.74 & 5.64 & 4.89 & 4.76 & 3.75 \\
\hline \multicolumn{8}{|l|}{ Rice } \\
\hline Beans & 0.98 & 1.54 & 2.69 & 3.95 & 3.41 & 2.92 & 2.58 \\
\hline \multicolumn{8}{|l|}{ Soya } \\
\hline Potatoes & 36.08 & 52.16 & 89.42 & 41.18 & 50.99 & 58.83 & 54.78 \\
\hline Sweet potatoes & 2.68 & 4.19 & 7.18 & 10.69 & 9.24 & 7.80 & 6.96 \\
\hline \multirow[t]{2}{*}{ Vegetables/Fruits } & 4.88 & 4.88 & 4.88 & 4.88 & 4.88 & 3.93 & 4.72 \\
\hline & \multicolumn{7}{|c|}{ Extra production assumed equal to that in the PRSP } \\
\hline Bananas & 32.43 & 33.40 & 34.40 & 35.43 & 36.50 & 37.59 & 34.96 \\
\hline Other roots and tubers & 6.46 & 6.52 & 6.59 & 6.65 & 6.72 & 6.79 & 6.62 \\
\hline Cassava & 5.57 & 5.63 & 5.69 & 5.74 & 5.80 & 5.86 & 5.72 \\
\hline Taro & 0.88 & 0.89 & 0.90 & 0.91 & 0.92 & 0.93 & 0.90 \\
\hline Other & 0.62 & 0.64 & 0.66 & 0.68 & 0.70 & 0.72 & 0.67 \\
\hline Wheat & 0.19 & 0.20 & 0.21 & 0.21 & 0.22 & 0.22 & 0.21 \\
\hline Peas & 0.22 & 0.23 & 0.23 & 0.24 & 0.25 & 0.25 & 0.24 \\
\hline Groundnuts & 0.21 & 0.22 & 0.22 & 0.23 & 0.24 & 0.24 & 0.23 \\
\hline \multicolumn{8}{|l|}{ Export crops } \\
\hline \multicolumn{8}{|l|}{ Coffee } \\
\hline Parchment & 3.60 & 4.14 & 4.76 & 5.48 & 6.30 & 7.24 & 5.25 \\
\hline Green & 2.42 & 2.78 & 3.19 & 3.67 & 4.22 & 4.86 & 3.52 \\
\hline \multicolumn{8}{|l|}{ Tea } \\
\hline Green leaves & 9.44 & 10.85 & 12.48 & 14.35 & 16.50 & 18.98 & 13.77 \\
\hline \multirow[t]{2}{*}{ The Noir } & 2.16 & 2.48 & 2.86 & 3.29 & 3.78 & 4.34 & 3.15 \\
\hline & \multicolumn{7}{|c|}{$\begin{array}{l}\text { Primary sector GDP forecast using PRSP's assumptions regarding fertilizer utilization } \\
\text { (In billions of } 2000 \mathrm{RF} \text { ) }\end{array}$} \\
\hline Food crops & 3.54 & 4.23 & 5.71 & 4.81 & 4.99 & 5.08 & 4.73 \\
\hline In percent of 2000 PS GDP & 1.77 & 2.12 & 2.86 & 2.41 & 2.50 & 2.54 & 2.37 \\
\hline Selected food crops & 1.60 & 2.25 & 3.67 & 2.72 & 2.84 & 2.87 & 2.66 \\
\hline In percent of $2000 \mathrm{PS}$ GDP & 0.80 & 1.13 & 1.84 & 1.36 & 1.42 & 1.44 & 1.33 \\
\hline Export crops & 1.07 & 1.22 & 1.41 & 1.62 & 1.86 & 2.14 & 1.55 \\
\hline In percent of $2000 \mathrm{PS}$ GDP & 0.53 & 0.61 & 0.71 & 0.81 & 0.93 & 1.07 & 0.78 \\
\hline Food and export crops & 4.60 & 5.46 & 7.12 & 6.43 & 6.85 & 7.22 & 6.28 \\
\hline In percent of $2000 \mathrm{PS}$ GDP & 2.30 & 2.73 & 3.57 & 3.22 & 3.43 & 3.61 & 3.15 \\
\hline Livestock and other & 0.96 & 1.13 & 1.48 & 1.34 & 1.42 & 1.50 & 1.30 \\
\hline In percent of $2000 \mathrm{PS}$ GDP & 0.48 & 0.57 & 0.74 & 0.67 & 0.71 & 0.75 & 0.65 \\
\hline Total primary sector GDP & 5.56 & 6.59 & 8.60 & 7.77 & 8.28 & 8.72 & 7.59 \\
\hline In percent of $2000 \mathrm{GDP}$ & 0.91 & 1.08 & 1.40 & 1.27 & .135 & 1.42 & 1.24 \\
\hline In percent of 2000 PS GDP & 2.78 & 3.30 & 4.31 & 3.89 & 4.14 & 4.37 & 3.80 \\
\hline In percent PRSP target & 5.30 & 5.30 & 5.30 & 5.30 & 5.30 & 5.30 & 5.30 \\
\hline
\end{tabular}


35. For export crops we replicate the growth rates of Mellor (2002a), which results in a 0.36 percentage points increase of 2000 primary sector GDP, due mainly to fertilizer intensification. Finally, the remaining categories (including livestock) are assumed to grow at a rate which explains 17.2 percent of total primary sector growth and generates a growth equivalent of 0.52 percentage points of the sectoral GDP. ${ }^{32}$

36. Adding up all component growth rates of the primary sector gives us the constant 2000 prices growth rate of 3 percent. This rate should be compared to the target rate of 5.3 percent. Additionally, of the 3 percent increase, only 0.87 percentage points could be ascribed purely to fertilizer intensification Therefore, less than a third of the increase in sectoral GDP growth could be explained by fertilizer intensification. This is below the assumed 75 percent.

37. Assuming the MINAGRI/FSRP (2001) data set, Table 10 shows that 0.8 percentage points of primary sector GDP growth in 2000 can be ascribed to fertilizer intensification and 0.97 percentage points to other sources. Export crops explain a higher percentage of the growth rate compared to the previous data set due to a lower production base (0.53 percentage points of growth for 2001). Finally, other subsectors are assumed to grow at a rate which explains 17.2 percent of total primary sector growth.

38. Adding up all component growth rates of the primary sector gives us the growth rate of 2.8 percent. Of the 2.8 percent increase, 1.3 percentage points can be ascribed purely to fertilizer intensification. This implies that using MINAGRI/FSRP (2001) as a base, approximately half of the increase in the sectoral GDP growth could be explained by fertilizer intensification. Again, this figure is well below the hypothesized 75 percent.

39. The above analysis has focused on the year 2001. Its extension to later periods reveals that the projected primary sector GDP increases are never close to the 5.3 percent target. The estimated (simple) average of primary sector growth for 2001-2006 is 3.2 percent for GoR (2002a) data, and 3.8 percent for MINAGRI/FSRP (2001) data.

40. These results should not surprise if current utilization of land per crop (see Table 5) is considered. Higher ex-ante growth rates of primary sector GDP might be possible if a significant redistribution of land takes place in favor of those crop plantings which are most fertilizer-responsive. Finally, we should emphasize a salient assumption of adequate supply of manure, labor and capital which are forthcoming at all levels of output.

\footnotetext{
${ }^{32}$ Since there are no fertilizer response trials for bananas, other roots and tubers, wheat, peas, groundnuts and export crops, production increases of these crops followed those of Mellor (2002a) If anything, the estimates are upward biased.
} 


\section{Upshots for the overall growth strategy}

41. The primary sector has been assumed throughout to be the engine of growth strategy. The key rationale is the large share of this sector in GDP and the large proportion of agricultural employment in total employment.

42. However, the following factors introduce uncertainty into our model:

- $\quad$ Assumptions about primary sector shares in GDP;

- internal consistency of sector target growth rates based on available information;

- $\quad$ sustainability of primary sector growth rates given resource endowments and fertilizer response;

- $\quad$ assumptions about crop gains for which there are no known fertilizer response trials;

- $\quad$ assumptions about fertilizer effectiveness and proportions of its application

- $\quad$ assumptions about land conservation investments and labor/capital supply elasticities;

- $\quad$ assumptions about size of rural non-farm output potential, rural unemployment, elasticity of non-farm growth with respect to farm growth, and shares of formal and informal sectors in GDP.

43. If for any of these reasons the primary sector expands at a lower rate the overall GDP and employment will lag accordingly. The difference between the GoR and MINAGRI/FSRP statistics alone accounts for 10 percentage points gap in the size of the primary sector. More research on fertilizer response should be conducted for different combinations of crops/ABC zones, as well as on conditions in which inorganic fertilizer is used. Inadequate combinations of organic and inorganic fertilizer could render disappointing results as emphasized in Kelly and Murekezi (2000) and Kelly et al (2001b). Finally, it is important to consider a market for fertilizer which could be a constraining factor. This is specially relevant given the uncertainty associated with land tenure and land tenure institutions.

\section{The Market for Fertilizer}

44. At this point, it is clear that fertilizer intensification is the main factor behind high targeted growth rates of agriculture. We will therefore examine the current trends in Rwanda's market for fertilizer. Kelly and Murekezi (2000), Kelly et al (2001a) and Kelly et al (2001b) analyzed this market as part of Rwanda's FSRP while Abt Associates (2002) and 
Desai (2002) did the same within the APDP). This section summarizes their findings, with special emphasis on those elements which could hamper effective fertilizer demand. ${ }^{33}$

\section{The supply of fertilizer}

45. The (chemical) fertilizer used in Rwanda is imported from external sources: no domestic production base exist. Fertilizer is imported by a few private traders, mainly through Dar-es-Salaam, which replaced Mombassa as the main port of entry. Some NGOs have also added to the supply in recent years. In 1995-98 the EU supported exports of fertilizer to Rwanda under a sliding scale of subsidy which decreased from 50 percent in 1995 to 20 percent in 1998. From 1999 on the market for fertilizer has become fully liberalized. A Ministry of Agriculture decree, which banned distribution of free or subsidized farm inputs, was followed by two laws $(05 / 2000$ and $06 / 2000)$ which regulate imports of agricultural products, and which exempted fertilizer from duties and sales taxes for a period of three years. ${ }^{34}$ These measures support the development of the private sector free from institutional distortions. It appears that the supply response has been good (see Cook in Abt Associates (2002) and Desai in Abt Associates (2002) and Desai (2002)).

46. Mauritius is Rwanda's largest fertilizer trading partner. This points to unfulfilled potential economies of scale in transportation which could lower prices in the future. The actual supply could be higher than total imports as reported by the National Bank of Rwanda (NBR). The unclassified imports through the Cyanika border post (Cook in Abt Associates, 2000) might explain the difference.

47. There seem to be two main regional markets. The one in the Northwest has a center in Ruhengeri, while the rest of the country is supplied from Kigali-Ville. Informal traders are more common in Ruhengeri and formal traders more common in Kigali-Ville (Cook, in Abt Associates, 2002). Some supply inadequacies prevail (Desai, 2002), Kelly et al (2001a)).

48. Distribution to farmers takes place through cooperatives and wholesale traders who buy fertilizer from importers and sell it on by the sack ( $50 \mathrm{kgs}$. per sack). Retailers and producers' associations sell by the sack or less-than-sack. Wholesalers may grant credit to retailers or buyer by-the-sack, with allocation on a case-by-case basis. In turn, Cooperatives may sell fertilizer to non-members if the latter pay in cash (Cook in Abt Associates, 2000). Sixty percent of fertilizer operations are cash-based (Kelly et al, 2001a).

49. The Agriculture and Rural Market Development Project (ARMDP), managed by the World Bank, attempted to promote a virtuous circle of fertilizer utilization through extension of credit. However, he project met limited success (Desai, 2002).

\footnotetext{
${ }^{33}$ See Appendix 2 for a more detailed description of fertilizer utilization during 2000.

${ }^{34}$ These exemptions may be extended for additional three years by a presidential decree.
} 


\section{The demand for fertilizer}

50. The main users of inorganic fertilizer are OCIR-Thé and OCIR-Café (Desai in Abt Associates (2002) and Cook in Abt Associates (2002)). Outside of coffee and tea, fertilizer in mostly applied in the Ruhengeri and Gisenyi provinces and for growing Irish potatoes.

51. Individual private demand is feeble and quantities demanded relatively small. According to FSRP figures for 2001, from a sample of 1500 households only 72 bought fertilizer. They purchased altogether 1.59 tones, with a mean of $22 \mathrm{kgs}$, a median of $10 \mathrm{kgs}$, and a mode of $1 \mathrm{~kg}$ per household (Cook in Abt Associates, 2002). According to Kelly et al (2001b) there exist crop/ABC combinations that could be profitably exploited through fertilizer intensification.

52. A growing number of farmers' associations seem to benefit from preferential treatment accorded by NGO (Murekezi in Abt Associates, 2002). Farmers' associations join larger cooperatives, which in turn, grant them credit. Some cooperatives, however, are unwilling to take on new members because of debt collection problems (Cook in Abt Associates, 2002).

\section{Some corollaries}

53. Higher import volumes could bring about substantial decreases in the cost of fertilizer, benefiting from economies of scale in transportation. Prices are relatively high due to low import volumes and inefficiencies in the supply chain (Desai in Abt Associates, 2002) and Desai (2002).

54. Low fertilizer demand, which impedes exploitation of profitable opportunities, stems from farmers' knowledge gaps, cash constraints, and an unregulated land tenure system. Kelly et al (2001a) points at some contradictions of farmers' knowledge about complementarity of organic and inorganic fertilizer, fertilizer and pesticides application, and the importance of seed quality. It seems that many opportunities are, indeed, already known to farmers. Cash constraints do appear to depress effective demand as agricultural production in Rwanda is mostly of the subsistence type. Many farmers cite high prices as a reason for not using fertilizer (Kelly et al, 2001a). The decreasing average farm size combined with rapid population growth hamper the design of programs addressing this constraint. However, the smaller the average farm, the larger the gains made possible through farmers' associations. A program like the World Bank's ARMDP contains many elements needed to solve the cash dilemma. Rwanda's fertilizer market seems to suffer not from lack of suppliers' working capital but from lack of effective demand. ${ }^{35}$ For this strategy to succeed,

\footnotetext{
${ }^{35}$ At 2000 prices and exchange rates the market was estimated at 5,000 tones of inorganic fertilizer or barely more than US\$3 million. The ARMDP program boasted resources of US\$5 million financed by a concessional IDA loan.
} 
loan collection rates should increase.$^{36}$ Fertilizer utilization may not be directed towards the most responsive crops due to poor education. The ubudehe mu kurwanya ubukene decentralization mechanism, as described in the PRSP, could be deployed to correct for this shortcoming. ${ }^{37}$

55. Low levels of fertilizer demand could also stem from land tenure deficiencies. As Khan (2000) emphasizes, property rights are neither well-defined nor well enforced. ${ }^{38}$

\section{Conclusions}

56. The analysis of the agricultural strategy for Rwanda has shown that sustainable economic growth is achievable under the right policy mix. However, poverty reduction consistent with the Vision 2020 targets will be difficult to attain even under the most favorable fertilizer intensification. Notwithstanding the appropriateness of the theoretical approach undertaken here, we feel that the development of the primary sector should remain a cornerstone of any strategy. Agriculture makes up the largest part of GDP and so has the greatest potential to reduce poverty

57. Although the original PRSP considered various sectoral strategies, including one for agriculture, the recent Progress Report recognizes difficulties in drafting a coherent approach. The authorities explain away the delays through lack of resources, although inadequate prioritization plays a role, too. Our findings may serve as guideposts to devise a lucid strategy for the agricultural sector.

58. First, there is an urgent need to improve the methodology of estimating the GDP in general, and the primary sector in particular. The extension of FSRP surveys within the framework of national accounts is a step in the right direction.

59. Second, it would be advisable to conduct fertilizer response trials for those crops and $\mathrm{ABC}$ zone combinations which are currently not included in the Ministry of Agriculture/FSRP database. With the current composition of crops fertilizer responses, potential GDP growth rates of around 5 percent are sustainable only for four years at most. Fertilizer utilization surveys should be conducted regularly to estimate marginal physical

\footnotetext{
${ }^{36}$ Kelly et al (2001b) actually discourage use of credit-based schemes. Kelly believes that free distribution of fertilizer could trigger a virtuous circle of productivity and income growth. She cites failed experience with credit-based schemes in other African countries where repayment rates were very low (Kelly, personal communication).

${ }^{37}$ See Appendix A of the PRSP.

${ }^{38}$ As of this writing, the government of Rwanda is preparing a land tenure reform law which would grant deeds of ownership to all farmers tilling or occupying land. The deeds would be fully transferable and an open market for them upheld and encouraged. If implemented and enforced, this change could contribute to concentration of holdings and growth in income, which in turn, could alleviate the cash shortages mentioned above.
} 
products for different crops and $\mathrm{ABC}$ combinations. This would help identify areas in which lack of organic fertilizer application or soil conservation act as constraints for growth.

60. Third, target growth rates for the primary sector can be achieved only if stronger fertilization than that assumed in the PRSP is in place. More attention should be paid to improvements of other inputs, such as seeds, labor or soil (through conservation investments).

61. Fourth, while the approach taken in this study was static, the problems which Rwanda face are dynamic in nature. In the medium term, most economic variables are endogenous. For example, increases relative supply of some products will affect V/C ratios. An adequate growth strategy should take into account changes in behavior and incentives.

62. Fifth, the development of a well-functioning market for fertilizer is key to achieving the growth objectives specified in the PRSP. Of paramount importance are policies to stimulate effective fertilizer demand. Among barriers we have identified are lack of knowledge, cash constraints, marketing problems and inadequate land-tenure laws. Of those, the former three seem to be the most important.

\section{Two additional points should be made here:}

63. Various support programs (public and private) ought to be integrated under one sectoral strategy. This will economize resources, avoid duplication and provide for a coherent effort to fight poverty.

64. Finally, key priority expenditure programs would benefit from an estimation of expected rates of return. This would improve the monitoring process by establishing benchmarks against which results could be compared. 


\section{References}

Abt Associates, 2002, Fertilizer Use and Marketing Policy Workshop Proceedings, Agricultural Policy Development Project, Research Report No. 10, July, Abt Associates Inc.

Ames, B., W. Brown, S. Devarajan and A. Izquierdo, 2001, "Macroeconomic Policy and Poverty Reduction."

Clay, D. and V. Kelly, E. Mypisi, T. Reardon, Input Use and Conservation Investments among Farm Households in Rwanda: Patterns and Determinants, FSRP.

Crissman, C., 2002, A Proposal for a Rwanda Potato Sector Development Program, Agricultural Policy Development Project, Research Report No. 17, August 2002, Abt Associates Inc.

DeRosa, D. and V. Roningen, 2002, Rwanda as a Free Trade Zone: An Inquiry into the Economic Impacts, Agricultural Policy Development Project, Research Report No. 11, July 2002, Abt Associates Inc.

Desai, G., 2002, Key Issues in Achieving Sustainable Rapid Growth of Fertilizer Use in Rwanda, Agricultural Policy Development Project, Research Report No. 16, August 2002, Abt Associates Inc.

Farmer, R, 1993, The macroeconomics of self-fulfilling prophecies, MIT Press.

Goosens, F., 2002, Potato Marketing in Rwanda, Agricultural Policy Development Project, Research Report No. 12, January 2002, Abt Associates Inc.

Government of Rwanda (GoR), 2000, National Accounts of Rwanda, A Technical Handbook, December.

Government of Rwanda, (GoR), 2001a, Rwanda Development Indicators 2000.

Government of Rwanda, (GoR), 2001b, Poverty Reduction Strategy Paper. Drafts from September, November and December.

Government of Rwanda, (GoR), 2002a, Rwanda Development Indicators 2001.

Government of Rwanda, (GoR), 2002b, Poverty Reduction Strategy Paper (Draft), March.

Government of Rwanda, (GoR), 2002c, Poverty Reduction Strategy Paper, July.

Government of Rwanda, (GoR), 2003, PRSP Progress Report, July.

IMF, 2001, Aide Memoire of the IMF Mission to Kigali, November 5-19. 
IMF, 2002a, Staff Report for the 2002 Article IV consultation

IMF, 2002b, Rwanda: Statistical Appendix.

IMF, World Bank (IMF/WB), 2002, Joint Staff Assessment for Rwanda PRSP.

Kairaba, A., 2002, "Rwanda Country Case Study"

Kelly, V. and A. Murekezi, 2000, Fertilizer Response and Profitability in Rwanda, FSRP, February 2000.

Kelly, V. and E. Mypisi, E. Shingiro, J. Nyarwaya, 2001a, Agricultural Intensification in Rwanda: An elusive Goal. Fertilizer Use and Conservation Investments, FSRP, January 2001.

Kelly, V. and E. Mypisi, A. Murekezi, 2001b, D. Neven, Fertilizer Consumption in Rwanda, Past Trends, Future Potential and Determinants, FSRP, February 2001.

Khan, M., 2000, Rural Poverty in Developing Countries: Issues and Policies, IMF Working Paper, WP/00/78.

Loveridge S., 2002, Decaffeinated? Situation, Trends and Prospects for Coffee Production in Rwanda, Analysis of a Rural Household Survey, 2002, FSRP, August 2002.

Mackinnon, J. and A. Thomson, Ida Hakizinka, L. Rugwabiza, The impact of increases in public expenditure on Poverty in Rwanda, Oxford Policy Management for DfID, January 2003.

Mellor, J. and C. Ranade, 2002a, The Impact of Agricultural Growth on Employment in Rwanda: A Three Sector Model, Agricultural Policy Development Project No. 14, August, Abt Associates Inc.

Mellor, J. and C. Ranade, 2002b, Why does Agricultural Growth in Low and Middle Income Countries Reduce Poverty so much more than Urban Tradable Growth?- The Critical Intermediary Role of Non-Tradables, Mimeo, September.

Mellor, J., 2002a, How Much Employment Can rapid Agricultural Growth Generate? Sectoral Policies for Maximum Impact in Rwanda, Agricultural Policy Development Project, Research Paper No. 13, August, Abt Associates Inc.

Mellor, J., 2002b, Productivity Increasing Rural Public Works- An Interim Approach to Poverty Reduction in Rwanda, Agricultural Policy Development Project, Research Paper No. 15, August, Abt Associates Inc.

MINAGRI (DSA), FSRP, 2001, Statistiques Agricoles: Production Agricole, Elevage, Superficies et Utilisation des terres, Année Agricole 2000. 
MINAGRI (DSA), FSRP, 2002, Statistiques Agricoles: Production Agricole, Elevage, Superficies et Utilisation des terres, Année Agricole 2001.

MINAGRI (DSA), FSRP, 2003, Statistiques Agricoles: Production Agricole, Elevage, Superficies et Utilisation des terres, Année Agricole 2002.

Musahara, H. 2001, “Land and Poverty in Rwanda”, Landnet Rwanda Chapter.

USAID, 1996, "Promoting Food Security in Rwanda through Sustainable Agricultural Productivity", Project Number 698-0478.

World Bank, 2002, "Building a Sustainable Future: The Africa Region Environment Strategy" 


\section{RWANdA's COFFEe EXPORTS: PAST EXPERIENCE AND LESSONS FOR THE Future ${ }^{39}$}

\section{A. Introduction}

65. The Rwandese authorities adopted an ambitious growth strategy for the country's coffee sector, which accounted for nearly a quarter of total merchandize exports in 2003. Given its importance for export performance, the Rwandese authorities targeted improving the performance of the coffee sector, along with tea and tourism, as a critical element in their export promotion strategy (EPS). Under the EPS, coffee exports are programmed to more than double under a seven year plan that was initially expected to begin in 2003. In a move to improve the quality of coffee exports, the strategy targets an increase in the share of higher quality, fully-washed coffee from 3 percent of total coffee exports (in volume terms) in 2003 to 60 percent by 2010. Overall, annual export earnings would increase to a range of US\$52 million to US\$62 million by 2010, from US\$15 million in 2003 (see OCIR-Café, Action Plan 2003-2010, September 2003).

66. The strategy's implementation represents a considerable challenge, given that the coffee sector's performance has been continuously declining over the past twenty years. Exports, which account for almost all of domestic production, have experienced substantial fluctuations, peaking at 46,000 tons in 1986 and declining to a low of 14,700 tons in 2003 (Figure II-1). Within this variation, the genocide in

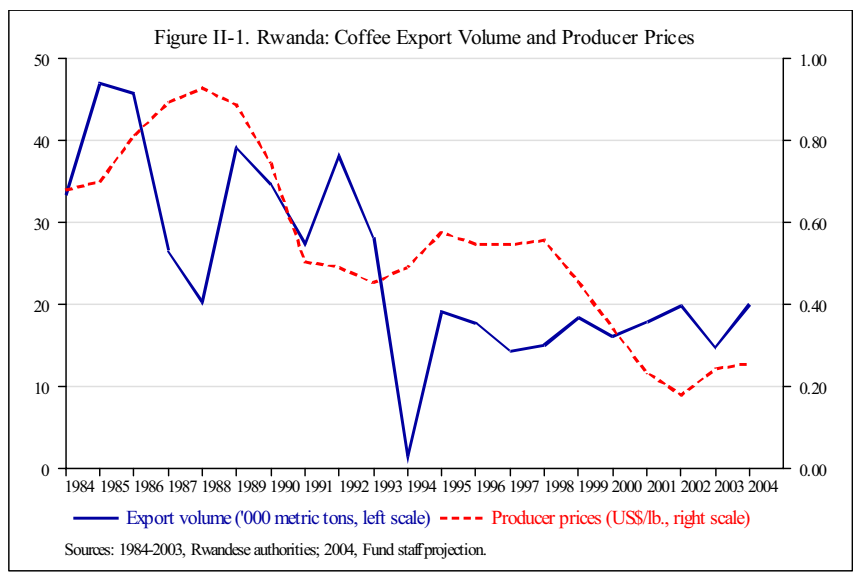
1994 marks a clear turning point, after which volumes experienced a sharp and persistent drop relative to their pre-war levels: in 2003, nine years after the event, coffee exports were still at about only 50 percent of the 1993 level.

\section{A combination of several domestic factors impeded export volumes to recover} more fully in the post-genocide era:

- $\quad$ Efforts to replace aging coffee trees had been significantly scaled down and led to lower productivity and poorer bean quality; ${ }^{40}$

\footnotetext{
${ }^{39}$ Prepared by B. Rother (PDR).

${ }^{40}$ Significant efforts to renew the stock of trees only started recently: OCIR-Café targets the replacement of 40 million out of an estimated total of 60 million trees throughout the next years. However, in 2004, the first year of the program, only some estimated 4 million have been replaced. For 2005, OCIR-Café intends to rejuvenile another 6 million.
} 
- $\quad$ the change in the responsibilities of OCIR-Café, the government's sectoral support body, toward a role focused on promotional activities and quality assurance effectively eliminated an important channel of providing extension services to many small farmers and associations;

- the use of input factors decreased sharply, in part as a result of changes at OCIRCafé. Fertilizer consumption in 2002 was estimated at 128 tons compared to the 5,200 tons that had been targeted under the EPS (see Coffee action plan, p.2);

- $\quad$ the sector's fragmented production structure, which is dominated by individual farmers and farmer associations, suffers from poor access to capital and unsettled disputes over land titles;

and finally, many small scale producers lack the necessary skill set.

68. Beyond this, export performance suffered from an almost continuous decline in unit prices, with Rwandese producer prices falling from levels around US $\$ 0.90$ per pound. in the late 1980 s to US $\$ 0.26$ in 2002 . While prices rose modestly over the past year, partially driven by a bad harvest in Brazil, the outlook for the medium-term is uncertain.

69. The remainder of the paper contains a comparative analysis of Rwanda's recent experience relative to other Arabica producing countries, with the aim of assessing the authorities' EPS in a broader perspective. In Section B, we examine whether price and volume trends observed in Rwanda's coffee export sector between 1997 and 2003 had been shared by its main competitors or were, alternatively, country-specific phenomena. The section also contains a cross-country analysis which seeks to identify key drivers of export volume growth - with the objective of better understanding whether Rwanda is exposed to some severe structural disadvantages vis-à-vis other producer countries. In Section C, the discussion then relates the empirical results to Rwanda's coffee strategy, focusing on whether the findings are broadly consistent with the main thrust of the document.

\section{B. Comparative Performance of Rwanda's Coffee Sector}

70. Is Rwanda's experience of declining export volumes and producer prices unique or is it a trend widely shared among Arabica exporting countries? The exercise to put Rwanda's performance in perspective is guided by the following set of questions:

- How did producer prices evolve for Rwanda relative to its competitors, both in terms of level and volatility?

- $\quad$ How did Rwandese export volumes change compared to those of other Arabica producing countries over the last six years?

- $\quad$ And finally, do specific structural conditions help explaining cross-country variability in export performance? As data limitations only allow a quantitative study of the main Arabica market rather than smaller niche segments, the focus in this part 
of the study lies on the explanation of export volume growth, with producer prices being assumed to be largely beyond the control of the individual exporting country.

The data set covers 21 Arabica producing countries over the period 1997-2003 and was constructed from published data of the International Coffee Organization (ICO). ${ }^{41}$ It is accessible under www.ico.org and was completed, for macroeconomic concepts, by data drawn from the IMF's World Economic Outlook database.

\section{Price Developments, 1997-2003}

\section{The decline in producer prices had been a global phenomenon, but African countries were particularly exposed to negative world market trends:}

- While a substantial gap can be observed between wholesale (proxied by the ICO indicator, which is a weighed average of New York and German market prices) and average producer prices, the mark-up was not stable over time: for the average producer country, the price gap narrowed in 2000-01 and remained roughly unchanged thereafter (Figure II-2a). In Rwanda, however, producer prices continued to fall in 2002-03, and producers faced a discount of about US $\$ 0.20$ per pound. relative to the average competitor.

\footnotetext{
${ }^{41}$ The country sample includes Bolivia, Burundi, Costa Rica, Dominican Republic, El Salvador, Ethiopia, Guatemala, Haiti, Honduras, Jamaica, Kenya, Malawi, Mexico, Nicaragua, Panama, Paraguay, Peru, Rwanda, Venezuela, Zambia, and Zimbabwe. Robusta producers and countries producing both Arabica and Robusta species are left unconsidered. Cuba is excluded due to lack of data, as are Brazil and Columbia based on the fact that these countries produce particular species of the Arabica coffee. For Zimbabwe, 1997 producer prices were excluded from the data set, as the statistics report an improbable 613 percent increase, which risks distorting the overall picture. However, a 640 percent growth rate for Venezuelan coffee exports in 2002 has been kept in the sample, given the substantial degree of variation in export volumes for this country over the entire sample period. The qualitative regression results do not change when excluding this observation.
}

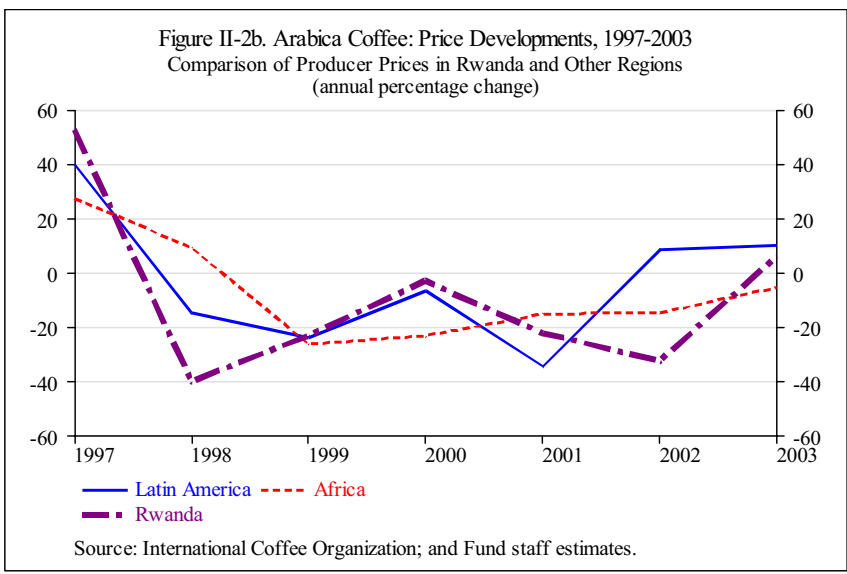


- Lower-than-average and declining producer prices are not unique to Rwanda, but are largely shared by other African countries (Figure II-2b). In contrast, prices in Latin America increased in 2002-03, which-given stagnant wholesale prices - in their cases led to a substantial reduction in the wholesale margin.

72. While the price volatility experienced by African countries has not, in general, been greater than that faced by their Latin American peers, the price fluctuations faced by Rwandan producers were relatively high (Table II-1). To the extent that a high degree of price volatility makes longer-term price trends more difficult to observe, it could be detrimental to producers' decision making. On the other hand, if domestic stabilization schemes to smooth producer prices were not closely linked to world market conditions, they risk Table II-1. Variation of Price Changes Around Mean, 1997-2003 (Standard deviation)

\begin{tabular}{|l|c|}
\hline El Salvador & 0.40 \\
\hline Ethiopia & 0.26 \\
\hline Guatemala & 0.17 \\
\hline Honduras & 0.35 \\
\hline Kenya & 0.35 \\
\hline Malawi & 0.12 \\
\hline Peru & 0.23 \\
\hline Rwanda & 0.29 \\
\hline Wholesale prices & 0.27 \\
\hline
\end{tabular}

representing a significant burden on public finances and might distort production decisions. ${ }^{42}$

\section{Export Volumes, 1997-2003}

\section{In terms of export volumes,} Rwanda underperformed relative to its competitors, particularly given the expectation of temporarily overshooting growth rates as a reaction to the genocide-induced break-down of exports in 1994:

\section{- $\quad$ Rwanda's production} performance varied substantially from that of other producers. In five out of the seven years, Rwanda's coffee exports underperformed average cross-

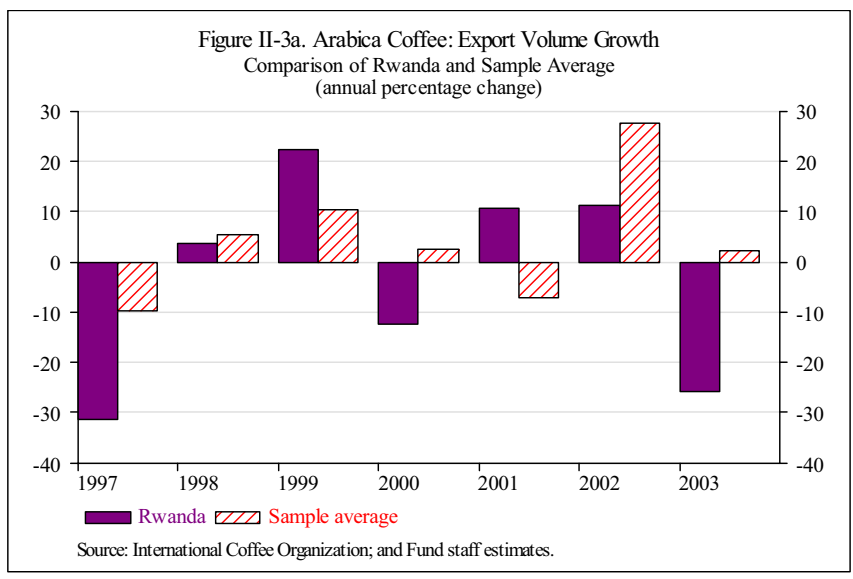
country growth rates. 1997 and 2003 were two particularly bad years for the country, with export volumes dropping by 31 percent and 23 percent respectively

\footnotetext{
${ }^{42}$ (Temporarily) higher price volatility, as in the case of Kenya, could be the consequence of a regime shift from a marketing system based on a stabilization scheme to an auction-based one, which might involve a substantial degree of learning from market participants.
} 
(Figure II-3a). On the other hand, 2001 was an unusually strong year for Rwandese coffee exports, when most competitors recorded a decline in volumes.

- Interestingly, the other African producers including Burundi, which is geographically close to Rwanda and should therefore be exposed to similar climatic conditions, did not share the poor growth in 1997 and 2003 (Figure II-3b).

- One issue which is not unique to Rwanda but shared among all producers is a relatively high degree of volatility in export

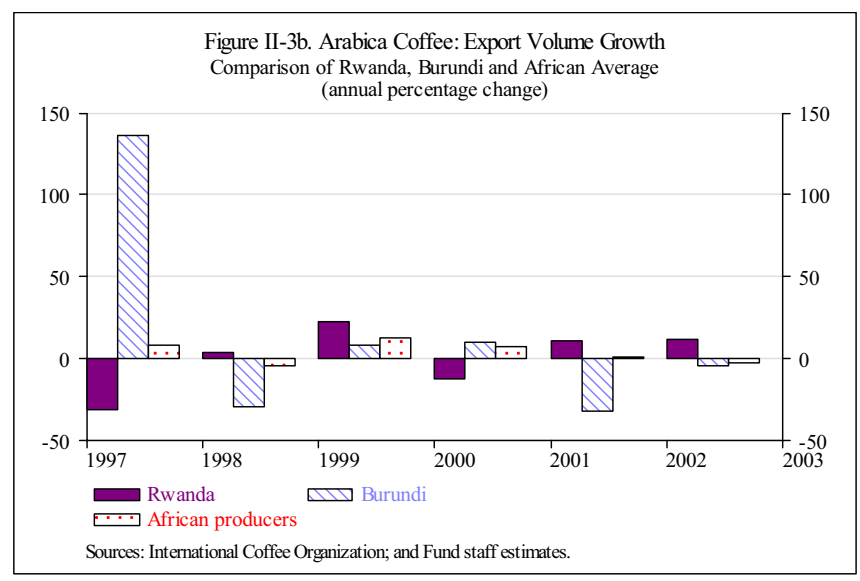
growth.

\section{E. Explaining Export Volume Growth: A Cross-country Panel}

\section{As small countries are typically price takers in commodity markets like coffee,} efforts to strengthen export performance generally focus on volume growth. This section will therefore examine statistical relationships between a (necessarily incomplete) list of plausible explanatory factors and coffee export volumes. In particular, the exercise focuses on whether there are any structural conditions bearing on Rwanda that constitute a systematical obstacle for the sector's future performance - and which therefore would need to be explicitly addressed by appropriate action in the context of the authorities' EPS. The variables included in the analysis (variable names in brackets) and the hypotheses on their expected relationship to volume growth are as follows:

- $\quad$ The lagged change in producer prices relative to wholesale prices (lagged price change). ${ }^{43}$ Given the delay of roughly one year between the production decision and the actual sale of the coffee harvest ${ }^{44}$, strong price increases in year $\mathrm{t}-1$ should stimulate year $\mathrm{t}$ production levels. While this reaction function is backward-looking and not fully consistent with the axiom of rational behavior, it might still be a plausible assumption as it takes account of the fact that reliable information on future price trends is generally unavailable to small farmers. The observed high degree of

\footnotetext{
${ }^{43}$ The variable measures the change in producer prices relative to the change of wholesale prices as proxied by the ICO Indicator prices for other mild Arabicas, which is a weighed average of the New York and German markets. Reported regression results do not change substantively when using simple producer price changes instead.
}

${ }^{44}$ Almost the entire Rwandese coffee production is sold on the Kigali spot market. 
cyclicality in coffee prices further supports such a view, with high prices in one period driving higher production levels for the next year, which, in turn, create an excess supply on the market and consequently drive down prices again.

- $\quad$ The country's share in the global Arabica market (size 1). ${ }^{45}$ The higher the share in total world production, the more selling power should the country's exporters enjoy, supported by a high degree of brand recognition and well-established marketing/ distribution networks. In such circumstances, production increases should be easy to sell.

- $\quad$ The share of coffee exports in total merchandise exports (size 2). Whereas size 1 could be interpreted as a pull-variable, driven by international demand for a country's Arabica exports, size 2 is a push-variable: the higher the importance of the coffee sector for earning foreign exchange, the more a country might be forced to rely on its continued performance to cover the Balance-of-Payment's financing gap. One should thus expect a high level of commitment to increase export volumes in situations where foreign exchange remains scarce. On the other hand, good prices should be harder to achieve given the pressure to sell.

- $\quad$ Domestic GDP growth (GDP growth). Stronger domestic growth performance could lead to lower coffee export volumes. First, a reallocation of production factors out of the (typically) traditional coffee sector toward higher value-added activities, especially in countries facing severe capital constraints, could lead to a drain on resources. In addition, higher domestic growth might lead to higher domestic coffee consumption at the expense of exports.

- Industrialized countries' GDP growth (GDP/OECD). The higher world demand for coffee, which is proxied by real GDP growth in industrialized economies, the higher should be export volume growth.

- Transportation costs (landlocked). Landlocked countries should face higher transportation costs compared to countries with port access, and should therefore be at a disadvantage to market their coffee production. ${ }^{46}$

- $\quad$ Production technology (per capita income). More advanced technology, including public infrastructure, should help to boost coffee production. Lacking a better variable to pick-up this effect, per capita income is used as an approximation.

\footnotetext{
${ }^{45} 2003$ export data is used to determine both size variables. Note that these do not change over time.

${ }^{46}$ As there is no railway system in Rwanda, coffee exports by truck travel between 5 and 20 days to reach Mombassa.
} 
- Geographical region (Latin). Systematical differences between Latin American and African Arabica producers including with regard to climatic conditions, the protection of property rights, or ownership structures, could translate into divergences in outcomes.

\section{The data suggest that export volume growth is strongly correlated with producer price changes, the share of coffee in total merchandise exports, and GDP growth. In} all these cases, the sign of the correlation coefficient points into the expected direction (Table II-2): price increases, a high dependence of the country on the coffee sector for foreign exchange earnings, and high industrialized countries' GDP growth are positively associated with export volumes, whereas higher domestic GDP growth seems to be paralleled by a decline in coffee exports. On the other hand, size 1, transportation costs, production technology, as well as geographical region do not seem to be linked, to a meaningful extent, to export growth performance. $^{47}$

\section{These findings are} broadly confirmed by a simple OLS regression of export volume on its various explanators. A simple model without time and country dummies shows again that lagged price changes, size 2 , and GDP/OECD are all positively correlated with export volume growth (Table

Table II-2. Correlation Coefficients with volume change

\begin{tabular}{|l|c|}
\hline Lagged price change & 0.21 \\
\hline Size 1 & 0.04 \\
\hline Size 2 & 0.18 \\
\hline Latin & -0.07 \\
\hline Landlocked & 0.07 \\
\hline GDP growth & -0.21 \\
\hline GDP/OECD & 0.12 \\
\hline Per capita income & -0.07 \\
\hline
\end{tabular}

II-3). In addition, all these relationships are significant at least at the 10 percent level. And as above, domestic GDP growth is shown to have a negative effect on export performance, a result which is significant even at the one percent level. However, the various coefficients' strength and therefore their relative effect on exports varies greatly: industrialized country GDP growth has the strongest impact, followed by domestic GDP growth, size 2, and lagged price changes. The coefficient for size 1 also shows a strong impact with the expected sign,

\footnotetext{
${ }^{47}$ The correlation coefficients reported use only the subset of data with no missing values on any of the variables listed. A pairwise regression, which uses all of the observations available for each variable pair, indicates that only the correlations of volume change with lagged price change and domestic GDP growth are significant at least at the five percent level.
} 
but it remains statistically insignificant. ${ }^{48}$

\section{Interestingly, African Arabica exporters do not seem to suffer from} systematically lower volume growth rates than their Latin American competitors. However, the inability to establish a statistically significant difference in performance between the two regions in the regressions might partially be attributed to the fact that the size variables absorb some of the inter-regional variation:

- $\quad$ On average, African producers only represented 2.7 percent of the total Arabica market (size 1), whereas coffee exports totaled 23 percent of their merchandise exports (size 2). ${ }^{49}$

- $\quad$ The average world market share of Latin American countries is more than twice as high as that of their African peers, but coffee exports represented only 3.6 percent of their total exports.

\section{F. Implications for Rwanda's Coffee Sector}

\section{The authorities' strategy to move to niche segments of the Arabica market could} help raising Rwandan coffee export prices. As the cross-country comparison revealed, Rwandese coffee producers faced a large discount relative to Arabica wholesale prices, which even grew in recent years. Partially, this gap might have been caused by lower or uneven quality related to the aging of the tree stock. But it might also reflect insufficient selling power on the international market due to the low share of Rwandese exports in the total Arabica market (about one percent of the sample countries' total Arabica exports). A shift of production toward niche markets could help overcoming this structural disadvantage: supported by the strategy's efforts to enhance bean quality, the differentiation of Rwandese coffee aiming at the creation of privileged marketing and distribution channels for the country's exports could increase its selling power over time and make Rwandese coffee a strong brand in exclusive segments.

\footnotetext{
${ }^{48}$ The results remain broadly robust when controlling for country and time effects. But while many country dummies had been significant, pointing to substantial country-specific information, year dummies were never found to be relevant. More specifically, in a model with country dummies only, the size 2 variable drops out of the estimation. In a specification with time dummies only, the GDP OECD variable falls out of the estimation, but none of the year dummies becomes significant. In a specification with both country and time dummies, the size 2 and the GDP OECD variables drop out of the equation; and eight country dummies are found to be significant at the 10 percent level.

${ }^{49}$ T-tests on the equality of means among Latin American and African Arabica producers reject the null hypothesis of equal means at the 10 percent level for both of the size variables, but not for average volume and price changes.
} 
78. However, a shift merely toward fully-washed coffee might not be enough to create a significant competitive advantage for Rwanda. Many countries are currently adjusting to the higher demand for fully-washed coffee, so that this particular product risks becoming a new market standard rather than a niche. In such a scenario, the high growth rates and price margins programmed in the current EPS might not be achievable. ${ }^{50}$ Therefore, and looking forward, a further development of the authorities' strategy might be warranted, aiming at an intensified diversification of coffee production into segments such as certified organic, gourmet (selected big beans), or mountain coffee.

\section{The regression results suggest that Rwanda's status as a poor and landlocked} African country should not necessarily impede on coffee export growth. The fact that none of these structural conditions was found to be significantly related to export growth warrants some cautious optimism for Rwanda's coffee strategy. This assessment is further supported by the strategic importance of the sector ${ }^{51}$ for the country's foreign exchange earnings and debt sustainability, as well as the resulting strong commitment on the parts of the authorities to swiftly take action (the positive influence of the size 2 variables). However, the analysis also suggests that the coffee sector would continuously be exposed to a high degree of volatility, as export volumes strongly respond to changes in (lagged) producer prices relative to wholesale prices as well as demand conditions in OECD markets - two factors that are largely beyond the control of the producer countries.

\section{Finally, the growth of export volumes might gradually decline in line with the} development of the Rwandese economy. Such a trend should primarily be driven by a reallocation of scarce production factors including capital, which would be expected to gradually shift out of coffee production toward other sectors of the economy. To the extent that such a shift in the production structure strengthens Rwanda's export base and leads to increased diversification, it should be welcomed by policymakers.

\footnotetext{
${ }^{50}$ The current coffee strategy document assumes long-term unit prices for fully-washed coffee of US $\$ 1.74$ per kilogram in a low scenario and of US\$2.20 in a high scenario. This projection appears very optimistic when compared to the current level of US\$1.10 for ordinary coffee. As a point of comparison, fully-washed coffee from Burundi sold for US\$1.20 per kilogram in July 2004.
}

${ }^{51}$ It is only in Burundi and Ethiopia that coffee exports represent a higher share of total merchandise exports. 


\section{Modeling Rwanda’s Money Multipliers And Money Demand ${ }^{52}$}

\section{A. Introduction and Summary}

81. This paper investigates the potential usefulness of econometric analysis of the money multipliers and money demand for informing monetary policy in Rwanda. We examine the reliability of the results generated by simplified versions of econometric models for the behavior of the money multipliers and of money demand commonly used by central banks in more advanced countries.

82. The findings are generally encouraging for the use of econometric models for monetary analysis in Rwanda. Despite serious data limitations, common models yield results that are sufficiently reliable to usefully inform policymaking. Nevertheless, the judgment of policymakers will always remain the pivotal point of monetary policy implementation.

83. On the supply side, the multipliers can be forecast with reasonable reliability. For all multipliers and component ratios, it is possible to construct simple time series models that reduce the residuals to white noise. The aggregate approach to forecasting the multiplier yields somewhat better results than the components approach. Examining the component ratios from the structural side, we can establish the relationships found in studies on industrial economies for the reserve ratio that reflects the behavior of the banks, but not for the ratios reflecting the behavior of the non-bank public.

84. On the demand side, the long-term money demand relationship can be characterized by a cointegrating vector, and for the short-term relationship, a Vector Error Correction Model (VECM) can be fitted well to the actual series (in levels). The long-term relationship includes the price level, real output, and the exchange rate as a proxy of the opportunity cost of holding nominal balances of domestic currency. However, some variables frequently used in long-term money demand models cannot be included due to data problems. The periods of excess money demand or supply resulting from this cointegrating equation can be shown to be intimately associated with discernable shocks. The short-term specification, in addition to the variables in the long-run specification, also includes structural and seasonal dummies.

\section{B. Data}

85. Monetary statistics in Rwanda are broadly adequate for econometric analysis. The National Bank of Rwanda (NBR) publishes its balance sheet and data on its money and foreign exchange market operations, including exchange rates and interest rates, on a weekly, and the banking sector balance sheet on a monthly basis. Format and detail of the information provided conform mostly to generally accepted standards.

\footnotetext{
${ }^{52}$ Prepared by D. Hauner and G. Di Bella, drawing on a draft Working Paper by the authors.
} 
86. Nevertheless, some serious data limitations must be born in mind in the economic interpretation of the statistical results subsequently presented: (a) Most series have several breaks, most importantly due to the war and genocide in 1994. (b) Some series important for our analysis (for example, borrowed reserves) are only available after 1995. (c) Interest rate and exchange rate controls during some periods limited not only the variance of some variables, but also their economic interpretation. ${ }^{53}$ (d) With regard to national accounts, only annual GDP statistics are available and those only for the production side. ${ }^{54}$ (e) For prices, the GDP deflator shares the problems just mentioned, while the consumer price index (CPI) is constrained by its technical implementation and uneven regional coverage.

\section{While we will deal with more specific data issues in the money multiplier and} money demand sections, respectively, we upfront define the monetary aggregates as: The monetary base is currency in circulation outside banks plus bank reserves (including cash in banks) plus non-bank deposits in the NBR, as defined for the IMF program. ${ }^{55}$ The adjusted monetary base is the monetary base excluding borrowed reserves. M1 is currency in circulation plus demand deposits with commercial banks. M2 is M1 plus time and savings deposits with commercial banks. M1 in real terms is M1 in nominal terms deflated by a measure of the price level (either the CPI or the GDP deflator). Currency outside banks in real terms is measured in a similar way.

\section{Limitations on control over the monetary base by the central bank limit not} only the effectiveness of monetary policy, but also the usefulness of monetary control models. In principle, the central bank can control three sources of the monetary base: net foreign assets, net credit to government, and credit to the private sector. The fourth source, other items net, contains assets and liabilities that are mostly outside the direct control of the central bank, such as the counterpart to valuation changes in its net foreign assets. However, net foreign assets are also largely outside the control of the central bank when foreign exchange inflows are uncertain, as in the case of substantial grant flows. The same applies to net credit to government in the case of fiscal dominance, particularly when coordination between the treasury and the central bank is lacking.

\section{The NBR has obtained increasing, albeit still limited, control over the}

monetary base in recent years. Table III-1 shows the annual growth rates of the monetary base from 1995 to 2003, and the respective contributions of the four sources of the base. On the back of higher grant inflows, 2000-2002 permitted a lessening of fiscal dominance,

\footnotetext{
${ }^{53}$ Unfortunately, collection of parallel exchange market data has started only recently.
}

\footnotetext{
${ }^{54}$ Agricultural production is estimated per season (approximately every six months) and the estimates published by the minister of agriculture. However, this series also present voids and some inconsistencies in the methodology used for its compilation.

${ }^{55}$ While non-bank deposits in the central bank do not, strictly speaking, constitute high-powered money, a large part of "non-bank deposits" are deposits by (money-creating) other non-bank financial institutions, most importantly the Union des Banques Populaires Rwandaises (UBPR).
} 
although the year 2003 marked a backslash here. While net credit to the private sector was a minor contributing factor to the growth in the monetary base up to the year 2000, it has gained considerably in importance during recent years.

Table III-1. Sources of the Monetary Base

(Percentage change relative to the beginning-of-period monetary base)

\begin{tabular}{lrrrrr}
\hline Period & B & NFA & NCG & CPS & OIN \\
\hline 1995 & 39.4 & 89.1 & -68.5 & 6.8 & 12.0 \\
1996 & 23.7 & 19.8 & 11.8 & -4.5 & -3.4 \\
1997 & 6.1 & 43.5 & 19.9 & -7.6 & -49.8 \\
1998 & -8.3 & -26.6 & -8.2 & 9.7 & 16.8 \\
1999 & 15.8 & -3.0 & 18.8 & 0.2 & -0.2 \\
2000 & -9.0 & 27.3 & -27.9 & 3.8 & -12.1 \\
2001 & 4.6 & 39.8 & -11.2 & -23.6 & -0.5 \\
2002 & 13.0 & 58.3 & -56.8 & 16.9 & -5.4 \\
2003 & 15.2 & -17.0 & 44.0 & 2.1 & -13.8 \\
\hline
\end{tabular}

Sources: National Bank of Rwanda; authors' calculations.

Notes: B...Monetary Base, NFA...Net Foreign Assets, NCG... Net Credit to Government (credit minus deposits, includes all public entities except for public enterprises), CPS...Credit to Private Sector (includes commercial banks, other financial institutions, and private and public enterprises), OIN...Other Items Net.

\section{Modeling the Money Multipliers}

90. In this section, we examine the scope for modeling Rwanda's money multiplier and its components. First, we introduce the money multipliers and component ratios, including descriptive statistics. Second, we examine whether ARIMA models can forecast the money multipliers with reasonable reliability. Third, we look at whether the component ratios obey the same well-established structural relationships in Rwanda as in many other countries. $^{56}$

91. While the money multiplier approach has come out of fashion in industrial countries, more interest has recently been devoted to it for developing countries. According to classic monetarist theory (for example, Brunner, 1997), the multiplier reflects

\footnotetext{
${ }^{56}$ We limit our analysis in this section to the period after the genocide, i.e., 1995 to 2003, for three reasons: First, we would have to omit the year 1994 due to the lack of data and the exceptional circumstances in this period. Second, many data series are available only for the time after the genocide. Third, substantial interest rate controls limit the usefulness of interest rate data for the time before 1995.
} 
the behavior of the public and of the banks, while the monetary base reflects actions of the central bank. However, most well known studies of the multipliers in industrial countries date back to the 1970 s and $1980 \mathrm{~s},{ }^{57}$ as central banks in industrial and middle-income countries have increasingly shifted from controlling the money stock through reserve aggregates to targeting credit market conditions through interest rates. But in low-income countries, where the estimated interest rate elasticity of money demand is more uncertain, targeting reserve aggregates remains prevalent, ${ }^{58}$ and several papers have been devoted to the money multiplier in developing countries more recently, for example, Darbha (2002), Hasan (2001), and Zaki (1995).

\section{Introducing the money multipliers and component ratios}

92. We use the following concepts: ${ }^{59}$ The monetary base $(\mathrm{B})$ is currency held by nonbanks $(\mathrm{C})$ plus bank reserves $(\mathrm{R})$. The adjusted monetary base (Ba) excludes borrowed reserves. Narrow money (M1) is currency held by nonbanks and demand deposits (D). Broad money (M2) is M1 plus time and savings deposits (T). Four multipliers relate the (adjusted) monetary base to narrow and broad money: $\mathrm{m} 1, \mathrm{~m} 1_{\mathrm{a}}, \mathrm{m} 2$, and $\mathrm{m} 2$ a. The components of the multipliers are the currency ratio $(c=C / D)$, the deposit ratio $(t=T / D)$, and the (adjusted) reserve ratio $\left(r=R /[D+T]\right.$ or $\left.r_{a}=R_{a} /[D+T]\right)$. The multipliers and their components are related as follows (replace $r$ by $r_{a}, m 1$ by $\mathrm{m}_{a}$, and $\mathrm{m} 2$ by $\mathrm{m} 2_{\mathrm{a}}$ for the multipliers based on adjusted bank reserves):

$$
\begin{aligned}
& \mathrm{M} 1=\frac{1+\mathrm{c}}{\mathrm{c}+\mathrm{r}(1+\mathrm{t})} \mathrm{B}=\mathrm{m} 1 * \mathrm{~B} \\
& \mathrm{M} 2=\frac{1+\mathrm{c}+\mathrm{t}}{\mathrm{c}+\mathrm{r}(1+\mathrm{t})} \mathrm{B}=\mathrm{m} 2 * \mathrm{~B}
\end{aligned}
$$

\section{We do not adjust the monetary base for changes in the reserve requirement} ratio. This allows all the effect of changes in the reserve requirement to appear in the r-ratio and, hence, as fluctuations in the multipliers. The multipliers rise when the reserve

\footnotetext{
${ }^{57}$ For example, Beenstock (1989), Frost (1977), Rasche and Johannes (1987), Garfinkel and Thornton (1991). Baghestani and Mott (1997) and Freeman and Kydland (2000) are more recent examples.

${ }^{58}$ Rasche and Johannes (1987) show that the expected utility loss from deviations of actual money around its targeted level in an interest rate regime versus a reserve aggregate regime mostly depends on the uncertainty of the estimated interest rate elasticity versus the variance of the multiplier forecasts.

${ }^{59}$ For the definitions of the monetary aggregates see the data section.
} 
requirement ratio is lowered and fall when the reserve requirement ratio is raised. ${ }^{60}$

94. We use monthly observations from $1 / 1995$ to $12 / 2003$. Descriptive statistics of multipliers and components are in shown in Table III-2. During this period, the M2 multiplier rose by 83.7 percent, an increase entirely due to a 222.9 percent increase in the time deposit ratio. At the same time, the currency ratio declined by 9.3 percent and the reserve ratio declined by 65.4 percent. Obviously, adjusted multipliers that exclude borrowed reserves are more volatile than the unadjusted multipliers.

Table III-2. Descriptive Statistics of the Multipliers and Components

\begin{tabular}{lcccccccc}
\hline & $\mathrm{M} 1$ & $\mathrm{M}_{\mathrm{a}}$ & $\mathrm{m} 2$ & $\mathrm{~m} 2_{\mathrm{a}}$ & $\mathrm{c}$ & $\mathrm{t}$ & $\mathrm{r}$ & $\mathrm{r}_{\mathrm{a}}$ \\
\hline Mean & 1.58 & 1.62 & 2.74 & 2.82 & 0.66 & 1.19 & 0.19 & 0.18 \\
Median & 1.57 & 1.61 & 2.71 & 2.71 & 0.63 & 1.12 & 0.19 & 0.19 \\
Maximum & 1.90 & 2.17 & 3.66 & 4.24 & 0.99 & 1.83 & 0.34 & 0.34 \\
Minimum & 1.19 & 1.19 & 1.89 & 1.89 & 0.49 & 0.38 & 0.10 & 0.04 \\
Std. Dev. & 0.13 & 0.17 & 0.49 & 0.59 & 0.10 & 0.32 & 0.05 & 0.06 \\
\hline
\end{tabular}

Source: Authors' calculations.

95. Plots of the multipliers and their components are shown in Figure III-1. Both $\mathrm{m} 1$ and $\mathrm{m} 2$ have been trending upwards for most of the sample period (Figures III-1a and III-1b). ${ }^{61}$ The residuals of $\mathrm{m} 1$ and $\mathrm{m} 2$ after detrending and seasonal adjustment (with Census X-12) were smaller in 1999 to 2003 than in 1995 to 1998. The currency ratio has remained relatively stable since 2001, after a precipituous decline from 1995 to 2000 (Figure III-1c). The time deposit ratio trended upward during most of the sample period, but has stabilized somewhat since end-2001 (Figure III-1d). The reserve ratio and the adjusted reserve ratio have trended downward over the sample period, due to the decline in the excess reserve ratio that arguably reflects both the development of better investment opportunities for the commercial banks (government and central bank bills) and the deteriorating solvency of the banking system during the sample period (Figures III-1e and III-1f).

\footnotetext{
${ }^{60}$ An alternative approach would have been to use the reserve adjustment magnitude (RAM) developed by Brunner and Meltzer (see, for example, in Burger and Rasche, 1977, and Frost, 1977). We regard RAM as overly sophisticated for the present context, because the NBR only very rarely changed the reserve requirement in past years, and our concern here is mostly the short-run predictability of the multipliers. Ex post, the ARIMA results below support this decision, as the longest lag in the preferred model for the r-ratio is only an MA(1) term.

${ }^{61}$ The downward spike at the beginning of 1997 reflects an extremely abrupt expansion in the monetary base (through NCG and NFA at a time) during that period.
} 
Figure III-1. The Multipliers and their Components

(a) Multiplier m1 (detrended and seasonally adjusted)
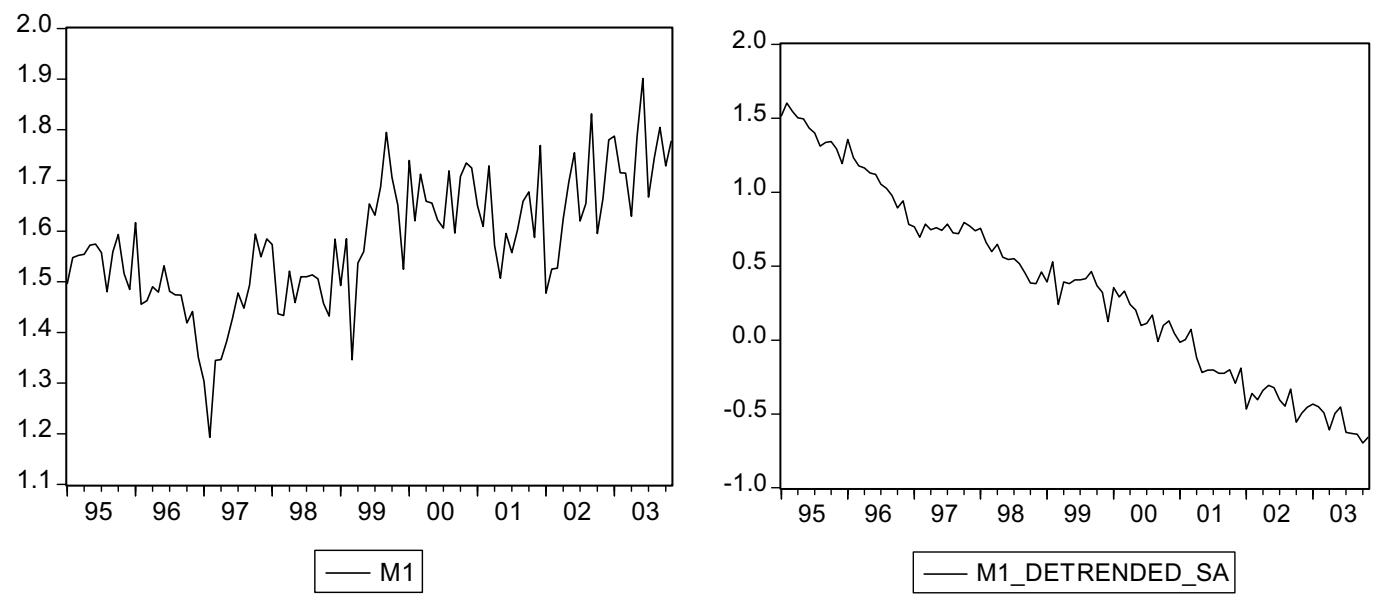

(b) Multiplier $\mathrm{m} 2$ (detrended and seasonally adjusted)

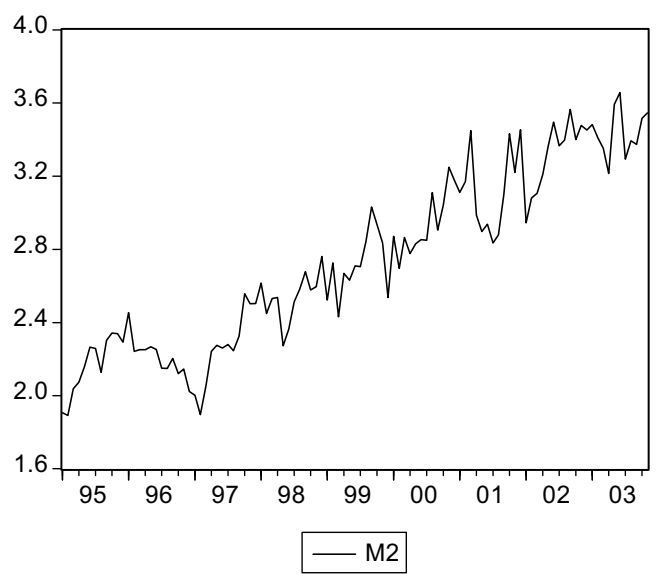

(c) Currency Ratio

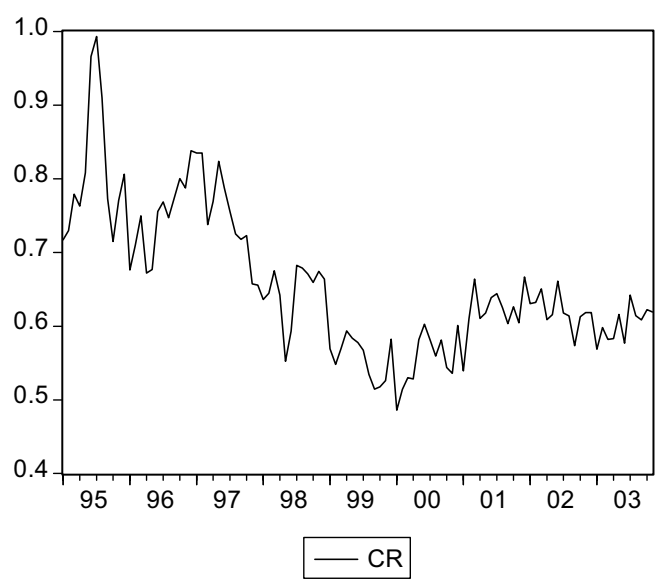

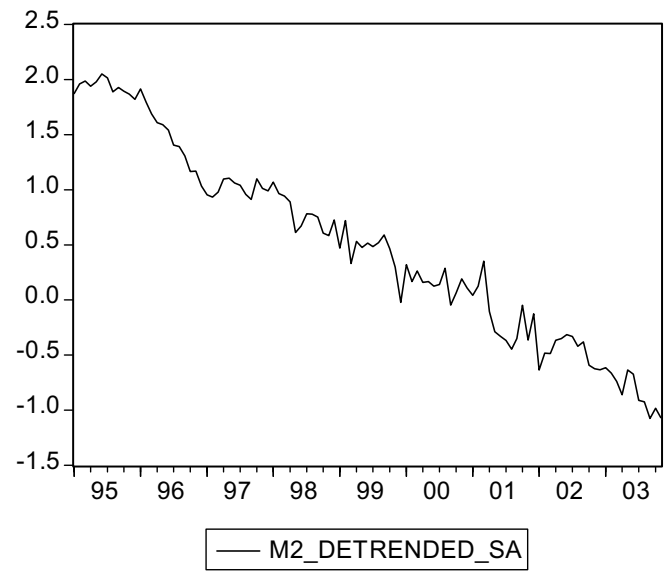

(d) Time Deposit Ratio

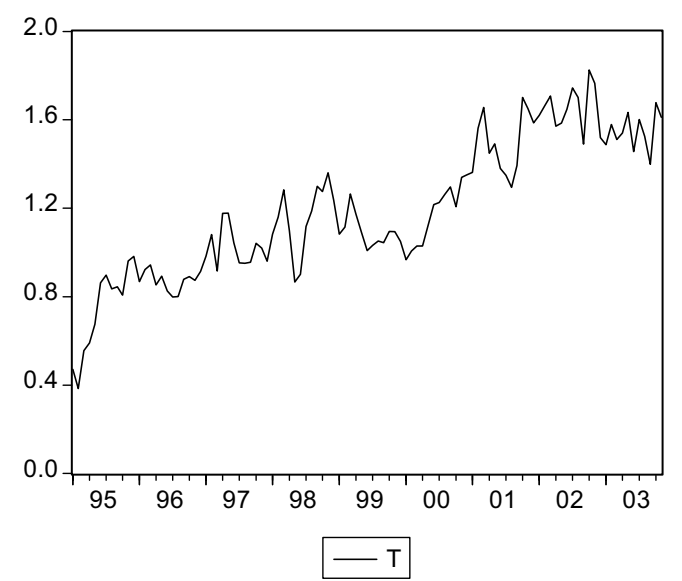


(f) Reserve Ratio

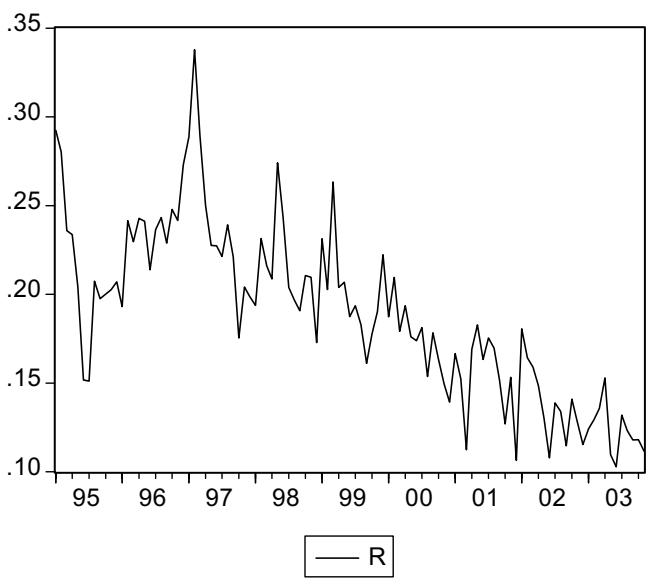

(g) Excess Reserve Ratio

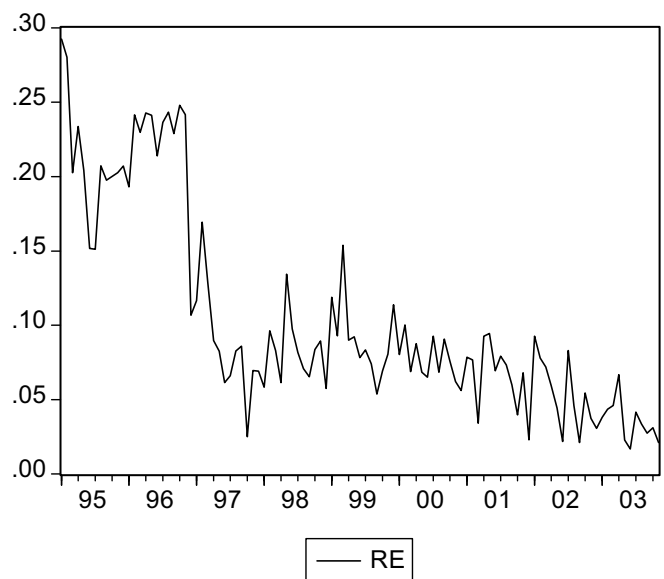

Sources: National Bank of Rwanda; authors' calculations.

96. Regressing the multipliers on their components (Table III-3) suggests that the reserve ratio causes most of the volatility in the multipliers. This crude measure (serial correlation in the residuals is ignored) also shows that volatility in the deposit ratio $t$ accounts for some of the volatility in the $\mathrm{m} 1$ multiplier, but is insignificant for the $\mathrm{m} 2$ multiplier. All significant coefficients have the expected signs.

Table III-3. Sources of Volatility in the Multipliers

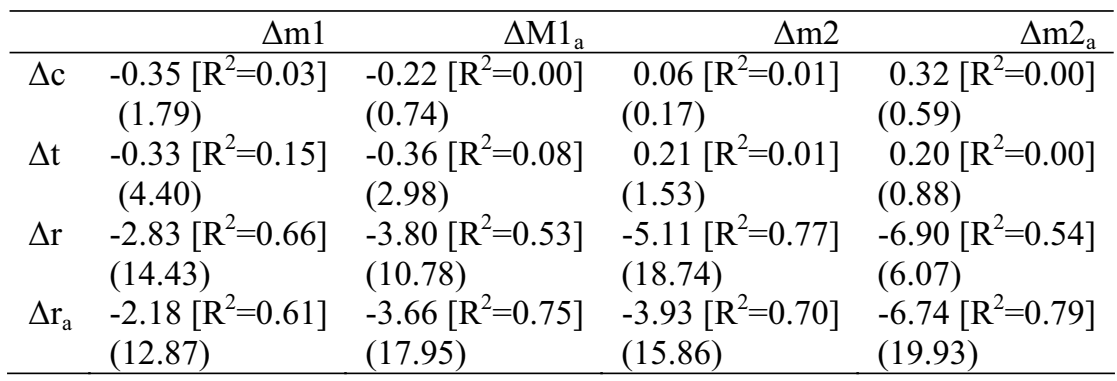

Source: Authors' calculations.

Note: Absolute values of t-statistics are in parentheses.

97. The high contribution of (excess) bank reserves to the volatility of the multiplier has important policy implications. As excess reserves (required reserves are proportional to total deposits and thus rather stable) are at least partly determined by the central bank's policy stance through open market operations, the multipliers cannot be regarded as exogenous with respect to the NBR's policy stance. Thus, policymakers must also predict the effect of their actions on the multiplier when pursuing the multiplier 
approach to money stock control. ${ }^{62}$ Against this background, the central bank should (a) aim to predict the effects of their policy actions on excess reserves and thus on the multiplier, and (b) promote structural measures to reduce the volatility in excess reserves. ${ }^{63}$

\section{ARIMA forecasts of the money multipliers}

\section{We asses the forecast power of ARIMA models of the multipliers and the} component ratios based on the aggregrate (forecast the multipliers directly) vs. the components approach (calculate the multipliers from the forecasts of the components). All the series we examine in this section are integrated of order I(1). As Rasche and Johannes (1984), we do not seasonally adjust the series in order to avoid the introduction of spurious autocorrelation from the standard seasonal adjustment techniques. As yearly seasonal patters in the multipliers can be observed, we followed Box and Jenkins (1976) by including 12month seasonal autoregressive (AR) and moving average (MA) terms in all models; results, however, were inferior to those of other models.

Table III-4. Preferred Models for Multipliers and Components

\begin{tabular}{|c|c|c|c|c|c|}
\hline $\mathrm{y}$ & $\mathrm{p}, \mathrm{d}, \mathrm{q}$ & & & $\mathrm{Q}(24)$ & S.E. \\
\hline $\mathrm{m} 1$ & $9,1,1$ & $\begin{aligned} \mathrm{y}_{\mathrm{t}}= & 0.2849 \mathrm{y}_{\mathrm{t}-9}-0 \\
& (0.1041)\end{aligned}$ & $\begin{array}{c}.5313 \varepsilon_{\mathrm{t}-1}+\varepsilon_{\mathrm{t}} \\
(0.0864)\end{array}$ & 23.7 & 0.0814 \\
\hline $\mathrm{m} 1_{\mathrm{a}}$ & $9,1,1$ & $\begin{aligned} \mathrm{y}_{\mathrm{t}}= & 0.4345 \mathrm{y}_{\mathrm{t}-9}-0 \\
& (0.1017)\end{aligned}$ & $\begin{array}{c}.5839 \varepsilon_{\mathrm{t}-1}+\varepsilon_{\mathrm{t}} \\
(0.0834)\end{array}$ & 25.3 & 0.1126 \\
\hline $\mathrm{m} 2$ & $0,1,1$ & $\begin{array}{r}\mathrm{y}_{\mathrm{t}}=-0.4263 \varepsilon_{\mathrm{t}-1} \\
(0.0884)\end{array}$ & $+\varepsilon_{\mathrm{t}}$ & 22.9 & 0.1469 \\
\hline $\mathrm{m} 2 \mathrm{a}$ & $9,1,1$ & $\begin{aligned} \mathrm{y}_{\mathrm{t}}= & 0.4817 \mathrm{y}_{\mathrm{t}-9}-0 \\
& (0.1003)\end{aligned}$ & $\begin{array}{c}.5801 \varepsilon_{\mathrm{t}-1}+\varepsilon_{\mathrm{t}} \\
(0.0834)\end{array}$ & 18.4 & 0.2068 \\
\hline c & $0,1,2$ & $\begin{array}{r}\mathrm{y}_{\mathrm{t}}=-0.3611 \varepsilon_{\mathrm{t}-2} \\
(0.0906)\end{array}$ & $+\varepsilon_{\mathrm{t}}$ & 20.4 & 0.0434 \\
\hline $\mathrm{t}$ & $0,1,2$ & $\begin{array}{r}\mathrm{y}_{\mathrm{t}}=-0.3782 \varepsilon_{\mathrm{t}-2} \\
(0.0903)\end{array}$ & $+\varepsilon_{\mathrm{t}}$ & 20.3 & 0.1056 \\
\hline $\mathrm{r}$ & $0,1,1$ & $\begin{array}{r}\mathrm{y}_{\mathrm{t}}=-0.3932 \varepsilon_{\mathrm{t}-1} \\
(0.0903)\end{array}$ & $+\varepsilon_{\mathrm{t}}$ & 21.6 & 0.0255 \\
\hline$r_{a}$ & $0,1,1$ & $\begin{array}{r}\mathrm{y}_{\mathrm{t}}=-0.5001 \varepsilon_{\mathrm{t}-1} \\
(0.0829)\end{array}$ & $+\varepsilon_{\mathrm{t}}$ & 21.9 & 0.0305 \\
\hline
\end{tabular}

Source: Authors' calculations.

Notes: Standard errors of coefficients in parentheses. $Q(24)$ is the Ljung-Box statistic at lag 24. S.E. is the standard error of the regression.

\footnotetext{
${ }^{62}$ See Garfinkel and Thornton (1991).

${ }^{63}$ Potential measures include closing the commercial bank accounts at the central bank later in the day, and promoting the interbank market by reducing credit risk through more transparency (for example, an automated book-entry system).
} 
99. For all the multipliers and components, it is possible to construct a simple ARIMA model that reduces the residuals to white noise. ${ }^{64}$ The preferred models are shown in III-Table 4 . The models for $\mathrm{m} 1, \mathrm{~m}_{\mathrm{a}}$ and $\mathrm{m} 2_{\mathrm{a}}$, in addition to the error, each consist of an AR(9) and an MA(1) term. The models for m2, $r$ and $r_{a}$, each consist of only an MA(1) term. The models for $\mathrm{c}$ and $\mathrm{t}$ each consist of only an $\mathrm{MA}(2)$ term.

100. The aggregate approach yields somewhat better results than the components approach. ${ }^{65}$ Comparing their forecasting power in a static (one-step-ahead) forecasting framework, ${ }^{66}$ all diagnostic indicators (III-Table 5) consistently support this finding for all four multipliers defined here. The only two indicators that are better for the components approach are the variance proportion of $\mathrm{m} 1$ and the bias proportion of $\mathrm{m} 2$.

Table III-5. Multipliers Forecast Diagnostics

\begin{tabular}{|c|c|c|c|c|c|c|c|}
\hline & RMSE & MAE & MAPE & TIC & BP & VP & $\mathrm{CP}$ \\
\hline \multicolumn{8}{|c|}{ Aggregate approach } \\
\hline $\mathrm{m} 1$ & 0.0805 & 0.0672 & 4.2869 & 0.0254 & 0.0013 & 0.0305 & 0.9683 \\
\hline $\mathrm{m} 1_{\mathrm{a}}$ & 0.1114 & 0.0885 & & 0341 & & & 0.9694 \\
\hline $\mathrm{m} 2$ & 0.1462 & 0.1121 & & 0.0264 & 20 & 0.0 & 0.9646 \\
\hline $\mathrm{m} 2_{\mathrm{a}}$ & 0.2047 & 0.1556 & & 0.0348 & 0.0030 & 0.0110 & 0.9860 \\
\hline \multicolumn{8}{|c|}{ Components approach } \\
\hline $\mathrm{c}$ & 0.0431 & 0.0322 & 4.9412 & 0.0324 & 0.0014 & 0.0037 & 0.9949 \\
\hline $\mathrm{t}$ & 0.1051 & 0.0821 & & 0.0428 & & & 0.9751 \\
\hline $\mathrm{r}$ & 0.0254 & 0.0199 & 2 & 0.0652 & & 0.0 & 0.9824 \\
\hline $\mathrm{r}_{\mathrm{a}}$ & 0.0304 & 0.0234 & 16.6 & 0.0806 & 0.0 & 0.0 & 0.9757 \\
\hline $\mathrm{m} 1$ & 0.0895 & 0.0729 & & 0.0282 & & & 0.9893 \\
\hline $\mathrm{m} 1_{\mathrm{a}}$ & 0.1263 & 0.0924 & & 0.0387 & 0.0 & & 0.9656 \\
\hline $\mathrm{m} 2$ & 0.1507 & 0.1160 & & 0.0266 & & & 0.9786 \\
\hline $\mathrm{m} 2_{\mathrm{a}}$ & 0.3175 & 0.1974 & 6.2477 & 0.0551 & 0.1238 & 0.1075 & 0.7778 \\
\hline
\end{tabular}

Source: Authors' calculations.

Notes: RMSE is the root mean squared error. MAE is the mean absolute error. MAPE is the mean absolute percent error. TIC is the Theil inequality coefficient. BP, VP and CP are the bias, variance and covariance proportions, respectively. Better forecasts have higher values.

\footnotetext{
${ }^{64}$ We try several models and keep those (i) whose coefficients are all significant at the 1 percent level, and (ii) for which the LM and Ljung-Box tests do not reject the null hypothesis of no serial correlation in the residuals. Among the short-listed models, we use the Akaike and Schwarz criterions to guide us in the selection of the most parsimonous model.

${ }^{65}$ For the United States, Hafer and Hein (1984) came to the same conclusion.

${ }^{66}$ See Hafer and Hein (1984) and Rasche and Johannes (1987) for more elaborate discussions of this approach.
} 
101. In sum, the aggregate approach permits to forecast the multipliers with considerable reliability, particularly for a relatively unsophisticated monetary system. The diagnostic indicators for the aggregate approach (arguably with the exception of the variance proportion in the $\mathrm{m} 1$ and the bias proportion in the $\mathrm{m} 2$ forecasts ${ }^{67}$ ) are all at acceptable levels. However, the diagnostic indicators for the components approach are more mixed. Not surprisingly, the $t$ ratio (which contains also the foreign-currency deposits) and the $r$ and $r_{a}$ ratios prove to be most difficult to forecast. The forecasts of the adjusted multipliers are consistently less robust than those of the unadjusted multipliers. This is not surprising, given the intrinsicly higher volatility of the adjusted multipliers (which exclude borrowed reserves).

102. Two additional factors make us relatively comfortable with our results. First, the differences in the forecast diagnostics between the two approaches are small. This shows that the multipliers in Rwanda's case are no "black boxes" that could potentially hide large unexplainable variations in the multiplier components when analyzed with the aggregate approach. Second, the robustness of the forecasts for Rwanda compares favorably to those found in similar studies of the cases of other other low-income countries (for example, Zaki 1995). ${ }^{68}$

103. The forecast diagnostics of their respective multipliers are ambiguous on the question whether M1 or M2 can be controlled with greater precision. While the mean absolute percent error points to M2, the other scale-invariable indicator, the Theil inequality coefficient, is about the same for M1 and M2. The covariance proportion is slightly lower for M1, where M1 suffers from a higher variation proportion and M2 from a higher bias proportion. However, as a higher bias proportion is arguably more problematic than a higher variance proportion, M1 would be preferred over M2 for monetary targeting.

\section{Explaining the M2 component ratios by structural models}

104. In this section, we broadly apply Beenstock's (1989) framework for the United Kingdom to the structural analysis of the M2 component ratios in Rwanda. However, we are somewhat restricted by data availability. There is, for instance, no reliable measure of velocity to include as an independent variable, as we do not have quarterly, but only annual, observations for GDP.

105. The currency ratio and the time deposit ratio do not seem to behave in line with relationships well-established in other (more advanced) economies. Usually, the currency ratio (time deposit ratio) can be shown to be decreasing (increasing) in income and in the deposit rate. However, for Rwanda we cannot establish this relationship in regressions

\footnotetext{
${ }^{67}$ The variance proportion tells us how far the variation of the forecast is from the variation of the actual series, while the bias proportion tells us how far the mean of the forecast is from the mean of the actual series.

${ }^{68}$ Obviously, the robustness of money multiplier forecasts for a low-income country cannot favorably compare to those for industrial countries (for example, Rasche and Johannes, 1987).
} 
of the currency ratio and the time deposit ratio on GDP and the 3-month deposit rate, which reflects the opportunity cost of holding currency vs. time deposit balances (demand deposits are typically unremunerated in Rwanda), and between demand deposits and time deposits, respectively. That is, economic agents seem to choose between currency vs. demand deposits and demand deposits vs. time deposits independently of income and of the opportunity cost of holding currency and (usually unremunerated) demand deposits vs. time deposits.

\section{The reserve ratio behaves well in line with the results generally found for} advanced economies. The demand for excess reserves (only they are genuinely determined by the banks) is likely to increase with the mean and the variance of the frequency distribution of withdrawals. It is thus expected to vary inversely with the t-ratio, that is, with the share of time deposits in total deposits, because withdrawals from time deposits require advance notification (unless a penalty is paid), and the variance of time deposits is therefore usually lower. The tightness of the NBR's money market policy is likely to affect the demand for reserves. If the central bank assisted the market through its "front window", that is, at market rather than penalty rates, the banks' demand for reserves would tend to fall. ${ }^{69}$ To capture this effect, we use Howard's (1982) variable PEN, defined by

$$
\mathrm{PEN}=\text { discount rate } \bullet \frac{\text { outstanding discount window borrowing from the NBR }}{\text { cash reserves of the banking system }} \text {. }
$$

However, as Howard, we do not find PEN to be significant. As an alternative (and arguably more parsimonious) indicator for the NBR's money market policy stance, we include the discount rate in the model and find it to be highly significant. Since $r$ is naturally constrained between zero and unity, we estimate the model:

$$
\begin{array}{rlr}
\ln (\mathrm{r} /(1-\mathrm{r}))_{\mathrm{t}}=-0.90+0.32 \ln (\mathrm{r} /(1-\mathrm{r}))_{\mathrm{t}-1}+0.22 \ln (\mathrm{r} /(1-\mathrm{r}))_{\mathrm{t}-2}-0.72 \mathrm{t}_{\mathrm{t}}+0.05 \mathrm{R}_{\mathrm{dis}, \mathrm{t}}, \quad(2.29) & (-3.40) \\
(-2.26) & (2.40) & (2.29) \quad \mathrm{R}^{2}=0.70
\end{array}
$$

where $t$ is the deposit ratio and $\mathrm{R}_{\mathrm{dis}}$ is the discount rate; $\mathrm{t}$-statistics are in parentheses. The reserve ratio behaves well in line with the results generally found for advanced economies. As expected, a higher t-ratio reduces demand for reserves, while a higher discount rate increases demand for reserves. All coefficients are significant at the 1 or 5 percent level.

\section{In sum, structural models can characterize only the reserve ratio with}

reasonable reliability. Forecasting the multiplier by structural equations is unlikely to yield reliable results given the apparent independence of the currency ratio and the time deposit ratio of variables suggested by theory and empirical studies on many other countries. However, there is a statistically sound basis for forecasting the reserve ratio $r$ by a structural

\footnotetext{
${ }^{69}$ For a more detailed exposition of the preceding argument, see Beenstock (1989).
} 
model such as the one suggested by equation (4), combined with the model for $t$ in Table III-4.

\section{Modeling Money Demand}

108. In this section, we examine the scope for modeling Rwanda's money demand both for the long and short terms. For the long-run, we identify a money market equilibrium condition by a cointegrating vector of real money balances, output and the exchange rate. For the short run, money demand is estimated by a vector error correction model (VECM). We use quarterly data for the years 1980 to 2003 . We limit the analysis in this section to M1, since M2 (a) is composed of assets reacting differently to changes in the interest rate, and (b) includes dollar-denominated deposits depending highly on foreign investment projects.

\section{Theoretical framework and cointegration analysis}

109. We assume a standard functional form for real money demand. Thus, real money demand is assumed to be a function of output, $y$ (as a proxy for expenditure), a vector including variables that proxy the opportunity cost of holding money balances, $\psi$, and a vector that includes other variables that influence the demand for real balances, $\zeta$. In the long-run, the money market equilibrium condition can be expressed as

$$
\mathrm{M} 1 / \mathrm{P}=f(y, \psi ; \zeta)
$$

The sign of output is expected to be positive and the sign of the opportunity cost of holding money is expected to be negative.

110. We specify the following variables: Real money balances are the difference between the logs of M1 in nominal terms, $\operatorname{lml}$, and either the GDP deflator (lgdpdef), or the CPI (lcpi), while expenditures are proxied by the log of real GDP $(l g d p r)$. The vector $\psi$, which will be part of the more general VECM, is proxied by the inflation rate, measured either as the log first difference of the GDP deflator (dlgdpdef) or the CPI (dlipc) and the depreciation of the exchange rate (dlerya). In addition, we include structural dummies, one for the period of war and genocide (1993:4-1995:1), dumg, and another to reflect changes in the exchange rate peg or in the exchange rate system, dumer (1990:4-1991:1 and 1995:1$1995: 3^{70}$ ). Dummy variables will also be included to account for seasonal factors (dumq2, dumq3, dumq4).

\footnotetext{
${ }^{70}$ These are the only periods in which the quarterly depreciation rate (on average) was higher than 10 percent.
} 
Table III-6. Variable Specifications

\begin{tabular}{|c|c|c|}
\hline Variable & Definition & Source \\
\hline erya & Quarterly average of the official exchange rate & Rwandese authorities and IFS-IMF \\
\hline erye & end-of period (quarterly) official exchange rate & Rwandese authorities and IFS-IMF \\
\hline eryem & end-of period (quarterly) official exchange rate & Rwandese authorities and IFS-IMF \\
\hline$g d p r$ & $\begin{array}{l}\text { quarterly real GDP, resulting from smoothing the } \\
\text { annual series using a quadratic approximation }\end{array}$ & $\begin{array}{l}\text { Rwandese authorities and Fund staff } \\
\text { calculations }\end{array}$ \\
\hline gdpn & $\begin{array}{l}\text { quarterly nominal GDP, resulting from smoothing } \\
\text { the annual series using a quadratic approximation }\end{array}$ & $\begin{array}{l}\text { Rwandese authorities and Fund staff } \\
\text { calculations }\end{array}$ \\
\hline gdpdef & implicit quarterly deflator from $g d p r$ and $g d p n$ & $\begin{array}{l}\text { Rwandese authorities and Fund staff } \\
\text { calculations }\end{array}$ \\
\hline ipc & end-of period (quarterly) consumer price index & Rwandese authorities and IFS-IMF \\
\hline irate & three-month deposit rate in $\mathrm{RF}$ & Rwandese authorities and IFS-IMF \\
\hline$m 1$ & M1 in nominal terms & Rwandese authorities and IFS-IMF \\
\hline$m 1 p$ & M1 in real terms deflated by the CPI & Rwandese authorities and IFS-IMF \\
\hline cil & Currency outside banks in nominal terms & Rwandese authorities and IFS-IMF \\
\hline cilp & $\begin{array}{l}\text { Currency outside banks in real terms deflated by } \\
\text { the CPI }\end{array}$ & Rwandese authorities and IFS-IMF \\
\hline
\end{tabular}

Figure III-2. The Main Variables of the Money Demand Function
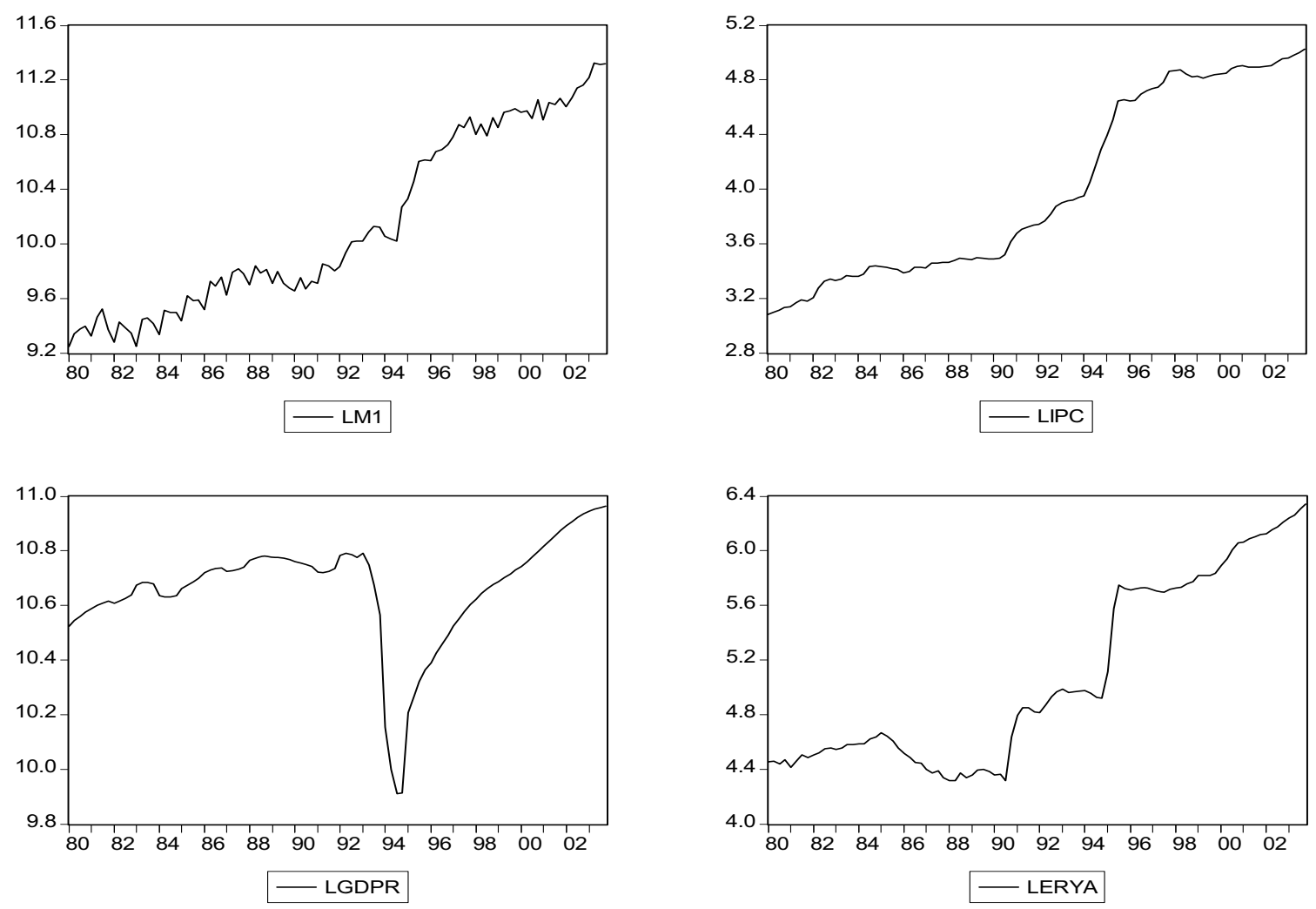

Source: Authors' calculations. 


\section{Figure III-2 shows the evolution (in natural logs) of the variables used in the} estimation. The discrete changes in output and exchange rates are apparent for the moments of political conflict or when there are changes in the policies implemented. Regarding nominal money balances, note how limited the response was during moments of political turmoil: This seems to hint that the adjustment to desired real money balances occurred through the functioning of other adjustment mechanisms, most possibly the inflation rate and exchange rate depreciations, the latter in particular during the second half of the sample. ${ }^{71}$

\section{As we cannot use some variables common for long-run money demand, we} estimate the disequilibrium in the market for real money balances in period $t$ by

$$
\mathrm{E}_{\mathrm{t}}=\operatorname{lm} 1-\beta_{2} \text { lcpi }-\beta_{3} \lg d p r+\beta_{4} \text { lerya, }
$$

where the coefficient on $\operatorname{lm} 1, \beta_{1}$, is normalized to unity. Some papers on money demand (Celasun and Goswami, 2002, among others), include the inflation rate and/or the depreciation of the exchange rate and the interest rate in their formulation of the long-run equilibrium. In the case of Rwanda, this is not possible as these variables are all I(1) in levels. This holds even considering different subsamples. ${ }^{72}$ Furthermore, since the only interest rate (irate) available for most of the period studied, the three-month deposit rate, was under the control of the monetary authorities during an extended period of time, it cannot be used as a genuine measure of the opportunity cost of holding money.

\section{Through the Johansen trace statistic, we find one cointegrating relationship of long-term money demand at the 1 percent significance level and with the expected signs,}

$$
\operatorname{lm} 1-1.13 \text { lcpi }=6.06+1.27 \lg \text { dpr }-0.38 \text { lerya }^{73}
$$

The coefficient of the price level is not significantly different from unity, nor is the coefficient on output at usual confidence levels; this is consistent with a constant velocity in the long run. Note that there is a negative association in the long run between real money balances and the level of the exchange rate. There could be two mutually related reasons for

\footnotetext{
${ }^{71}$ This also seems to indicate difficulties to convert domestic currency into foreign currency as a form to adjust to excesses in money supply; in these cases, the adjustment seemed to have been through exchange rate movements or capital controls.

${ }^{72}$ The null that the first log difference of the GDP deflator (dlgdpdef) has a unit root cannot be rejected at usual significance levels. Building on that, several models using dlgdpdef as a measure of opportunity cost in the cointegrating relationship were tested, some of them with positive results with regard to the economic significance of the coefficients found. However, the goodness of fit was less impressive, in particular for the period after 1998.

${ }^{73}$ Unit-root tests indicate that all the variables considered are I(1). Alternative models combined some of the variables included in (7) with various other variables, including end-of-period instead of quarterly average exchange rates, interest rates, a dummy to account for differences in interest rates regimes, and the consideration of the real money demand as a unique variable forcing the coefficient on the price level to unity.
} 
this: (a) CPI seems to be a good proxy for the prices of non-tradable goods and the price of food staples; (b) the prices of some goods are fully dollarized, regardless whether they are quoted in domestic currency. As a consequence, it seems that the presence of the exchange rate in the cointegrating equation behaves like a shadow price index for tradable goods.

Figure III-3. The Disequilibrium in the Market for Nominal Money Balances

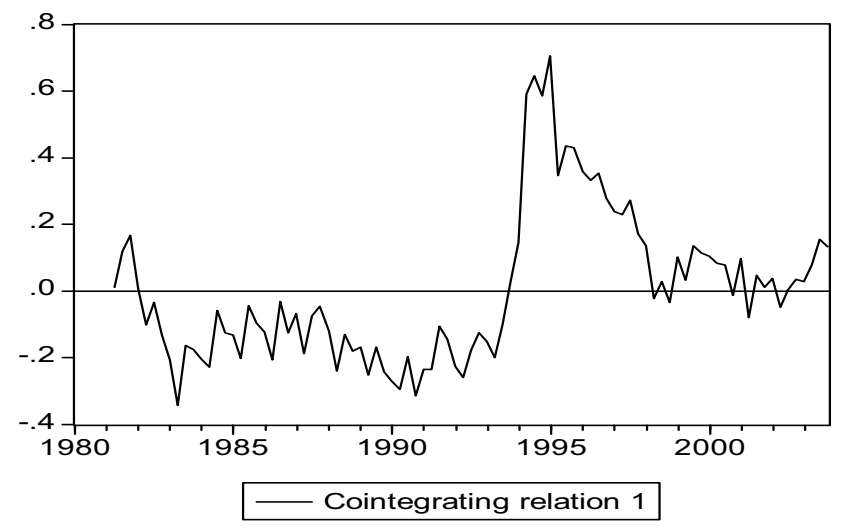

Source: Authors' calculations.

114. The disequilibrium in the market for nominal money balances, $\mathrm{E}_{\mathrm{t}}$, (Figure III-3) shows excess demand for most of the 1980s and a monetary overhang related to the genocide. From (6) it is clear that if $\mathrm{E}_{\mathrm{t}}<0$, there is an excess demand for real money balances. Equilibrium could be restored either through the adjustment of endogenous variables (the price level, the exchange rate level or the level of real income), or through increases in the money supply. (Conversely, if $\mathrm{E}_{\mathrm{t}}>0$, there is an excess supply of real money balances.) Under deteriorating political and economic conditions, the market turned to excess supply during 1994-95 and returned to equilibrium only at the end of the 1990s, since when it has fluctuated around equilibrium. However, the figure shows some monetary overhang at the end of 2003, consistent with what the IMF program review noted at that time.

\section{Short-term demand and VECM}

\section{There are different approaches to model and estimate the demand for real} money balances in the short term. One of these is to integrate the long-run equilibrium condition obtained from the Johansen methodology as one of the terms into a short-term demand in first differences. A more comprehensive approach is to recognize the mutual interaction of the variables included in the money demand specification, and integrate the short-term demand into a more general macroeconometric model such as

$$
\Delta \mathrm{X}_{\mathrm{t}}=\Pi_{0}+\Pi \mathrm{X}_{\mathrm{t}-1}+\Pi_{1} \Delta \mathrm{X}_{\mathrm{t}-1}+\Pi_{2} \Delta \mathrm{X}_{\mathrm{t}-2}+\ldots \ldots .+\Pi_{\mathrm{p}} \Delta \mathrm{X}_{\mathrm{t}-\mathrm{p}}+\Gamma \mathrm{Z}_{\mathrm{t}}+\varepsilon_{\mathrm{t}} .
$$


Here, $\Delta \mathrm{X}_{\mathrm{t}}$ is a $4 \mathrm{x} 1$ vector of $\log$ first differences of the endogenous variables, $\Pi_{0}$ is a $4 \mathrm{x} 1$ vector of constants, $\Pi$ is a $4 \times 4$ matrix including the coefficients (betas) and adjustment coefficient (alphas) of the cointegrating relation, $\mathrm{X}_{\mathrm{t}-1}$ is a $4 \mathrm{x} 1$ vector of the endogenous variables in levels for the period $t-1$, while the rest is composed by lags of $\Delta \mathrm{X}_{\mathrm{t}}$ and their respective matrices of coefficients. Finally, $Z_{t}$ is a vector of exogenous variables and $\varepsilon_{t}$ is a $4 \times 1$ vector of disturbances that are such that $\varepsilon_{\mathrm{it}}$ may be correlated with $\varepsilon_{\mathrm{j} t}$.

\section{We model a VECM in the first differences of the variables considered in the} estimation of the cointegration equation, plus structural and seasonal dummies. Based on the Akaike information criterion and Cholesky decomposition, we proceed to estimate a model with lerya, lgdpr, lcpi, $\operatorname{lm} 1$ and four lags (reducing the sample to 91 observations from 1981:2 to 2003:4). ${ }^{74}$ We use the log first difference of real GDP as the second equation in the VECM because it is often affected by weather-related shocks to the agricultural sector.

\section{The coefficients of the lagged portion of the short-term money demand are} generally in line with economic theory (Table III-7). Output is positively associated with money demand. Price increases precipitate an initial increase of the demand of nominal balances, but a subsequent decrease associated with the need to economize money balances to avoid the inflation tax. In addition, money demand is negatively associated with exchange rate depreciation, which also is the reflection of a higher opportunity cost of holding money.

Table III-7. Lagged Coefficients of Estimated (Short-Term) Money Demand

\begin{tabular}{lrrrr}
\hline Lag & 1 & \multicolumn{1}{c}{2} & \multicolumn{1}{c}{3} & \multicolumn{1}{c}{4} \\
\hline d(lerya) & -0.15 & 0.07 & 0.32 & -0.14 \\
std & -0.14 & -0.15 & -0.14 & -0.12 \\
$\mathrm{t}$ & -1.03 & 0.49 & 2.30 & -1.14 \\
$\mathrm{~d}(\operatorname{lgdpr})$ & 0.39 & 0.52 & -0.46 & -0.20 \\
std & -0.16 & -0.17 & -0.17 & -0.17 \\
$\mathrm{t}$ & 2.41 & 3.05 & -2.76 & -1.17 \\
$\mathrm{~d}(\operatorname{lipc})$ & 0.60 & -0.29 & -0.60 & 0.25 \\
std & -0.35 & -0.38 & -0.38 & -0.32 \\
$\mathrm{t}$ & 1.71 & -0.76 & -1.57 & 0.80 \\
$\mathrm{~d}(\operatorname{lm} 1)$ & -0.30 & -0.12 & 0.03 & 0.29 \\
std & -0.12 & -0.12 & -0.12 & -0.12 \\
$\mathrm{t}$ & -2.47 & -1.02 & 0.28 & 2.47 \\
\hline
\end{tabular}

Source: Authors' calculations.

\footnotetext{
${ }^{74}$ Structural innovations in lerya are assumed to simultaneously affect the innovations in the other variables, while structural innovations in $\mathrm{lm} 1$, do not. This ordering seems reasonable as the exchange rate remained fixed during a significant part of the sample period, and, even after exchange rate liberalization, the central bank continued intervening in the market.
} 


\section{The size and signs found for the seasonal and structural dummies (Table III-8) seem to adequately reflect Rwanda's seasonality and economic circumstances. Money} demand is stronger in the second quarter than in the third and fourth quarters (associated with the agricultural crop cycle), and decreases in the first quarter compared with the fourth. The structural dummies for episodes of rapid depreciation (DUMER) and the genocide period (DUMG) are both positive, reflecting discrete reductions in the demand for nominal money in response to these shocks.

Table III-8. Structural Coefficients of Estimated (Short-Term) Money Demand

\begin{tabular}{lrrrrr}
\hline & DUMER & DUMG & DUMQ2 & DUMQ3 & DUMQ4 \\
\hline Coefficient & 0.02 & 0.08 & 0.11 & 0.05 & 0.05 \\
std & -0.04 & -0.06 & -0.03 & -0.02 & -0.03 \\
$\mathrm{t}$ & -0.60 & 1.38 & 4.19 & 2.91 & 1.90 \\
\hline
\end{tabular}

Source: Author's calculations.

\section{Regarding the long-term equilibrium condition, the associated adjustment} coefficients (alphas, Table III-9) have signs consistent with economic intuition. If $E_{t}>0$, nominal money decreases, while the price level, the exchange rate and real GDP increase to restore equilibrium in the market for real money balances. The alpha for the equation concerning the log first difference of nominal money (the first equation of the VECM) implies that the demand for nominal money balances in the short run will be partially explained by the adjustment towards equilibrium, provided there was disequilibrium in the previous period. Obviously, the magnitude of this disequilibrium changes period to period in response to new innovations. Although this adjustment seems small, it was already hinted by observing the evolution of nominal money balances in Figure III- $4 .{ }^{75}$ The alpha for consumer prices implies that approximately 2 percent per year of the disequilibrium in the market for money is translated into changes in the price level, that is, into positive inflation rates provided there is excess supply in the market for real money balances. The alpha for the exchange rate implies that part of a depreciation occurring in a given year will be partially explained by the adjustment in the market for money (approximately 1 percent of the market's disequilibrium). Real output adjusts more to disequilibria in the money market is, with approximately 8 percent of the disequilibrium per year being transmitted to this variable. ${ }^{76}$

\footnotetext{
${ }^{75}$ In the particular case of Rwanda, the failure of nominal money balances to adjust to disequilibrium in the market for real balances could also be the consequence the existence of dormant accounts in the wake of the genocide.

${ }^{76}$ It is possible that the alphas of the CPI, the exchange rate and M1 are underestimated, as the one of GDP may be overestimated for two reasons. First, a significant part of the variance observed in the GDP series is related to weather-related shocks affecting the agricultural GDP that are, initially, non-monetary in nature; second, the strong recovery in both real money balances and GDP after 1994 may have biased the results.
} 
Table III-9. Long-Term Equilibrium Condition for Money

\begin{tabular}{lrrrr}
\hline & $\mathrm{d}($ lerya $)$ & $\mathrm{d}(\operatorname{lgdpr})$ & $\mathrm{d}(\operatorname{lipc})$ & $\mathrm{d}(\operatorname{lm} 1)$ \\
\hline Coefficient & 0.003 & 0.018 & 0.004 & -0.002 \\
std & -0.004 & -0.004 & -0.002 & -0.006 \\
$\mathrm{t}$ & -0.721 & 5.045 & 2.295 & -0.289 \\
\hline
\end{tabular}

Source: Author's calculations.

120. It is possible to construct a VECM of money demand in levels that fits the actual series well (Figure III-4). Table III-10 shows the nominal money demand in levels resulting from the reduced form of the VECM in levels, blending both short- and long-term estimated portions. The resulting series fits the actual series remarkably well, in particular up to 1997. The larger residuals for the later part of the sample could be, among others, due to a combination of (i) more frequent shocks; (ii) more alternatives to money offered by the banks.

Figure III-4. Actual and Fitted Money Demand

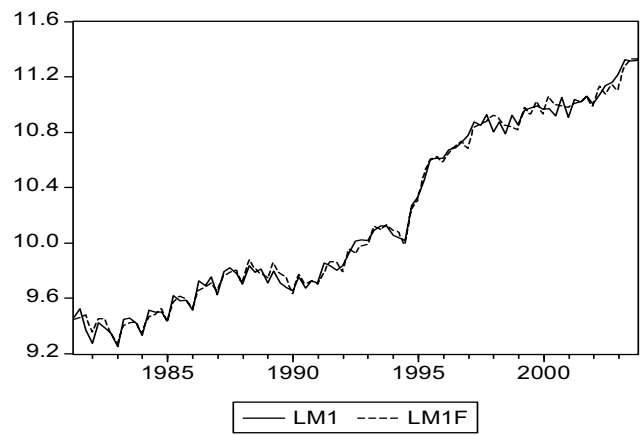

Source: Authors' calculations.

Table III-10. VECM of Money Demand

\begin{tabular}{lrrrrrr}
\hline Lag & & 1 & 2 & 3 & 4 & 5 \\
\hline Constant & -0.11 & & & & & \\
DUMER & 0.03 & & & & & \\
DUMG & 0.08 & & & & & \\
DUMQ2 & 0.11 & & & & & \\
DUMQ3 & 0.05 & & & & & \\
DUMQ4 & 0.05 & & & & & \\
lerya & & -0.15 & 0.22 & 0.25 & -0.46 & 0.14 \\
lgdpr & & 0.41 & 0.13 & -0.98 & 0.26 & 0.20 \\
lipc & & 0.61 & -0.89 & -0.31 & 0.85 & -0.25 \\
$\operatorname{lm} 1$ & & 0.69 & 0.18 & 0.15 & 0.26 & -0.29 \\
\hline
\end{tabular}

Source: Authors' calculations. 
121. A number of potential extensions could complement and improve the analysis of money demand presented here, in particular:

- $\quad$ to distinguish between monetary and non-monetary GDP and to pursue further the effects of weather-related shocks to the agricultural sector; ${ }^{77}$

- $\quad$ to consider a "core CPI" in measuring real money balances, also because core inflation could be a unit root process; ${ }^{78}$

- $\quad$ to compile a series for exchange rate premia in parallel markets for the entire observation period, as black market premia have in the past often been significant;

- $\quad$ to use a structural VECM imposing theory-motivated identification conditions instead of the relatively simple Cholesky approach for the identification of the VECM.

\section{E. Policy Recommendations}

122. Amongst others, our findings suggest the following implications for the NBR's monetary control framework: First, as excess reserves are the main source of volatility in the money multplier, the NBR should favor measures that could stabilize excess reserves. Such measures could include closing the commercial bank accounts at the central bank later in the day and promoting the interbank market by reducing credit risk through more transparency (for example, an automated book-entry system).

\section{Second, The NBR's monetary programming could benefit from paying more} attention to the specification of money demand. The analysis presented here shows that, despite political and economic turmoil, and extensive controls, money demand, both in the short and long terms, reacts in a way consistent with economic fundamentals. Taking this into account when devising its program of interventions in the money market could help the NBR to avoid unwanted monetary overhangs, undesired exchange rate volatility, or bursts in core inflation.

\footnotetext{
${ }^{77}$ Positive shocks could increase the share of the monetized sector (more households achieve a level of production beyond subsistence), and real money demand pressures could arise.

${ }^{78}$ Particularly through food, a significant part of the variance in the CPI is weather-related. Therefore, the cyclical variations observed in the index are mostly the consequence of cyclical changes in food prices generated by a stationary "weather process."
} 


\section{References}

Baghestani, Hamid and Tracy Mott, 1997, "A Cointegration Analysis of the U.S. Money Supply Process,” Journal of Macroeconomics, Vol. 19 (No. 2), pp. 269-83.

Beenstock, Michael, 1989, "The Determinants of the Money Multiplier in the United Kingdom,” Journal of Money, Credit, and Banking, Vol. 21 (No. 4), pp. 464-80.

Box, George E.P. and Gwilym M. Jenkins, 1976, Time Series Analysis: Forecasting and Control (San Francisco: Holden-Day).

Brunner, Karl, 1997, "High-powered money and the monetary base," in: T. Lys (ed.), Monetary Theory and Monetary Policy: The Selected Essays of Karl Brunner (Cheltenham, UK/Northampton, MA: Edward Elgar).

Burger, Albert E. and Robert H. Rasche, 1977, "Revision of the Monetary Base," Federal Reserve Bank of St. Louis Review, Vol. 59 (No. 7), pp. 13-27.

Celasun, Oya, and Mangal Goswami, 2002, "An Analysis of Money Demand and Inflation in the Islamic Republic of Iran,” IMF Working Paper No. 02/205 (Washington: International Monetary Fund).

Darbha, Gangadhar, 2002, "Testing for long-run stability — an application to money multiplier in India," Applied Economics Letters, Vol. 9 (No. 1), p. 33-37.

Freeman, Scott and Finn E. Kydland, 2000, "Monetary Aggregates and Output," The American Economic Review, Vol. 90 (No. 5), pp. 1125-35.

Frost, Peter A., 1977, "Short-run Fluctuations in the Money Multiplier and Monetary Control”, Journal of Money, Credit and Banking, Vol. 9 (No. 1, part 2), p. 165-81.

Garfinkel, Michelle R., and Daniel L. Thornton, 1991, „The Multiplier Approach to the Money Supply Process: A Precautionary Note,“ St. Louis Federal Reserve Bank Review, Vol. 73 (No. 4), pp. 47-64.

Hafer, R.W. and Scott E. Hein, 1984, "Predicting the Money Multiplier: Forecasts from Components and Aggregate Models," Journal of Monetary Economics, Vol. 14 (No. 3), pp. 375-84.

Hasan, Mohammad S., 2001, "The behaviour of the currency-deposit ratio in mainland China," Applied Financial Economics, Vol. 11, pp. 659-68.

Howard, David H., 1982, "The British Banking System's Demand for Cash Reserves," Journal of Monetary Economics, Vol. 9 (No. 1), pp. 21-41. 
Nachega, Jean-Claude, 2000, "Modeling Broad Money Demand in Rwanda", in: IMF, Rwanda-Recent Economic Developments, IMF Staff Country Report No. 00/04 (Washington: International Monetary Fund).

Park, Yung C., 1973, "The Role of Money in Stabilization Policy in Developing Countries," IMF Staff Papers, Vol. 20 (No. 2), pp. 379-418.

Rasche, Robert H. and James M. Johannes, 1987, Controlling the Growth of Monetary Aggregates (Boston: Kluwer Academic Publisher).

Zaki, Mokhlis Y., 1995, "Forecasting the Money Multiplier and the Control of Money Supply in Egypt," The Journal of Development Studies, Vol. 32 (No. 1), pp. 97-111. 


\section{RWANDA'S BANKING SECTOR ${ }^{79}$}

\section{A. Introduction and Summary}

\section{This chapter discusses the structure, performance and problems of Rwanda's} banking system. The sector was severely damaged by the genocide of 1994 and its rebuilding has since then been in the particular focus of the activities of the Fund, the World Bank, and other institutions. ${ }^{80}$ This report is to give an overview of the current state of affairs.

\section{The growing banking sector in Rwanda is relatively limited in size and marked} by significant government intervention. This is despite the emergence of the private sector and the participation of foreign banks. With fast growth of credit to the economy, financial intermediation has developed rapidly, with Rwanda now reaching the average level of financial development in Sub-Saharan African countries of similar income levels.

126. Bank regulation has been strengthened although implementation is problematic. New regulations have been issued at the end of 2003 but the institutional framework for bank supervision and prudential norms can be improved. Implementation of comprehensive bank regulations still faces a number of obstacles and compliance of banks remains uneven.

127. The health of the banking sector remains fragile. Efficiency and profitability of the sector have shown encouraging signs in 2003. However, with a significant share of non performing loans and high risk concentration, asset quality is poor. Capitalization of the sector remains insufficient despite the recent capital injections of the government in two of the six commercial banks.

128. The problems of the banking sector are compounded by their direct links to macroeconomic policy: High and volatile excess reserves render the money multiplier unstable; precarious liquidity situation of several banks impedes monetary policy implementation; and bank restructuring imposes a high quasi-fiscal burden on the economy.

129. The remainder of this chapter is organized as follows. Sections B, C, and D discuss the structure of the sector, its development, efficiency, and profitability, respectively. Section $\mathrm{E}$ gives a brief account of regulation and supervision, while sections $\mathrm{F}$ and $\mathrm{G}$ examine issues of asset quality and capital.

\footnotetext{
${ }^{79}$ Prepared by D. Hauner and J. Vacher (MFD).

${ }^{80}$ Current activities include two long term MFD experts at NBR and the conduct of a World Bank-funded Financial Sector Study completed in June 2004. The scheduling of an FSAP is being discussed with the authorities.
} 


\section{B. Structure of the Sector}

\section{Rwanda's banking sector is of very limited size, and the state retains a} significant stake, despite recent privatizations. At the end of June 2004, Rwanda's banking system had total assets of RF 266 billion (US\$460 million) and total deposits of RF 170 billion (US $\$ 293$ million). Total employment in the sector is approximately 1,800, more than one third of which is accounted for by the association of credit unions (UBPR). Weighted by total assets, the government owned about 45 percent of the banking sector at end-2003. While this number is to fall significantly after the completion of the sale procedure of two state-owned banks, BCR and BACAR, scheduled for the second half of 2004, government involvement will remain significant. Rwandan or international private interests, which have played an increasing role due to the economic boom after the genocide, control most of the rest (Table IV-1).

\section{At end-June 2004, the banking sector consisted of the central bank, the Banque} Nationale du Rwanda (Rwanda National Bank, NBR), six commercial banks, and three special-purpose banks. The commercial banks are (in the order of total assets) Banque de Kigali (BK), Banque de Commerce de Developpement et d'Industrie (BCDI), Banque Commerciale du Rwanda (BCR), Banque à la Confiance d'Or (BANCOR), Banque Continentale Africaine du Rwanda (BACAR), and Compagnie Generale de Banque (COGEBANQUE). BANCOR, BCDI, and COGEBANQUE were established during the economic boom after the 1994 genocide. The sector is dominated by the three largest commercial banks, which account for two thirds of deposits and nearly two thirds of outstanding loans.

\section{The three special-purpose banks are de jure, but not all de facto, delineated} from the commercial banks mainly by their source of funding. In principle, specialpurpose banks do not offer demand deposits. They fund their activities by savings and term deposits of a maturity of at least one year, through own funds and via refinancing facilities for priority sectors managed by the NBR on behalf of the government. This group comprises a development bank (Banque Rwandaise de Developpement, BRD), a mortgage bank (Caisse Hypothecaire du Rwanda, CHR), and 148 cooperative banks that are united in the Union de Banques Populaires de Rwanda (UBPR). UBPR takes demand and time deposits from its members. It differs from other banks by its ownership structure and by a different set of prudential regulations which apply to micro finance activities. ${ }^{81}$ The special-purpose banks play an important role: UBPR's market share, both in deposits and in loans, is larger than those of three of the six commercial banks, while BRD's market share is larger than the one of the smallest commercial banks. However, BRD has a stagnant activity and so far does not fulfill its assigned role of development bank, while CHR, which had been insolvent for many

\footnotetext{
${ }^{81}$ The IMF has recommended on several occasions that the NBR clarify whether the UBPR is or is not a deposit-money bank.
} 
years, received RF 500 million in capital from the government in 2003 and intends to grant housing loans to public servants.

Table IV-1. Overview of Financial Institutions

(End of 2003)

\begin{tabular}{|c|c|c|c|c|c|c|}
\hline & Est. & Ownership & Branches & Staff & \multicolumn{2}{|c|}{ Market share 1/ } \\
\hline & & & & & Deposits & Loans \\
\hline \multicolumn{7}{|c|}{ Commercial banks: } \\
\hline BK & 1966 & $50 \%$ foreign bank, $50 \%$ (para-)statal & 8 & 300 & $26.2 \%$ & $22.6 \%$ \\
\hline BCDI & 1995 & $100 \%$ private & 11 & 245 & $22.2 \%$ & $19.6 \%$ \\
\hline $\mathrm{BCR}$ & 1983 & $100 \%$ (para-)statal 2/ & 7 & 185 & $17.2 \%$ & $15.0 \%$ \\
\hline BANCOR & 1995 & $100 \%$ private & 2 & 50 & $7.3 \%$ & $8.6 \%$ \\
\hline BACAR & 1983 & $66 \%$ (para-)statal, $34 \%$ private $2 /$ & 4 & 160 & $8.3 \%$ & $9.1 \%$ \\
\hline COGEBANQUE & 1999 & $100 \%$ private & 3 & 63 & $3.4 \%$ & $5.1 \%$ \\
\hline \multicolumn{7}{|c|}{ Special purpose banks: } \\
\hline UBPR & 1975 & $100 \%$ private & 149 & 700 & $9.7 \%$ & $12.8 \%$ \\
\hline BRD & 1967 & $\begin{array}{l}33 \% \text { int'l aid agencies, } 11 \% \text { private, } \\
56 \% \text { (para-)statal }\end{array}$ & 1 & 51 & $5.3 \%$ & $7.1 \%$ \\
\hline $\mathrm{CHR}$ & 1975 & $17 \%$ private, $83 \%$ (para-)statal & 1 & 24 & $0.5 \%$ & $0.0 \%$ \\
\hline
\end{tabular}

1/ Balances with non-banks.

2/ After government take-over in 2004, but before the transferral of ownership after privatization.

Sources: Rwandese authorities; BBA(2003).

\section{Development of the Sector}

\section{The state of development of the banking sector is broadly in line with that of} other Sub-Saharan African countries at similar income levels. The 2003 average ratio of broad money to GDP in the countries shown in Table IV-2 was 19.7 percent, compared to 18.5 percent in Rwanda. However, variation in the peer group is very high and the definition of broad money may varie between countries. ${ }^{82}$

\section{A trend of financial deepening could be observed in recent years, accompanied} by rising dollarization. The M2/GDP ratio was highly volatile during 1994-97 due to the genocide and the subsequent strong presence of NGOs and aid agencies. However, it has been trending upward steadily since 1998. More than half of the increase in monetization since 1998 was due to growth in foreign currency deposits (Figure IV-1). These amounted to 4.6 percent of GDP or 31 percent of total deposits at the end of 2003, which is in line with the average for African countries.

\footnotetext{
${ }^{82}$ Rwanda's definition of broad money is very restrictive, that is, its financial depth figure is probably underrather than overstated.
} 
Table IV-2. Ratio of Broad Money to GDP in Selected Countries (in percent)

\begin{tabular}{lrrrr}
\hline & GDP p.c., & & & \\
& USD at PPP, & \multicolumn{3}{c}{ Broad Money in Percent of GDP } \\
\cline { 3 - 5 } & 2003 & 2001 & 2002 & 2003 \\
\hline Chad & 1394.2 & 12.9 & 13.7 & 13.3 \\
Kenya & 1310.1 & 36.0 & 36.2 & 34.9 \\
Burkina Faso & 1200.9 & 20.8 & 19.6 & 19.7 \\
Zambia & 1073.3 & 21.0 & 22.3 & 20.4 \\
Rwanda & 988.1 & 17.3 & 17.6 & 18.5 \\
Niger & 982.1 & 9.6 & 9.0 & 9.6 \\
Malawi & 850.2 & 15.3 & 13.7 & 14.1 \\
Mozambique & 850.2 & 30.6 & 30.5 & 30.0 \\
Tanzania & 726.9 & 13.4 & 14.7 & 16.0 \\
\hline Sourc: & &
\end{tabular}

Source: IMF, World Economic Outlook Database.

\section{An extremely concentrated customer base has lead to fierce competition among}

banks. Only seven percent of the population have bank accounts, most of them with UBPR which has around 350,000 members (BBA 2003). The customer base of commercial banks comprises around 10,000 commercial and 100,000 individual clients. All commercial banks compete both on the deposit and the loan side for a core group of only approximately 50 corporate customers. In addition to a couple of private firms and large public sector entities, this group comprises NGOs, consulates, embassies, and international organizations, which make both foreign exchange deposits and engage in numerous exchange transactions. The fact that only large deposits are remunerated contributes to the banks' dependency on a small group of major depositors.

Figure VI-1. Indicators of Financial Depth

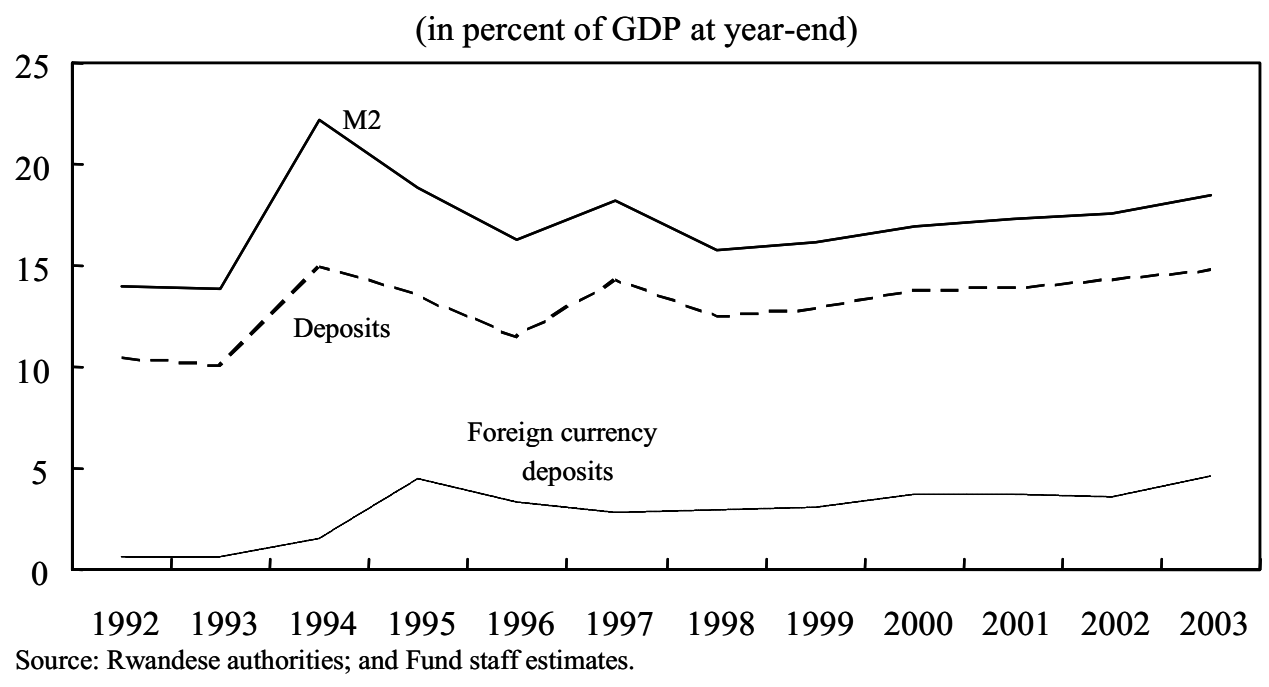


136. Loan-to-deposit ratios are relatively high in Rwanda. At 76 percent in 2003, the overall loan to deposit ratio is close to Kenya's figure of 80 percent. Also, banks in Rwanda hold less government bills than in other countries. While holdings of government paper have been growing rapidly since 2001, they represent only 10 percent of assets (compared with 25 percent in Kenya, 27 percent in Tanzania and 35 percent in Uganda). However, loan to deposit ratios tended to decrease in past years with a rebound in 2003.

137. While credit to the economy has grown rapidly in recent years, provision of credit to the private sector remains narrowly concentrated to Kigali and to specific sectors. A declining government domestic financing requirement permitted credit to the economy to grow twice as fast as nominal GDP since 1994 (Figure IV-2). However, regions and sectors have benefited very unevenly. As much as 80 to 90 percent of banking transactions take place in Kigali. Only UBPR is represented in all of the eleven prefectures. ${ }^{83}$ In terms of sectors, loans go mainly into trade, tourism, property development, and manufacturing. Agriculture, by far the largest sector of the economy, received only 2.3 percent of bank credit in 2003 (compared with about 10 percent in Kenya and 14 percent in Tanzania), notwithstanding the existence of UBPR, which was explicitly charged with provision of credit to the rural areas.

Figure VI-2. Commercial Bank Credit and GDP

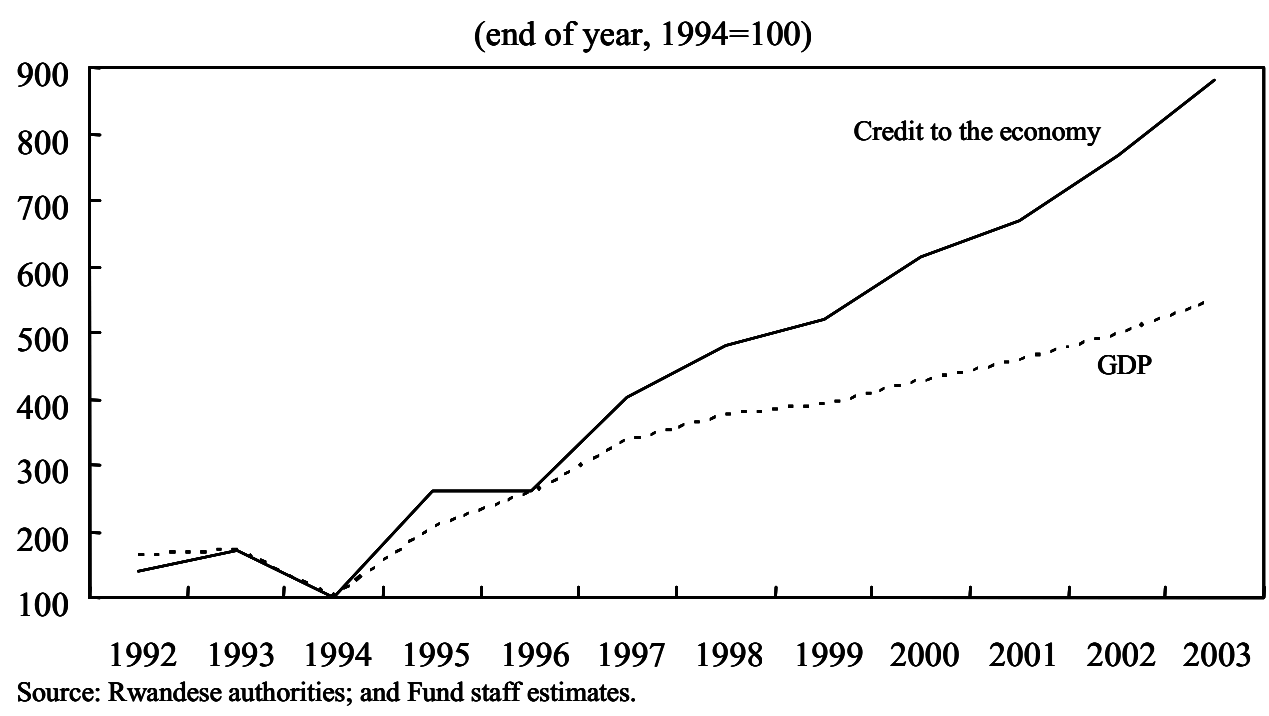

\footnotetext{
${ }^{83} \mathrm{BK}$ and BCDI have each offices in seven prefectures, BCR in six, BACAR in four, and BANCOR in two prefectures. COGEBANQUE is only represented in Kigali.
} 
138. Maturities are very short both for deposits and for loans, against the background of a highly risky environment. Maturities generally do not exceed three months for deposits and one year for loans. There has been some shift away from demand and into fixed deposits in 2001 and 2002, but fixed term deposits came back to 29 percent of total deposits at the end of 2003.

139. Many banks habitually hold high and volatile excess reserves, mainly due to a tenuous money market, among other reasons. More recently, the deterioration in the health of the banking sector reduced excess reserves of the overall system to low and often negative (end-month) levels (Figure IV-3). The overall figure, however, disguises continued high excess reserves of several healthier banks. The main factors accounting for the banks' propensity to keep high working balances appear to be: (a) volatile interbank market that is marked by the perception of high credit risks; (b) limited number of depositors and short maturity of deposits, which imply that management decisions of individual customers can give rise to significant liquidity risks for the banks; (c) closing of accounts with the NBR at the same time as the end of the clearing house session, which is at 12 noon; (d) very high penalties for shortfalls in required reserves that force banks to take strong precautions.

Figure IV-3. Commercial Bank Excess Reserves (RF bn)

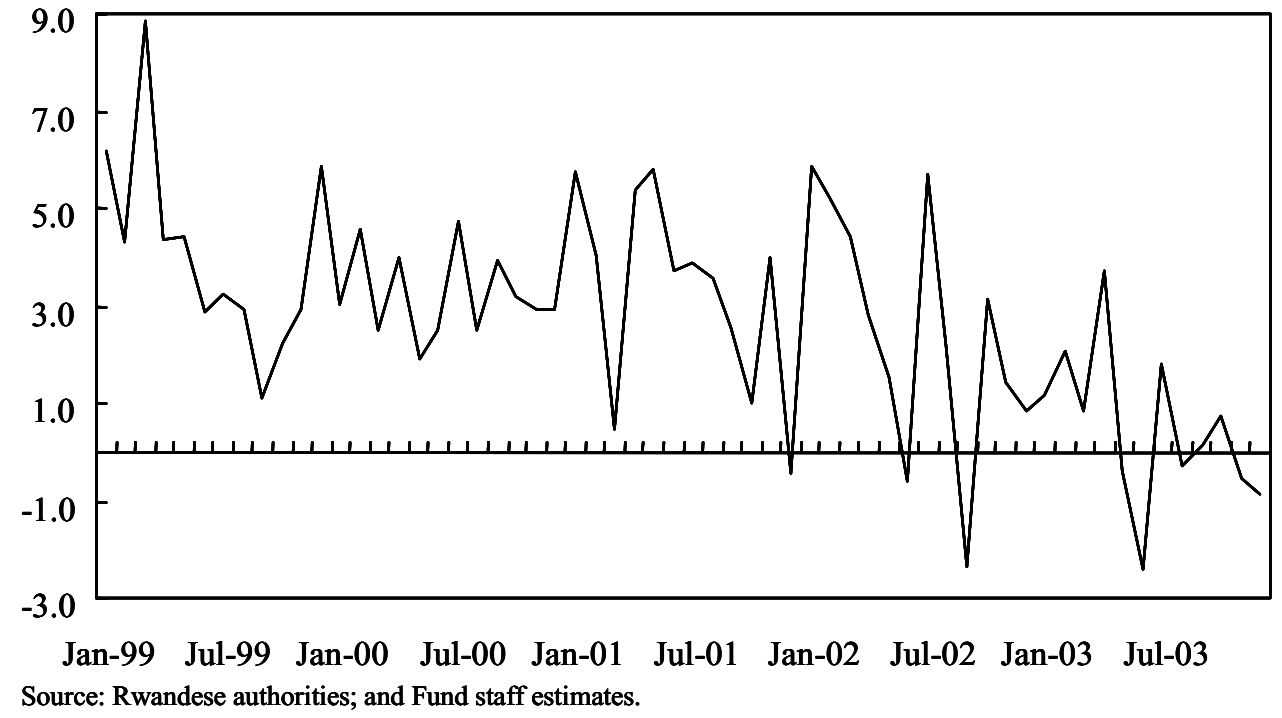




\section{Efficiency and Profitability}

\section{Combined efficiency measures reflect encouraging improvements in 2003}

(Table VI-3). Cost efficiency, which had deteriorated sharply in the preceding years due to high loan-loss provisions, reached its best level in five years. Strong credit growth and high domestic government financing raised revenue and consequently intermediation efficiency ${ }^{84}$ as well as productive efficiency. Compared to other banking sectors of the region, productivity remains low, however (Table IV-4).

141. Profitability improved substantially in $\mathbf{2 0 0 3}$ (Table IV-3). After reaching record lows in 2002 due to high loan-loss provisioning, both return on assets (RoA) and return on equity (RoE) rose markedly in 2003 . This was mainly due to lower provisioning and higher revenues, and partly due to a forceful attempt by some banks to increase loan recovery that will be difficult to repeat. A few caveats have to be mentioned: (a) the RoE measure would have to be adjusted downward by about 20 percent to account for the current capital shortfall relative to required capital in the system (see Table IV-7), (b) the average RoE still masks wide differences between banks. Low interest rate spreads (Table IV $-5^{85}$ ) suggest relatively strong competition in the Rwandese market.

Table IV-3. Performance Ratios

(in percent)

\begin{tabular}{|c|c|c|c|c|c|}
\hline & 1999 & 2000 & 2001 & 2002 & 2003 \\
\hline \multicolumn{6}{|l|}{ Efficiency } \\
\hline Cost efficiency (total expenses/total revenue) & 88.4 & 88.4 & 92.0 & 143.1 & 77.2 \\
\hline Intermediation efficiency (interest expenses/interest revenue) & 32.1 & 34.2 & 35.0 & 37.7 & 34.0 \\
\hline Productive efficiency (salaries/total revenue) & 25.1 & 25.7 & 27.7 & 25.1 & 22.7 \\
\hline \multicolumn{6}{|l|}{ Profitability } \\
\hline RoA (after tax) & 0.6 & 0.6 & 0.3 & -6.5 & 2.3 \\
\hline RoE (after tax) & 5.5 & 4.5 & 2.7 & -84.5 & 34.5 \\
\hline
\end{tabular}

Sources: Rwandese authorities; Fund staff estimates.

Table IV-4. Bank Productivity

(2002, if not stated otherwise; in thousands of US\$)

\begin{tabular}{lcccc}
\hline & Net Interest Per Employee & Assets Per Employee & Loans Per Employee & Deposits Per Employee \\
\hline Kenya & 36 & 581 & 295 & 458 \\
Rwanda (2003) & 17 & 318 & 170 & 224 \\
Tanzania & 25 & 509 & 208 & 279 \\
& & & & 742 \\
Sub Saharan Africa & 49 & 1073 & 505 & 1620 \\
Emerging Markets & 60 & 2040 & 911 & \\
\hline
\end{tabular}

Source: NBR, Staff calculations and Cihak, Podpiera (2004)

Note: excluding UBPR.

${ }^{84} \mathrm{~A}$ low ratio of interest expenses to interest revenue is two-edged: it can indicate high intermediation efficiency of banks, or little competition in the banking market.

${ }^{85}$ Definition of maturities and weighting of loans might differ across countries. 
Table IV -5. Interest Rates, Spreads, and Margins

(2002, unless specified otherwise)

\begin{tabular}{lcccc}
\hline & Real lending rate & Real deposit rate & Interest Spread & Interest margin \\
\hline Kenya & 16.5 & 3.5 & 13.0 & 9.2 \\
Rwanda (2003) & 7.5 & 0.7 & 6.8 & $\ldots$ \\
Tanzania & 12.0 & -1.2 & 13.1 & 7.5 \\
Uganda & 19.4 & 5.9 & 13.5 & 12.7 \\
& & & & \\
Sub-Saharan Africa & 9.9 & -1.5 & 11.5 & 8.1 \\
Low-income countries & 10.8 & -1.6 & 12.4 & 7.8 \\
OECD countries & 4.6 & 0.5 & 4.1 & 3.6 \\
\hline
\end{tabular}

Sources: Cihak and Podpiera (2004), NBR, and Fund staff calculat ions

\section{E. Regulation and Supervision}

142. The current banking law came into force in 1999 and was markedly strengthened by new regulations issued at the end of 2003. The sector was largely liberalized in 1995, including elimination of most restrictions on interest rates. The NBR is responsible for regulation and supervision of the banking system. At the end of 2003, it stepped up prudential regulations by raising the solvency ratio from 8 to 10 percent, lowering the permissible deduction of collateral from loan-loss provisions from 100 to 70 percent, and by strengthening rules on credit concentration, insider lending, and loan management.

143. The prudential regulations in principle conform to generally accepted standards, but important shortcomings remain, most importantly:

- Loan classification is mostly based on past performance, ${ }^{86}$ and allows banks to deduct 70 percent of estimated collateral values from required loan provisions. As deficiencies in the legal infrastructure often impede the sale of collateral, the regulation stipulates that the collateral cannot be deducted from the provisions if it has not been sold after a certain time.

- The NBR's ability to effectively intervene in banks' operations, though its foundations are laid in the banking law, could be strengthened in the following areas: (a) license revocation, (b) removal and/or fining of bank directors and officers, (c) takeover of a bank's management, and (d) liquidation of a bank.

${ }^{86}$ Substandard -90 days, doubtful -180 days and loss -360 days. 
144. Several improvements in the institutional arrangements for banking supervision have been or are currently being implemented:

- The coverage of supervision has been extended. While only three of six commercial banks were audited in 2002, that number was increased to four in 2003 and 2004 (in addition to BRD and CHR). Full annual audits of all six commercial banks are planned to begin in 2005 . Two banks are currently under enhanced supervision.

- $\quad$ A Micro-Finance Supervision Unit was established in 2003.

- A new IAS-based accounting plan for banks took effect in 2004.

- A relaxation of the regulation on the limits on net foreign exchange exposure, that had taken effect in June 2003, was reversed in May 2004.

\section{F. The Problem of Asset Quality}

\section{In spite of recent improvements, asset quality remains the main challenge for} Rwanda's banking sector. At the end of 2003, 30 percent of commercial bank gross loans were nonperforming, 8 percent net of provisions. ${ }^{87}$ This was equivalent to 17 and 4.7 percent of total assets, respectively. Asset quality of some of the special purpose banks is even more problematic. In 2002 and 2003, the share of nonperforming loans (both in total loans and total assets, and both gross and net of provisions), has declined (Figure IV-4, Table IV-6). However, this is partly attributed to strong credit growth that could backfire if the financed projects do not yield the expected results.

146. While the genocide has contributed to a large volume of bad loans, it only explains about one fifth of its present-day total. During the genocide, many borrowers were killed, fled the country, or disappeared. But according to NBR (2002), only 16 percent of total loans on the books at end-June 2002 were contracted before the war, 72 percent of which were nonperforming. Given that total loans at end-June 2002 amounted to 71 percent of total loans at end-2003, bad loans contracted before the genocide amounted to only 8 percent of end- 2003 gross loans $\left(0.16^{*} 0.71 * 0.72=0.08\right)$. These constituted about a quarter of bad loans at end-2003.

\footnotetext{
${ }^{87}$ Nonperforming loans on a gross basis are overstated due to the widespread practice in francophone Africa of carrying them on the books instead of writing them off even when they have been fully provisioned for.
} 
Table IV-6. Banking Sector Balance Sheet

\begin{tabular}{lrrrrr} 
& \multicolumn{6}{c}{ In Percent } & \multicolumn{5}{c}{ of Total Assets/Liabilities \& Equity } \\
\hline & 1999 & 2000 & 2001 & 2002 & 2003 \\
\hline Cash and due from banks & 39.7 & 37.8 & 40.4 & 39.0 & 37.7 \\
Investments & 7.5 & 4.9 & 4.5 & 8.9 & 11.2 \\
Net loans & 52.8 & 46.8 & 46.5 & 43.9 & 43.6 \\
Gross loans & 63.0 & 57.0 & 56.8 & 58.3 & 55.9 \\
$\quad$ Performing loans & 40.1 & 38.1 & 35.8 & 38.6 & 38.9 \\
$\quad$ Non performing loans & 22.8 & 18.9 & 21.0 & 19.6 & 17.0 \\
Loan loss provisions & 10.1 & 10.3 & 10.3 & 14.4 & 12.3 \\
Other assets & 13.3 & 9.3 & 9.0 & 8.9 & 11.9 \\
Demand deposits & 51.5 & 45.5 & 43.6 & 50.1 & 52.0 \\
Time deposits & 23.2 & 19.1 & 25.1 & 27.5 & 21.5 \\
Other liabilities & 24.0 & 21.9 & 19.9 & 19.1 & 21.8 \\
Capital & 14.6 & 12.3 & 11.9 & 4.0 & 9.1 \\
Provisions & 4.1 & 1.7 & 1.6 & 1.2 & 1.6 \\
Reserves & 5.4 & 3.4 & 3.2 & 3.0 & 2.6 \\
Shareholder funds & 4.5 & 7.0 & 7.5 & 7.2 & 9.8 \\
Retained earnings & 0.6 & 0.2 & -0.4 & -7.3 & -5.0 \\
Total off balance sheet items & 124.5 & 105.6 & 85.4 & 88.2 & 77.9 \\
Non-performing in percent of gross loans & 36.3 & 33.1 & 36.9 & 33.7 & 30.3 \\
\hline
\end{tabular}

Sources: Rwandese authorities; Fund staff estimates.

Figure IV-4. Bank Lending and Non-performing Loans

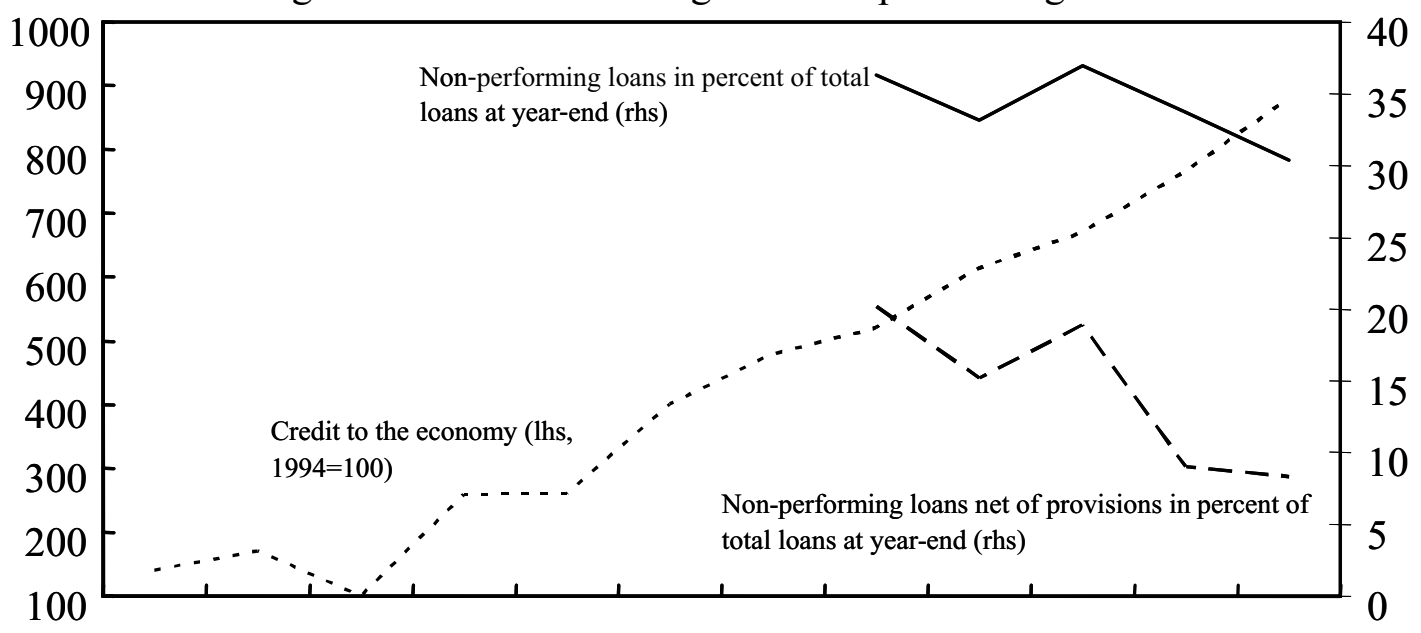

199219931994199519961997199819992000200120022003

Source: Rwandese authorities; and Fund staff estimates. 


\section{Shortcomings of the judicial system and banks' poor management explain the} accumulation of most new nonperforming loans. Many debtors do not meet their obligations even though they are in a position to do so. For instance, NBR (2002) classified 48 percent of nonperforming loans as "capable, but unwilling to pay" at end-June 2002. With respect to banks' management, a study conducted by the Belgian Bankers Association (2003) highlighted the following as areas of particular weakness: strategy and general loan policies; functioning of organizational structure; information systems and management reports; controlling and internal audit; quality of human resources; style of management; and corporate governance.

148. In order to improve loan recovery procedures, measures recently implemented, measures currently being implemented, or measures planned to be introduced, include: ${ }^{88}$

- $\quad$ The voie parée accelerated loan recovery procedure, although temporarily suspended by parliament due to alleged abuses, was reinstituted. Parties can agree on a potential voie parée in the loan agreement. Under such an agreement, the bank can seize the collateral automatically under certain circumstances and safeguards it for the borrower.

- $\quad$ The office of a public notary has been operational since 2001 .

- The creation of financial and commercial courts is ongoing.

- $\quad$ An out-of-court arbitration center has been established and staffed.

- The municipal administration of Kigali has created a registrar of land deeds to facilitate mortgaging.

- $\quad$ The NBR has strengthened its Risks and Unpaid Debts Unit, which centralizes credit information related to delinquent borrowers.

- $\quad$ Since end-2003, banks have not been permitted to lend to borrowers that owe loans in categories three to five. In addition, lenders have to work out restructuring plans with delinquent borrowers, whose names would otherwise be published in newspapers "widely available in the country."

- An action plan for further improvement of credit information quality is to be implemented in 2004.

\footnotetext{
${ }^{88}$ The creation of a "bad bank" for nonperforming loans was considered, but abandoned by the authorities due to concerns that it could give rise to additional moral hazard.
} 
149. Risk concentration is a problem that is difficult to address given the structure of the economy and its lack of diversification. In addition, seasonal derogations have been put in place to take into account the coffee season. Consequently, risk concentration is very likely to continue to impair asset quality. Risk concentration limits appear difficult to implement and are frequently breached by most banks. Overall, the limited development of the private sector, lack of sectoral diversification and limited access to banking services by a large share of population and businesses constitute serious difficulties for regulators.

150. The exposure to foreign-exchange risk is significant and has been growing. At the end of 2003, about 30 percent of assets and liabilities were denominated in foreign currency. Deposits in foreign currency are allowed, with a rising trend in deposit dollarization having somehow stabilized more recently. As lending in foreign currency for domestic operations is not permitted, banks hold foreign assets in correspondent banks. Some of the banks frequently breach the regulatory limits on their net open foreign exchange positions.

\section{G. Capitalization and Restructuring}

151. The sector barely reaches the required solvency ratio. The sectoral capital adequacy ratio at the end of 2003 amounted to only 3 percent ( 0.5 percent at end-2002), while 8 percent would have been required. This shortfall was accounted for by two of the six commercial banks. With the implementation of the new regulation on the capital adequacy ratio, most banks fall short of the new regulatory requirement. The need for provisioning has consistently eroded the capital position of most banks.

\section{Recent capital injections by the government, although potentially giving rise to} additional moral hazard, have alleviated part of the capital shortfall in the system. Recent capital injections by the government in two of the six commercial banks have increased the aggregate capital of the commercial banking system to RF 17.1 billion (Table VI-7). However, if capital is adjusted for nonperforming loans that have not yet been provisioned, the capital shortfall in the system remains significant. While down markedly from end-2002, it still was RF 3.5 billion, or 21 percent of actual capital, at end-2003. ${ }^{89}$

153. Past restructuring attempts could not achieve the sustained improvement of the health of the banking sector. After the genocide, three-year (1996-99) restructuring plans resulted from an audit of the three commercial banks that had existed prior to the genocide and of BRD. While the implementation of these plans was generally satisfactory, many loans granted during the economic revival after the genocide became also nonperforming. A new audit of the financial sector commissioned in 1998 revealed the precarious situation of two banks, for which another restructuring plan (2000-02) was prepared.

\footnotetext{
${ }^{89}$ The latest and provisional data from NBR as of end-June 2004, shows a capital shortfall of RF 5.5 billion. The data do not take into account the results of an inspection report expected to show the need for additional capital in one of the six commercial banks.
} 
Table IV-7. Estimated Capital Shortfall in the Sector (RWF Billion, Unless Specified Otherwise)

\begin{tabular}{|c|c|c|c|c|c|}
\hline & 1999 & 2000 & 2001 & 2002 & 2003 \\
\hline Actual (gross) capital & 15.2 & 16.2 & 17.1 & 6.4 & 17.1 \\
\hline Unprovisioned nonperforming loans & 13.2 & 11.4 & 15.4 & 8.3 & 8.7 \\
\hline Adjusted capital (Actual capitat unprovisioned NPLs) & 2.0 & 4.8 & 1.7 & -1.9 & 8.3 \\
\hline Required capital ( 8 percent of riskweighted assets $1 /)$ & 2.6 & 4.8 & 4.0 & -30.8 & 22.2 \\
\hline Capital shortfall (required adjusted) & 0.6 & 0.0 & 2.3 & -28.8 & 13.9 \\
\hline Capital shortfall in percent of actual capital & 3.8 & 0.0 & 13.6 & -451.5 & 81.4 \\
\hline
\end{tabular}

Sources: Rwandese authorities; Fund staff estimates.

1/ End-2003 figure applies new requirement of 10 percent.

154. While the current restructuring process has been protracted, progress was made more recently. The privatization of BCR and BACAR, planned for 2003, has entered its final phase in July 2004, with buyers selected for each of the banks. For the BRD, a 20032010 strategy was completed in 2002 , giving it the mission to lead poverty reduction measures. A new strategy is being prepared covering 2004-2008. CHR was recapitalized in 2003 , with a capital endowment consisting of government owned houses to be progressively auctioned. The bank is now ready to issue housing loans. 


\section{References}

National Bank of Rwanda (NBR), 2002, Rapport final de la commission interbancaire, Assainisement du portefeuille-credits des etablissements financiers rwandais (Kigali: National Bank of Rwanda).

Belgian Bankers Academy (BBA), 2003, Evaluation du secteur financier rwandais (Brussels: Belgian Bankers Academy).

Cihak, Martin, and Richard Podpiera (2004): "Bank Behavior in Developing Countries: Evidence from East Africa”, draft IMF Working Paper (Washington: International Monetary Fund). 
Table 1. Rwanda: Gross Domestic Product by Origin at Current Prices, 1999-2003

\begin{tabular}{|c|c|c|c|c|c|}
\hline & 1999 & 2000 & 2001 & 2002 & 2003 \\
\hline & \multicolumn{5}{|c|}{ (In billions of Rwanda francs) } \\
\hline GDP at market prices & 644.9 & 705.7 & 754.3 & 825.0 & 905.3 \\
\hline GDP at factor cost & 600.3 & 658.9 & 699.3 & 760.7 & 823.9 \\
\hline Primary sector & 270.4 & 292.3 & 305.2 & 341.6 & 373.9 \\
\hline Food crops & 228.5 & 248.7 & 258.5 & 293.1 & 323.6 \\
\hline Export crops & 2.6 & 2.6 & 2.3 & 2.4 & 2.2 \\
\hline Livestock & 24.4 & 24.9 & 28.3 & 29.7 & 31.4 \\
\hline Other & 9.9 & 11.5 & 12.0 & 12.2 & 12.9 \\
\hline Secondary sector & 124.9 & 144.4 & 163.0 & 175.9 & 192.7 \\
\hline Mining & 1.3 & 11.5 & 14.5 & 9.1 & 5.7 \\
\hline Electricity, gas, and water & 4.2 & 3.7 & 3.4 & 3.4 & 3.6 \\
\hline Manufacturing & 67.8 & 68.6 & 73.9 & 80.5 & 80.3 \\
\hline Construction and public works & 51.5 & 60.5 & 71.2 & 82.9 & 103.1 \\
\hline Tertiary sector & 249.6 & 269.0 & 286.2 & 307.5 & 338.7 \\
\hline Commerce and tourism & 68.7 & 71.0 & 75.2 & 82.0 & 91.7 \\
\hline Transport and communications & 41.8 & 49.7 & 55.1 & 60.7 & 61.7 \\
\hline Public administration & 47.2 & 52.8 & 54.2 & 55.8 & 64.8 \\
\hline \multirow[t]{2}{*}{ Services } & 91.9 & 95.6 & 101.6 & 109.0 & 120.4 \\
\hline & \multicolumn{5}{|c|}{ (In percent of GDP) } \\
\hline Primary sector & 41.9 & 41.4 & 40.5 & 41.4 & 41.3 \\
\hline Of which: food crops & 35.4 & 35.2 & 34.3 & 35.5 & 35.7 \\
\hline export crops & 0.4 & 0.4 & 0.3 & 0.3 & 0.2 \\
\hline Secondary sector & 19.4 & 20.5 & 21.6 & 21.3 & 21.3 \\
\hline Of which: manufacturing & 10.5 & 9.7 & 9.8 & 9.8 & 8.9 \\
\hline Tertiary sector & 38.7 & 38.1 & 37.9 & 37.3 & 37.4 \\
\hline Of which: public administration & 7.3 & 7.5 & 7.2 & 6.8 & 7.2 \\
\hline
\end{tabular}

Sources: Ministry of Finance and Economic Planning; and Fund staff estimates. 
Table 2. Rwanda: Gross Domestic Product by Origin at Constant 1995 Prices, 1999-2003

\begin{tabular}{|c|c|c|c|c|c|}
\hline & 1999 & 2000 & 2001 & 2002 & 2003 \\
\hline & \multicolumn{5}{|c|}{ (In billions of Rwanda francs) } \\
\hline GDP at market prices & 509.8 & 540.3 & 576.6 & 630.7 & 636.7 \\
\hline GDP at factor cost & 474.5 & 504.5 & 534.5 & 581.5 & 579.4 \\
\hline Indirect taxes & 35.3 & 35.8 & 42.0 & 49.2 & 57.2 \\
\hline Primary sector & 223.6 & 243.9 & 264.2 & 302.5 & 293.0 \\
\hline Food crops & 185.3 & 204.5 & 222.4 & 259.3 & 249.9 \\
\hline Export crops & 7.8 & 6.8 & 7.5 & 7.9 & 6.7 \\
\hline Livestock & 21.5 & 22.9 & 24.3 & 25.0 & 25.7 \\
\hline Other & 8.9 & 9.8 & 10.1 & 10.3 & 10.6 \\
\hline Secondary sector & 86.8 & 89.7 & 96.6 & 104.3 & 108.9 \\
\hline Mining & 1.1 & 1.2 & 1.2 & 1.1 & 0.8 \\
\hline Electricity, gas, and water & 1.6 & 1.4 & 1.3 & 1.3 & 1.3 \\
\hline Manufacturing & 48.1 & 46.1 & 49.7 & 52.2 & 49.6 \\
\hline Construction and public works & 36.0 & 41.0 & 44.4 & 49.8 & 57.2 \\
\hline Tertiary sector & 199.5 & 206.6 & 215.8 & 223.9 & 234.7 \\
\hline Commerce and tourism & 48.1 & 47.4 & 49.7 & 52.2 & 55.9 \\
\hline Transport and communications & 34.8 & 39.1 & 41.9 & 44.4 & 42.4 \\
\hline Public administration & 42.8 & 44.1 & 44.6 & 45.0 & 49.5 \\
\hline \multirow[t]{2}{*}{ Services } & 73.7 & 76.0 & 79.5 & 82.2 & 86.9 \\
\hline & \multicolumn{5}{|c|}{ (Annual percent change) } \\
\hline GDP at market prices & 7.6 & 6.0 & 6.7 & 9.4 & 0.9 \\
\hline Primary sector & 8.6 & 9.1 & 8.3 & 14.5 & -3.1 \\
\hline \multirow{2}{*}{$\begin{aligned} \text { Of which: } & \text { food crops } \\
& \text { export crops }\end{aligned}$} & 8.2 & 10.3 & 8.8 & 16.6 & -3.6 \\
\hline & 24.7 & -12.3 & 9.8 & 5.3 & -15.4 \\
\hline Secondary sector & 5.4 & 3.4 & 7.6 & 8.0 & 4.4 \\
\hline Of which: manufacturing & -3.4 & -4.1 & 7.8 & 5.0 & -5.0 \\
\hline Tertiary sector & 7.4 & 3.6 & 4.4 & 3.8 & 4.8 \\
\hline \multirow[t]{2}{*}{ Of which: public administration } & 6.5 & 3.0 & 1.0 & 1.0 & 10.0 \\
\hline & \multicolumn{5}{|c|}{ (In percent of GDP) } \\
\hline \multirow{3}{*}{$\begin{array}{l}\text { Primary sector } \\
\qquad \begin{array}{l}\text { Of which: food crops } \\
\text { export crops }\end{array}\end{array}$} & 43.9 & 45.1 & 45.8 & 48.0 & 46.0 \\
\hline & 36.4 & 37.8 & 38.6 & 41.1 & 39.3 \\
\hline & 1.5 & 1.3 & 1.3 & 1.3 & 1.1 \\
\hline Secondary sector & 17.0 & 16.6 & 16.8 & 16.5 & 17.1 \\
\hline Of which: manufacturing & 9.4 & 8.5 & 8.6 & 8.3 & 7.8 \\
\hline Tertiary sector & 39.1 & 38.2 & 37.4 & 35.5 & 36.9 \\
\hline Of which: public administration & 8.4 & 8.2 & 7.7 & 7.1 & 7.8 \\
\hline
\end{tabular}

Sources: Ministry of Finance and Economic Planning; and Fund staff estimates. 
Table 3. Rwanda: Supply and Use of Resources at Current Market Prices, 1999-2003

\begin{tabular}{|c|c|c|c|c|c|}
\hline & 1999 & 2000 & 2001 & 2002 & 2003 \\
\hline & \multicolumn{5}{|c|}{ (In billions of Rwanda francs) } \\
\hline GDP & 644.9 & 705.7 & 754.3 & 825.0 & 905.3 \\
\hline Consumption & 645.2 & 696.6 & 734.9 & 824.8 & 912.9 \\
\hline Public & 71.2 & 74.3 & 87.9 & 97.7 & 137.1 \\
\hline Private (residual) & 574.0 & 622.4 & 646.9 & 727.1 & 775.7 \\
\hline Domestic investment & 111.1 & 123.7 & 138.9 & 139.6 & 166.8 \\
\hline Government & 40.8 & 42.0 & 50.0 & 40.7 & 51.1 \\
\hline Private & 70.3 & 81.7 & 88.9 & 98.8 & 115.7 \\
\hline Resource gap & -111.4 & -114.7 & -119.4 & -139.3 & -174.4 \\
\hline Exports of goods and nonfactor services & 38.2 & 58.9 & 69.6 & 63.2 & 75.0 \\
\hline \multirow[t]{2}{*}{ Imports of goods and nonfactor services } & 149.6 & 173.5 & 189.0 & 202.5 & 249.4 \\
\hline & \multicolumn{5}{|c|}{ (In percent of GDP) } \\
\hline GDP & 100.0 & 100.0 & 100.0 & 100.0 & 100.0 \\
\hline Consumption & 100.0 & 98.7 & 97.4 & 100.0 & 100.8 \\
\hline Public & 11.0 & 10.5 & 11.7 & 11.8 & 15.1 \\
\hline Private (residual) & 89.0 & 88.2 & 85.8 & 88.1 & 85.7 \\
\hline Domestic investment & 17.2 & 17.5 & 18.4 & 16.9 & 18.4 \\
\hline Government & 6.3 & 6.0 & 6.6 & 4.9 & 5.6 \\
\hline Private & 10.9 & 11.6 & 11.8 & 12.0 & 12.8 \\
\hline Resource gap & -17.3 & -16.3 & -15.8 & -16.9 & -19.3 \\
\hline Exports of goods and nonfactor services & 5.9 & 8.3 & 9.2 & 7.7 & 8.3 \\
\hline Imports of goods and nonfactor services & 23.2 & 24.6 & 25.1 & 24.5 & 27.6 \\
\hline
\end{tabular}

Sources: Ministry of Finance and Economic Planning; and Fund staff estimates. 
Table 4. Rwanda: Supply and Use of Resources at Constant 1995 Prices, 1999-2003

\begin{tabular}{|c|c|c|c|c|c|}
\hline & 1999 & 2000 & 2001 & 2002 & 2003 \\
\hline & \multicolumn{5}{|c|}{ (In billions of Rwanda francs) } \\
\hline GDP & 509.8 & 540.3 & 576.6 & 630.7 & 636.7 \\
\hline Consumption & 503.6 & 529.9 & 547.5 & 606.4 & 617.9 \\
\hline Public & 56.3 & 56.9 & 67.2 & 74.7 & 96.4 \\
\hline Private (residual) & 447.4 & 473.1 & 480.2 & 531.7 & 521.5 \\
\hline Domestic investment & 95.2 & 80.7 & 83.0 & 73.6 & 75.3 \\
\hline Government & 35.0 & 27.4 & 29.9 & 21.5 & 23.1 \\
\hline Private & 60.2 & 53.3 & 53.1 & 52.1 & 52.2 \\
\hline Resource gap & -89.0 & -70.4 & -53.9 & -49.3 & -56.6 \\
\hline Exports of goods and nonfactor services & 39.2 & 42.8 & 59.1 & 57.5 & 56.0 \\
\hline \multirow[t]{2}{*}{ Imports of goods and nonfactor services } & 128.2 & 113.2 & 113.0 & 106.8 & 112.6 \\
\hline & \multicolumn{5}{|c|}{ (In percent of GDP) } \\
\hline GDP & 100.0 & 100.0 & 100.0 & 100.0 & 100.0 \\
\hline Consumption & 98.8 & 98.1 & 95.0 & 96.1 & 97.1 \\
\hline Public & 11.0 & 10.5 & 11.7 & 11.8 & 15.1 \\
\hline Private (residual) & 87.7 & 87.6 & 83.3 & 84.3 & 81.9 \\
\hline Domestic investment & 18.7 & 14.9 & 14.4 & 11.7 & 11.8 \\
\hline Government & 6.9 & 5.1 & 5.2 & 3.4 & 3.6 \\
\hline Private & 11.8 & 9.9 & 9.2 & 8.3 & 8.2 \\
\hline Resource gap & -17.5 & -13.0 & -9.4 & -7.8 & -8.9 \\
\hline Exports of goods and nonfactor services & 7.7 & 7.9 & 10.2 & 9.1 & 8.8 \\
\hline Imports of goods and nonfactor services & 25.1 & 21.0 & 19.6 & 16.9 & 17.7 \\
\hline
\end{tabular}

Sources: Ministry of Finance and Economic Planning; and Fund staff estimates. 
Table 5. Rwanda: Selected Food Crop Production, 1999-2003 (In thousands of metric tons)

\begin{tabular}{|c|c|c|c|c|c|}
\hline & 1999 & 2000 & 2001 & 2002 & 2003 \\
\hline Bananas & 2897.4 & 2150.5 & 2103.1 & 3724.2 & 3223.6 \\
\hline Pulses & 162.1 & 251.5 & 329.7 & 322.7 & 324.7 \\
\hline Beans and cowpeas & 149.3 & 229.2 & 306.0 & 260.5 & 252.9 \\
\hline Soya beans and groundnuts & 12.8 & 22.3 & 23.7 & 62.2 & 71.8 \\
\hline Cereals & 175.0 & 235.4 & 292.9 & 304.3 & 294.0 \\
\hline Sorghum & 107.6 & 155.1 & 174.9 & 184.3 & 170.1 \\
\hline Maize & 54.9 & 62.5 & 92.1 & 91.7 & 80.5 \\
\hline Wheat & 3.6 & 6.4 & 8.2 & 7.4 & 15.2 \\
\hline Rice & 8.9 & 11.4 & 17.7 & 21.0 & 28.2 \\
\hline Roots and tubers & 1445.6 & 2880.7 & 2914.9 & 3484.5 & 3111.4 \\
\hline Irish potatoes & 175.9 & 954.4 & 988.9 & 1038.8 & 1100.0 \\
\hline Sweet potatoes & 862.6 & 1025.6 & 1136.6 & 1291.8 & 864.8 \\
\hline Taro & 90.2 & 88.2 & 101.4 & 122.8 & 138.9 \\
\hline Cassava & 316.9 & 812.5 & 688.0 & 1031.1 & 1007.6 \\
\hline Total & 4680.2 & 5518.1 & 5640.6 & 7835.6 & 6953.7 \\
\hline
\end{tabular}

Source: Ministry of Finance and Economic Planning. 


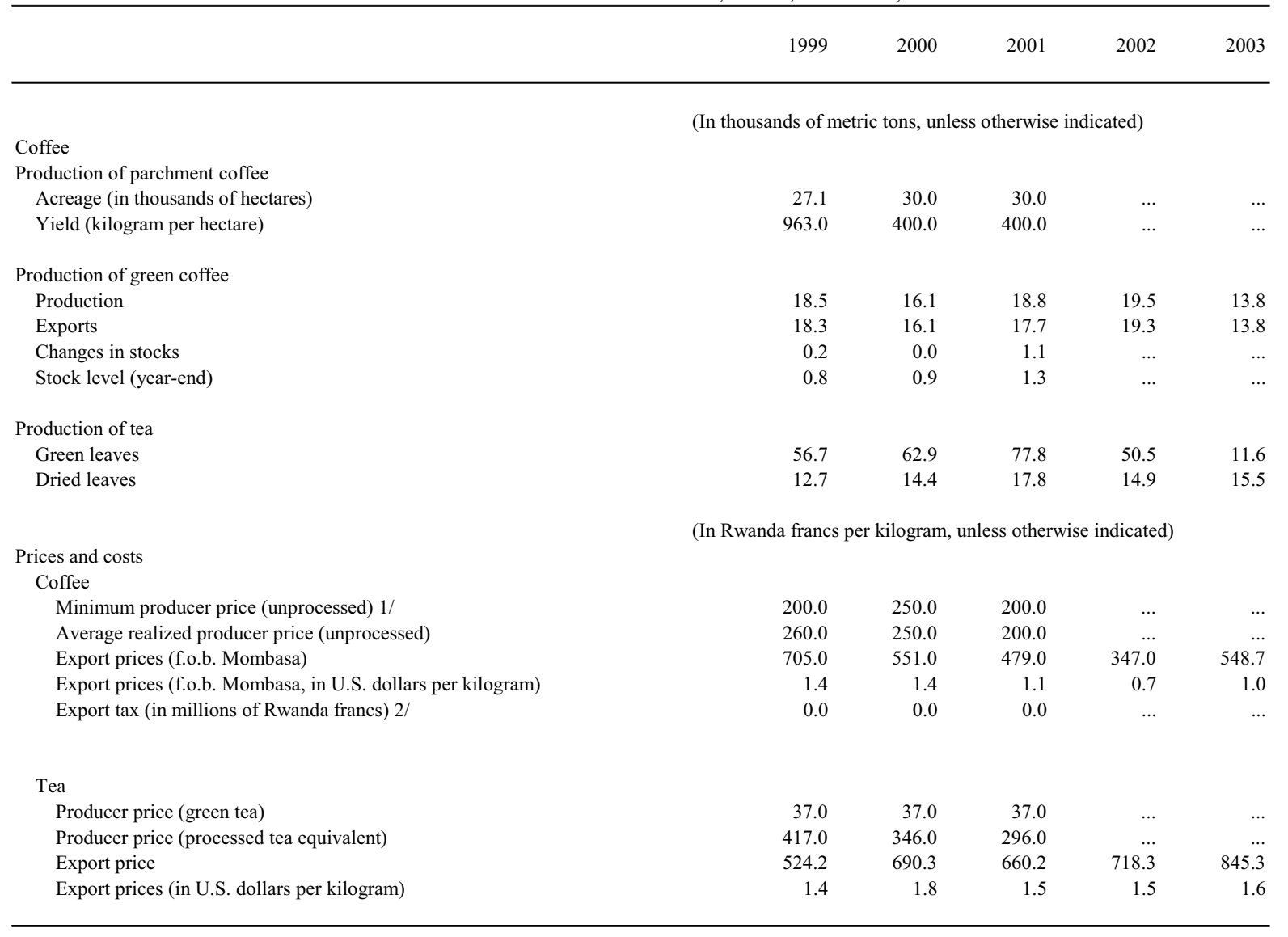

Source: Rwandese authorities.

1/ Since 1996, producer prices have been market determined; in 1997, estimated average producer price.

2/ Up to 1998, the export tax was proportional and based on the f.o.b. Mombasa export price; it was imposed only when the price exceeded US\$0.95 per kilogram. The export tax was abolished in 1999. 
Table 7. Rwanda: Production of Principal Manufactured Goods and Minerals, 1999-2003 (In units indicated)

\begin{tabular}{|c|c|c|c|c|c|}
\hline & 1999 & 2000 & 2001 & 2002 & 2003 \\
\hline \multicolumn{6}{|l|}{ Manufactured goods } \\
\hline Beer (millions of liters) & 59.9 & 44.2 & 47.9 & 53.9 & 41.2 \\
\hline Sugar (metric tons) & 2.1 & 1.1 & 6.3 & 6.6 & 5.3 \\
\hline Soap (tons) & 6431.0 & 5867.0 & 7056.0 & 5571.0 & 4455.5 \\
\hline Corrugated iron sheets (thousands of tons) & 4575.0 & 5435.0 & 4532.0 & 3993.0 & 3513.9 \\
\hline Cigarettes (millions) & 217.0 & 327.0 & 278.0 & 391.0 & 401.8 \\
\hline Textile (millions of meters) & 9.8 & 9.9 & 10.4 & 9.3 & 8.3 \\
\hline Cement (metric tons) & $66,291.0$ & $70,716.0$ & $83,024.0$ & $100,568.0$ & $105,105.4$ \\
\hline \multicolumn{6}{|l|}{ Minerals } \\
\hline Cassiterite (metric tons) & 359.0 & 365.0 & 555.0 & 672.1 & 692.2 \\
\hline Wolfram (metric tons) & 84.0 & 144.0 & 161.0 & 324.7 & 344.5 \\
\hline Colombo-tantalite (metric tons) & 330.0 & 360.0 & 296.0 & 277.0 & 285.3 \\
\hline Gold (kilograms) & 10.0 & $\ldots$ & $\ldots$ & $\ldots$ & $\ldots$ \\
\hline
\end{tabular}

Source: Rwandese authorities. 
Table 8. Rwanda: Energy, Water, and Telephone Production, Consumption, and Prices, 1999-2003

\begin{tabular}{|c|c|c|c|c|c|}
\hline & 1999 & 2000 & 2001 & 2002 & 2003 \\
\hline & \multicolumn{5}{|c|}{ (In millions of kilowatt-hours, unless otherwise indicated) } \\
\hline \multicolumn{6}{|c|}{ 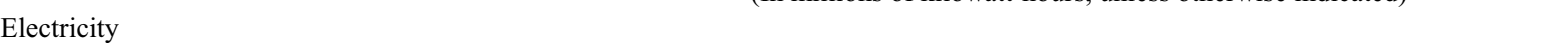 } \\
\hline Available supply & 197.1 & 204.9 & 210.8 & 262.5 & 244.3 \\
\hline Domestic production & 127.3 & 110.8 & 89.3 & 98.2 & 117.6 \\
\hline Imports & 69.9 & 94.1 & 121.5 & 164.3 & 126.7 \\
\hline Number of subscribers (thousands) & 48.4 & 54.0 & 62.0 & 57.7 & 67.0 \\
\hline \multicolumn{6}{|c|}{ Electricity tariff (Rwanda francs per kilowatt-hour) } \\
\hline Low-tension supply & 42.0 & 42.0 & 42.0 & 42.0 & 42.0 \\
\hline \multicolumn{6}{|l|}{ Medium- and high-tension supply } \\
\hline Up to 99 kilowatt-hours & 42.0 & 42.0 & 42.0 & 42.0 & 42.0 \\
\hline Above 100 kilowatt-hours & 42.0 & 42.0 & 42.0 & 42.0 & 42.0 \\
\hline Water & \multicolumn{5}{|c|}{ (In millions of cubic meters, unless otherwise indicated) } \\
\hline Production & 15.3 & 16.3 & 14.4 & 15.3 & 17.2 \\
\hline Consumption & 7.7 & 9.5 & 7.4 & 8.4 & 9.0 \\
\hline Number of subscribers (thousands) & 27.0 & 28.3 & 30.2 & $\ldots$ & 37.3 \\
\hline \multicolumn{6}{|c|}{ Consumption tariff (Rwanda francs per kilowatt-hour) } \\
\hline 0-25 kilowatt-hour & 200.0 & 200.0 & 200.0 & 200.0 & 200.0 \\
\hline 26-60 kilowatt-hour & 300.0 & 300.0 & 300.0 & 300.0 & 300.0 \\
\hline Above 60 and below 100 & 350.0 & 350.0 & 350.0 & 350.0 & 350.0 \\
\hline Above 100 kilowatt-hour & 375.0 & 375.0 & 375.0 & 375.0 & 375.0 \\
\hline \multicolumn{6}{|l|}{ Natural gas } \\
\hline Production & 1353.0 & 1373.0 & 828.0 & 103.0 & 314.3 \\
\hline Consumption & $\ldots$ & $\ldots$ & $\ldots$ & $\ldots$ & $\ldots$ \\
\hline \multicolumn{6}{|l|}{ Telephone } \\
\hline Turnover (in millions of Rwanda francs) 1/ & 5262.0 & 6416.0 & 8914.0 & 9535.1 & $10,599.2$ \\
\hline
\end{tabular}

Source: Rwandese authorities.

1/ Includes only Rwandatel, and the cellular phone company, RWANDACELL. 

(March-June 1982=100)

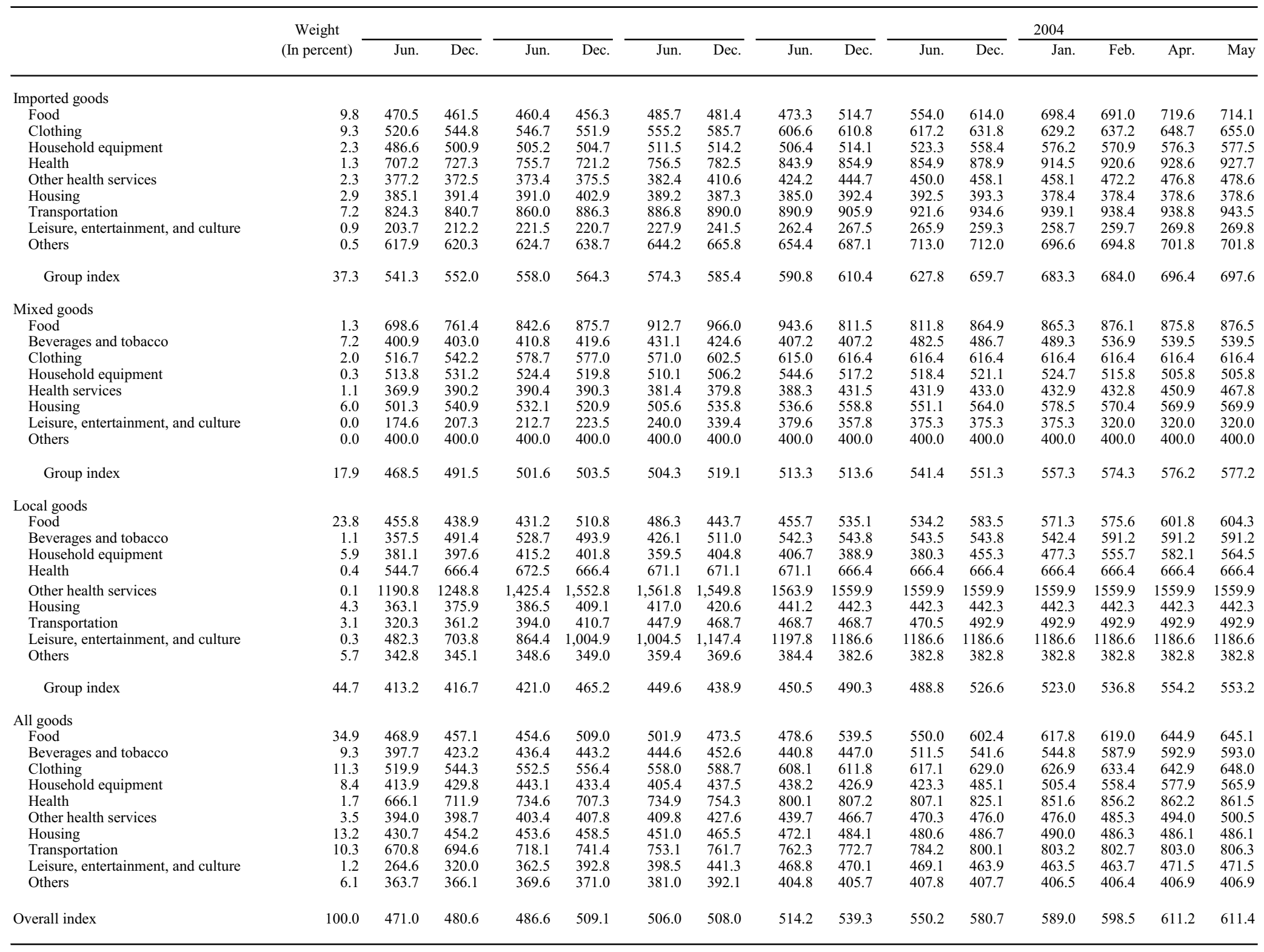

Source: National Bank of Rwanda (NBR). 
Table 10. Rwanda: Budgetary Operations of the Central Government, 1999-2003 (In billions of Rwanda francs)

\begin{tabular}{|c|c|c|c|c|c|}
\hline & 1999 & 2000 & 2001 & 2002 & 2003 \\
\hline Revenue and grants & 100.7 & 136.9 & 148.2 & 160.3 & 195.5 \\
\hline Tax revenue & 60.4 & 65.3 & 79.5 & 94.6 & 114.6 \\
\hline Direct taxes & 15.8 & 18.5 & 24.5 & 30.5 & 35.1 \\
\hline Taxes on goods and services & 33.6 & 35.2 & 41.0 & 47.4 & 57.5 \\
\hline Taxes on international trade & 11.0 & 11.6 & 14.0 & 16.7 & 22.1 \\
\hline Nontax revenue & 3.2 & 3.3 & 6.7 & 6.6 & 7.7 \\
\hline Grants & 37.1 & 68.2 & 62.0 & 59.1 & 73.1 \\
\hline Budgetary grants & 13.4 & 39.9 & 33.9 & 39.3 & 51.0 \\
\hline Of which: HIPC Initiative assistance & 0.0 & 0.0 & 10.6 & 12.2 & 11.5 \\
\hline Capital grants & 23.7 & 28.3 & 28.1 & 19.8 & 22.1 \\
\hline Total expenditure and net lending & 126.5 & 131.7 & 158.1 & 175.9 & 217.8 \\
\hline Current expenditure & 86.0 & 89.2 & 107.4 & 134.6 & 162.7 \\
\hline Of which: priority & 25.1 & 28.5 & 40.1 & 50.4 & 59.1 \\
\hline Wages and salaries & 34.4 & 36.6 & 38.9 & 40.6 & 44.0 \\
\hline Civil & 17.2 & 20.5 & 22.8 & 24.1 & 28.3 \\
\hline Defense & 17.2 & 16.1 & 16.2 & 16.5 & 15.7 \\
\hline Purchases of goods and services & 26.8 & 23.9 & 29.4 & 35.2 & 45.8 \\
\hline Civil & 17.0 & 16.1 & 20.4 & 27.3 & 37.1 \\
\hline Defense & 9.8 & 7.8 & 9.0 & 7.8 & 8.6 \\
\hline Interest payments & 5.4 & 6.5 & 6.2 & 8.3 & 10.5 \\
\hline Domestic debt (due) & 2.4 & 2.0 & 1.3 & 2.1 & 3.2 \\
\hline External debt(due) & 3.0 & 4.5 & 5.0 & 6.2 & 7.3 \\
\hline Transfers (including Rwanda Revenue Authority) & 11.5 & 11.0 & 15.1 & 20.4 & 22.2 \\
\hline Exceptional expenditure & 7.9 & 11.3 & 17.7 & 30.2 & 40.2 \\
\hline Assistance to genocide victims & 3.8 & 4.1 & 5.1 & 4.8 & 5.9 \\
\hline Demobilization/reintegration/reinsertion & 1.9 & 1.8 & 3.4 & 3.4 & 7.3 \\
\hline Education assistance and governance & 2.2 & 3.2 & 5.8 & 7.0 & 5.7 \\
\hline Other & $\ldots$ & 2.1 & 3.3 & 14.9 & 21.3 \\
\hline Capital expenditure & 40.8 & 42.0 & 50.0 & 40.7 & 51.1 \\
\hline Domestic & 5.3 & 1.5 & 3.5 & 6.9 & 13.2 \\
\hline Foreign & 35.5 & 40.5 & 46.5 & 33.8 & 37.9 \\
\hline Net lending & -0.4 & 0.5 & 0.6 & 0.6 & 4.0 \\
\hline Primary deficit (including exceptional expenditure) & -17.0 & -14.1 & -15.0 & -25.2 & -29.8 \\
\hline Primary deficit (excluding exceptional expenditure) & -14.4 & -4.3 & -0.8 & -12.9 & -2.8 \\
\hline \multicolumn{6}{|l|}{ Overall deficit (payment order) } \\
\hline Including grants & -25.8 & 5.1 & -9.9 & -15.6 & -22.3 \\
\hline Excluding grants & -62.8 & -63.1 & -71.9 & -74.8 & -95.4 \\
\hline Change in arrears (net reduction -) & -2.0 & 1.2 & -31.7 & -1.7 & -13.2 \\
\hline Domestic & -4.0 & -1.9 & -15.0 & -3.9 & -1.0 \\
\hline External & 2.0 & 3.0 & -16.7 & 2.2 & -12.1 \\
\hline Discrepancy & -0.2 & 5.5 & 1.0 & 13.5 & -8.2 \\
\hline Deficit (cash basis) & -27.6 & 0.8 & -42.6 & -30.9 & -27.2 \\
\hline \multicolumn{6}{|l|}{ Financing } \\
\hline Foreign financing (net) & 21.5 & 11.4 & 40.9 & 30.5 & 22.0 \\
\hline Drawings & 29.2 & 18.8 & 34.7 & 41.7 & 21.3 \\
\hline Amortization & -11.0 & -10.4 & -9.2 & -14.0 & -15.0 \\
\hline Exceptional financing & 3.3 & 3.0 & 15.4 & 2.8 & 15.7 \\
\hline Of which: HIPC assistance & 0.0 & 0.0 & 0.2 & 0.1 & 0.0 \\
\hline Domestic financing & 6.2 & -12.2 & 1.7 & 0.4 & 5.2 \\
\hline Banking system (monetary survey) & 7.1 & -9.2 & -0.4 & 2.8 & 5.3 \\
\hline Of which: HIPC assistance subaccount $1 /$ & $\ldots$ & $\ldots$ & -3.8 & $\ldots$ & $\ldots$ \\
\hline Nonbank sector (including CSR repayment) 2/ & -0.9 & -3.0 & 2.1 & -2.4 & 0.0 \\
\hline
\end{tabular}

Sources: Ministry of Finance and Economic Planning; and Fund staff estimates.

1/ Assistance from IMF only.

2/ CSR (Caisse Sociale du Rwanda).

CInternational Monetary Fund. Not for Redistribution 
Table 11. Rwanda: Budgetary Receipts, 1999-2003

\begin{tabular}{|c|c|c|c|c|c|}
\hline & 1999 & 2000 & 2001 & 2002 & 2003 \\
\hline & \multicolumn{5}{|c|}{ (In billions of Rwanda francs) } \\
\hline Revenue and grants & 100.7 & 136.9 & 148.2 & 160.3 & 195.5 \\
\hline Total revenue & 63.6 & 68.7 & 86.2 & 101.2 & 122.3 \\
\hline Tax revenue & 60.4 & 65.3 & 79.5 & 94.6 & 114.6 \\
\hline Direct taxes & 15.8 & 18.5 & 24.5 & 30.1 & 35.1 \\
\hline Tax on income and profits & 15.2 & 17.9 & 23.9 & 29.7 & 34.4 \\
\hline Companies & 7.4 & 10.0 & 14.4 & 17.9 & 17.5 \\
\hline Large companies & 6.2 & 9.0 & 12.4 & 14.8 & 13.7 \\
\hline Small enterprises & 1.2 & 1.0 & 2.1 & 3.1 & 3.8 \\
\hline License fees & 0.4 & 0.4 & 0.4 & 0.4 & 0.0 \\
\hline Individuals & 6.1 & 7.5 & 9.0 & 11.1 & 16.5 \\
\hline Others & 1.3 & 0.0 & 0.1 & 0.4 & 0.4 \\
\hline Property taxes & 0.6 & 0.6 & 0.6 & 0.7 & 0.7 \\
\hline Taxes on goods and services & 33.6 & 35.2 & 41.0 & 47.4 & 57.5 \\
\hline Excise taxes & 17.9 & 18.8 & 14.2 & 14.4 & 16.2 \\
\hline Beer & 7.7 & 7.1 & 5.7 & 5.0 & 6.0 \\
\hline Wine and liquor & 0.4 & 0.3 & 0.3 & 0.3 & 0.3 \\
\hline Petrol & 6.7 & 7.9 & 5.5 & 5.9 & 6.5 \\
\hline Cigarettes & 1.0 & 1.4 & 1.2 & 1.6 & 1.7 \\
\hline Lemonade & 2.1 & 2.1 & 1.6 & 1.6 & 1.6 \\
\hline Automobiles & 0.0 & 0.0 & 0.0 & 0.0 & 0.1 \\
\hline Airtime & 0.0 & 0.0 & 0.0 & 0.0 & 0.1 \\
\hline Turnover tax & 12.9 & 13.8 & 24.2 & 29.9 & 38.2 \\
\hline Of which: on imports & 9.0 & 9.4 & 14.6 & 15.5 & 19.4 \\
\hline Road fund & 2.7 & 2.5 & 2.6 & 3.2 & 3.1 \\
\hline Taxes on international trade & 11.0 & 11.6 & 14.0 & 16.7 & 22.1 \\
\hline Export tax & 0.0 & 0.0 & 0.0 & 0.0 & 0.0 \\
\hline Import tax & 8.4 & 9.3 & 11.1 & 12.9 & 18.0 \\
\hline Other & 2.6 & 2.4 & 2.9 & 3.8 & 4.1 \\
\hline Nontax revenue & 3.2 & 3.3 & 6.7 & 6.6 & 7.7 \\
\hline Grants & 37.1 & 68.2 & 62.0 & 59.1 & 73.1 \\
\hline Budgetary grants & 13.4 & 39.9 & 33.9 & 39.3 & 51.0 \\
\hline \multirow[t]{2}{*}{ Capital (project) grants } & 23.7 & 28.3 & 28.1 & 19.8 & 22.1 \\
\hline & \multicolumn{5}{|c|}{ (Annual percent change) } \\
\hline Revenue and grants & 1.7 & 35.9 & 8.3 & 7.9 & 22.3 \\
\hline Total revenue & -3.6 & 7.9 & 25.5 & 16.9 & 21.4 \\
\hline Tax revenue & -3.5 & 8.1 & 21.7 & 18.5 & 21.7 \\
\hline Direct taxes & -13.6 & 17.4 & 32.2 & 22.7 & 16.6 \\
\hline Tax on income and profits & -14.7 & 18.1 & 33.2 & 22.7 & 17.3 \\
\hline Property taxes & 24.8 & -1.1 & 1.2 & 22.3 & -9.8 \\
\hline Taxes on goods and services & 17.8 & 4.7 & 16.7 & 15.5 & 21.2 \\
\hline Excise taxes & 29.9 & 5.1 & -24.5 & 1.1 & 12.9 \\
\hline Turnover tax & 5.9 & 6.6 & 75.4 & 23.5 & 27.8 \\
\hline Road fund & 9.2 & -7.7 & 4.5 & 19.9 & -3.3 \\
\hline Taxes on international trade & -30.3 & 5.5 & 20.1 & 19.7 & 32.3 \\
\hline Export tax & -100.0 & $\ldots$ & $\ldots$ & $\ldots$ & $\ldots$ \\
\hline Import tax & -38.5 & 9.8 & 19.9 & 16.2 & 39.9 \\
\hline Other & 405.8 & -8.8 & 21.0 & 33.7 & 6.8 \\
\hline Nontax revenue & -6.1 & 4.4 & 100.4 & -2.0 & 17.3 \\
\hline Grants & 12.3 & 84.0 & -9.1 & -4.6 & 23.8 \\
\hline
\end{tabular}

Sources: Ministry of Finance and Economic Planning; and Fund staff estimates.

CInternational Monetary Fund. Not for Redistribution 
Table 12. Rwanda: Central Government Expenditure, 1999-2003

(In billions of Rwanda francs) 1/

\begin{tabular}{|c|c|c|c|c|c|}
\hline & 1999 & 2000 & 2001 & 2002 & 2003 \\
\hline General public services & 24.7 & 35.7 & 53.7 & 69.7 & 107.1 \\
\hline National Assemby & 0.5 & 0.8 & 0.8 & 1.0 & 2.0 \\
\hline Vice Presidency 2/ & 0.5 & 0.2 & $\ldots$ & $\ldots$ & $\ldots$ \\
\hline Cabinet of the Prime Miniser & 0.8 & 0.4 & 0.4 & 0.5 & 0.7 \\
\hline Supreme Court & 0.3 & 0.4 & 1.4 & 2.1 & 1.7 \\
\hline Ministry of Interior and Local Development & 1.3 & 3.2 & 4.4 & 5.4 & 6.2 \\
\hline Ministry of Justice & 1.7 & 1.3 & 1.7 & 1.5 & 1.9 \\
\hline Ministry of Civil Service, Labor, and Training & 0.4 & 0.3 & 0.3 & 0.4 & 0.4 \\
\hline Ministry of Finance 3/ & 13.8 & 19.2 & 28.1 & 39.4 & 65.7 \\
\hline \multicolumn{6}{|l|}{ Ministry of Foreign Affairs and International } \\
\hline Cooperation & 3.0 & 2.3 & 2.4 & 2.8 & 2.9 \\
\hline Ministry of Information & 0.6 & $\ldots$ & $\ldots$ & $\ldots$ & $\ldots$ \\
\hline Ministry of Lands, Resettlement, and Environment & 0.2 & 0.1 & 0.4 & 0.8 & 0.6 \\
\hline Ministry of Local Government & 1.1 & 5.1 & 9.0 & 9.4 & 12.7 \\
\hline Defense (Ministry of National Defense) & 29.0 & 25.8 & 28.6 & 36.5 & 24.5 \\
\hline Economic services & 2.6 & 2.1 & 4.9 & 7.5 & 11.9 \\
\hline Ministry of Water and Natural Resources & 0.2 & 0.2 & 0.3 & 0.5 & $\ldots$ \\
\hline Ministry of Agriculture, Husbandry, and Forestry & 1.2 & 1.1 & 1.7 & 1.7 & 1.8 \\
\hline Ministry of Public Works, Transport, and Communications & 0.7 & 0.4 & 2.3 & 4.2 & 9.0 \\
\hline Ministry of Commerce and Industry & 0.5 & 0.4 & 0.6 & 1.0 & 1.0 \\
\hline Social services & 30.3 & 30.5 & 36.2 & 25.2 & 29.7 \\
\hline Ministry of Education & 21.7 & 24.0 & 29.8 & 18.9 & 20.8 \\
\hline Ministry of Youth and Associative Movements & 1.0 & 0.8 & 0.9 & 0.8 & 0.9 \\
\hline Ministry of Family and Social Affairs 4/ & 4.3 & 1.9 & 0.4 & 0.6 & 0.7 \\
\hline Ministry of Health & 3.3 & 3.8 & 5.1 & 4.9 & 7.4 \\
\hline Total & 86.6 & 94.1 & 123.4 & 138.8 & 173.2 \\
\hline
\end{tabular}

Sources: Ministry of Finance and Economic Planning; and Fund staff estimates.

1/ Owing to differences in classifications, aggregates in Tables 10, 12, and 13 differ.

2/ Unit discontinued in 2001.

3/ Includes interest on public debt; excludes amortization and domestic arrears repayments.

4/ In 1999, includes newly created Ministry of Gender. 
Table 13. Rwanda: Functional Classification of Central Government Recurrent Expenditure, 1999-2003 (In billions of Rwanda francs)1/

\begin{tabular}{|c|c|c|c|c|c|}
\hline & 1999 & 2000 & 2001 & 2002 & 2003 \\
\hline General public services & 31.5 & 35.7 & 53.7 & 57.6 & 78.6 \\
\hline Defense2/ & 27.0 & 25.8 & 28.6 & 36.0 & 24.8 \\
\hline Social services & 21.9 & 30.5 & 36.2 & 23.3 & 40.6 \\
\hline Education3/ & 17.2 & 24.0 & 29.8 & 17.2 & 20.2 \\
\hline Health & 3.3 & 3.8 & 5.1 & 4.7 & 7.4 \\
\hline Other & 1.4 & 2.7 & 1.3 & 1.3 & 13.1 \\
\hline Economic services & 2.6 & 2.1 & 4.9 & 6.7 & 8.4 \\
\hline Agriculture & 1.2 & 1.1 & 1.7 & 1.5 & 1.3 \\
\hline Mining and manufacturing & 0.2 & 0.2 & 0.3 & 1.0 & 0.8 \\
\hline Public works4/ & 0.7 & 0.4 & 2.3 & 3.8 & 5.5 \\
\hline Transport and communications 4/ & $\ldots$ & $\ldots$ & $\ldots$ & $\ldots$ & $\ldots$ \\
\hline Other economic affairs & 0.5 & 0.4 & 0.6 & 0.4 & 0.8 \\
\hline Interest payments on public debt & 4.0 & 1.8 & 2.8 & 8.3 & 10.5 \\
\hline Total current expenditure & 87.1 & 95.9 & 126.2 & 131.9 & 162.8 \\
\hline
\end{tabular}

Sources: Ministry of Finance and Economic Planning; and Fund staff estimates.

1/ Owing to differences in classifications, aggregates in Tables 10, 12, and 13 differ.

2/ In 1997, includes RF 1.0 billion for exceptional expenditure for demobilization and RF 0.8 billion for transfers.

3/ In 1997, includes transfers to the University of Rwanda.

4/ In 1999, public works and transport and communications were merged into one ministry. 
Table 14. Rwanda: Priority Expenditure, 1999-2003 (In billions of Rwanda francs)

\begin{tabular}{|c|c|c|c|c|c|}
\hline & 1999 & 2000 & 2001 & 2002 & 2003 \\
\hline Total priority expenditure (recurrent, including University of Rwanda (UNR)) & 25.1 & 28.5 & 40.1 & 50.4 & 59.1 \\
\hline Wages and salaries (excluding UNR) & 13.1 & 14.5 & 17.5 & 19.2 & 22.3 \\
\hline Goods and services (excluding UNR) & 5.1 & 7.2 & 12.3 & 16.9 & 20.8 \\
\hline Transfers & 6.9 & 6.9 & 10.3 & 14.3 & 16.0 \\
\hline UNR & 3.2 & 3.0 & 3.7 & 5.1 & 5.7 \\
\hline Scholarships & 2.6 & 3.0 & 3.8 & 5.3 & 6.0 \\
\hline ISAE, IRST, primary school, other $1 /$ & 0.5 & 0.6 & 0.8 & 1.1 & 1.2 \\
\hline Health & 3.3 & 4.3 & 5.2 & 6.7 & 5.2 \\
\hline Wages and salaries & 1.4 & 1.5 & 1.6 & 1.8 & 1.5 \\
\hline Goods and services & 1.8 & 2.6 & 3.1 & 4.2 & 2.9 \\
\hline Transfers & 0.1 & 0.2 & 0.5 & 0.7 & 0.7 \\
\hline Social affairs/gender, women, and development & 20.4 & 22.7 & 26.3 & 32.5 & 37.8 \\
\hline Wages and salaries & 11.3 & 12.7 & 13.5 & 14.9 & 16.1 \\
\hline Goods and services & 2.8 & 3.5 & 4.5 & 6.2 & 8.8 \\
\hline Transfers & 6.3 & 6.5 & 8.3 & 11.4 & 12.8 \\
\hline Youth, culture, and sports & 1.4 & 1.5 & 8.6 & 11.2 & 16.0 \\
\hline Wages and salaries & 0.4 & 0.3 & 2.3 & 2.6 & 4.6 \\
\hline Goods and services & 0.5 & 1.1 & 4.7 & 6.4 & 9.0 \\
\hline Transfers & 0.5 & 0.1 & 1.6 & 2.2 & 2.4 \\
\hline
\end{tabular}

Sources: Rwandese authorities; and Fund staff estimates.

1/ ISAE and IRST are agricultural and technical research institutions; "other" includes higher-education activities. 
Table 15. Rwanda: Government Domestic Debt by Creditor, 1999-2004 (In millions of Rwanda francs)

\begin{tabular}{|c|c|c|c|c|c|c|}
\hline & 1999 & 2000 & 2001 & 2002 & 2003 & $\begin{array}{r}2004 \\
\text { Jun. }\end{array}$ \\
\hline Banking sector & $58,218.7$ & $55,291.9$ & $53,469.3$ & $57,826.0$ & $58,419.4$ & $52,786.2$ \\
\hline Central bank & $50,710.6$ & $44,618.2$ & $43,469.2$ & $42,911.8$ & $43,916.8$ & $42,125.7$ \\
\hline Consolidated debt $1 /$ & $43,469.2$ & $43,469.2$ & $43,469.2$ & $42,911.8$ & $42,427.9$ & $42,125.7$ \\
\hline Commercial banks & $7,508.1$ & $10,673.7$ & $10,000.1$ & $14,914.2$ & $14,502.6$ & $10,660.5$ \\
\hline Of which: treasury bills & $7,508.1$ & $10,673.7$ & $10,000.1$ & $14,914.2$ & $14,502.6$ & $10,660.5$ \\
\hline Nonbank financial institutions & $29,074.9$ & $27,184.9$ & $26,752.1$ & $28,786.9$ & $32,578.2$ & $39,711.9$ \\
\hline Treasury bills & $3,424.1$ & $3,179.6$ & $2,915.4$ & $6,534.5$ & $10,325.8$ & $17,459.5$ \\
\hline Of which: CSR & 669.8 & 669.8 & 669.8 & $1,900.0$ & 150.0 & $2,100.0$ \\
\hline Development bonds & $25,650.9$ & $24,005.4$ & $23,836.7$ & $22,252.4$ & $22,252.4$ & $22,252.4$ \\
\hline Of which: CSR & $24,135.4$ & $23,335.4$ & $22,535.4$ & $21,735.4$ & $21,735.4$ & $21,735.4$ \\
\hline Total domestic debt & $87,293.6$ & $82,476.8$ & $80,221.4$ & $86,612.9$ & $90,997.6$ & $92,498.1$ \\
\hline \multicolumn{7}{|c|}{ Memorandum items: } \\
\hline \multirow{2}{*}{\multicolumn{7}{|c|}{ Penalty interest on government }} \\
\hline & $\ldots$ & $\ldots$ & $\ldots$ & $\ldots$ & $\ldots$ & $\ldots$ \\
\hline
\end{tabular}

Sources: Ministry of Finance and Economic Planning; and the National Bank of Rwanda.

1/ Excludes RF 9.0 billion in central bank claims on government arising from exchange losses related to the exchange system in March 1995, as well as a RF 2.0 billion overdraft to the prewar government. 
Nonfinancial enterprises

Bugarama rice mill

Butare rice mill

BRALIRWA (brewery) 2/

Cimenterie du Rwanda (CIMERWA)

Compagnie Rwandaise d'Hôtellerie de Tourisme (CRHT)

Couvoir National de Rubirizi

ELECTROGAZ (electricity, water, and gas)

Gishwati dairy plant

Laiterie de Nyabishindu

Magasins Généraux du Rwanda (MAGERWA) 2/

Office des Cultures Industrielles du Rwanda - Café (OCIR-Cafe)

Office des Cultures Industrielles du Rwanda - Thé (OCIR-Thé) 3/

Office National des Transports en Commun (ONATRACOM)

Office Rwandais du Tourisme et des Parcs Nationaux (ORTPN)

Office de Valorisation Pastorale du Mutara (OVAPAM)

Office National des Postes

Papeterie du Rwanda

Prime Holdings (hotels)

REDEMI (mining)

Rwandair Express

Rwanda Télécommunications (Rwandatel)

Rwamagana rice mill

Régie des Aéroports du Rwanda (RAR)

Riziculture

Rwandair Express

RWANDEX (coffee)

RWANTEXCO (textiles)

Société des Transports Internationaux du Rwanda (STIR)

Société pour la Production Rizicole (SOPRORIZ)

SOPAB (animal food)

SOPROTEL (hotel)

SORWATHE (tea) 2/

TRAFIPRO (marketing of food products)

Financial institutions

Banque Nationale du Rwanda

Banque Commerciale du Rwanda (BCR)

Banque Continentale Africaine du Rwanda (BACAR)

Banque de Kigali (BK) 4/

Banque Rwandaise de Développement (BRD)

Caisse Hypothécaire du Rwanda

Société Nationale d'Assurance du Rwanda (SONARWA)

UBPR

Source: Ministry of Finance and Economic Planning.

Note: The above list excludes public entities (établissements publics) that serve social purposes (e.g., universities, research institutes, museums, the information office, and the population office). It includes enterprises that have private as well as public shareholders.

$1 /$ As of December 2003

2/ The government has a minority interest.

$3 /$ Includes nine tea factories.

4/ The government holds 50 percent. 
Table 17. Rwanda: Monetary Survey, 1999-2004 1/

\begin{tabular}{|c|c|c|c|c|c|c|c|c|c|c|}
\hline & \multirow[t]{2}{*}{1999} & \multirow[t]{2}{*}{2000} & \multirow[t]{2}{*}{2001} & \multirow[t]{2}{*}{2002} & \multicolumn{4}{|c|}{2003} & \multicolumn{2}{|c|}{2004} \\
\hline & & & & & Mar. & Jun. & Sep. & Dec. & Mar. & Jun. \\
\hline \multicolumn{11}{|l|}{ Monetary authorities } \\
\hline Net foreign assets & 27.0 & 37.4 & 51.3 & 72.6 & 71.1 & 70.6 & 58.9 & 65.5 & 67.0 & 70.2 \\
\hline Foreign liabilities & 33.9 & 44.7 & 45.8 & 52.1 & 53.1 & 57.2 & 55.2 & 58.8 & 57.9 & 56.7 \\
\hline Net domestic assets & 13.4 & 0.3 & -11.1 & -27.6 & -24.6 & -24.1 & -8.8 & -15.1 & -15.7 & -17.1 \\
\hline Domestic credit & 31.7 & 23.2 & 12.8 & -2.6 & -0.6 & 2.2 & 17.5 & 15.6 & 9.7 & 8.6 \\
\hline Government (net) 2/ & 30.4 & 20.1 & 16.0 & -5.2 & 1.9 & 3.5 & 15.3 & 12.7 & 11.0 & 7.3 \\
\hline Claims & 50.7 & 43.5 & 43.5 & 43.1 & 42.4 & 42.4 & 51.2 & 43.9 & 44.4 & 42.1 \\
\hline Deposits & 20.3 & 23.4 & 27.5 & 48.2 & 40.5 & 38.9 & 35.9 & 31.2 & 33.5 & 34.8 \\
\hline Treasury (including & 0.0 & 1.5 & 2.2 & 4.8 & 2.0 & 2.4 & 0.0 & 0.0 & 0.0 & 0.6 \\
\hline Line ministries & 20.3 & 21.9 & 25.3 & 43.4 & 38.5 & 36.5 & 35.9 & 31.2 & 33.5 & 34.3 \\
\hline Nongovernment credit & 3.0 & 4.2 & -1.9 & 3.5 & -1.6 & -0.3 & 3.1 & 3.9 & -0.3 & 2.3 \\
\hline Private sector & 1.0 & 1.4 & 1.9 & 2.2 & 2.2 & 2.3 & 2.3 & 2.4 & 2.5 & 3.0 \\
\hline Public enterprises & 0.2 & 0.1 & 0.1 & 0.1 & 0.1 & 0.1 & 0.1 & 0.1 & 0.1 & 0.1 \\
\hline Commercial banks & 1.8 & 2.6 & -3.9 & 1.2 & -3.9 & -2.7 & 0.7 & 1.4 & -3.0 & -0.9 \\
\hline Of which: money market & 0.0 & 0.8 & -5.4 & -0.1 & -5.1 & -4.0 & -0.7 & 0.0 & -4.6 & -2.4 \\
\hline Other items, net (asset: + ) & -18.3 & -22.9 & -24.0 & -25.0 & -24.0 & -26.4 & -26.3 & -30.7 & -25.3 & -25.7 \\
\hline Reserve money & 40.4 & 37.7 & 40.2 & 44.9 & 46.5 & 46.5 & 50.1 & 50.4 & 51.3 & 53.0 \\
\hline Currency in circulation & 21.5 & 22.6 & 25.8 & 28.0 & 26.4 & 29.4 & 32.1 & 34.1 & 31.9 & 37.5 \\
\hline Commercial bank reserves 3 / & 16.8 & 12.3 & 10.7 & 13.2 & 15.5 & 12.9 & 14.9 & 13.4 & 15.4 & 13.2 \\
\hline Other nonbank deposits & 2.0 & 2.8 & 3.7 & 3.7 & 4.6 & 4.3 & 3.2 & 3.0 & 4.0 & 2.4 \\
\hline $\begin{array}{l}\text { Of which: Caisse Sociale du Rwanda, } \\
\text { and other autonomous public agenci }\end{array}$ & 0.5 & 1.5 & 1.1 & 1.0 & 13 & 0.7 & 0.4 & 0.7 & 0.7 & 0.2 \\
\hline \multicolumn{11}{|l|}{ Commercial banks } \\
\hline Net foreign assets & 17.9 & 29.5 & 29.7 & 31.2 & 33.2 & 33.3 & 31.7 & 38.7 & 36.7 & 39.0 \\
\hline Foreign assets & 19.8 & 32.9 & 34.3 & 39.1 & 40.1 & 44.9 & 42.3 & 49.8 & 50.1 & 51.9 \\
\hline Foreign liabilities & 1.9 & 3.5 & 4.6 & 8.0 & 6.9 & 11.7 & 10.5 & 11.1 & 13.4 & 12.9 \\
\hline Reserves & 16.8 & 12.3 & 10.7 & 13.2 & 15.5 & 12.9 & 14.9 & 13.4 & 15.4 & 13.2 \\
\hline NBR deposits & 14.3 & 10.3 & 7.9 & 10.5 & 11.0 & 8.3 & 11.6 & 11.0 & 11.9 & 10.6 \\
\hline Required reserves & 8.5 & 7.3 & 8.4 & 9.7 & 10.2 & 10.8 & 11.4 & 11.9 & 11.8 & 11.5 \\
\hline Excess reserves & 5.9 & 2.9 & -0.5 & 0.8 & 0.8 & -2.4 & 0.1 & -0.9 & 0.0 & -0.9 \\
\hline NBR borrowing from money market & 0.0 & 0.0 & 5.4 & 1.1 & 5.1 & 4.0 & 0.7 & 0.0 & 4.6 & 2.4 \\
\hline Cash in vault & 2.5 & 2.0 & 2.8 & 2.7 & 4.4 & 4.5 & 3.3 & 2.4 & 3.5 & 2.6 \\
\hline Credit from NBR (rediscount; liability -) & -1.8 & -2.6 & 3.9 & -1.2 & 3.9 & 2.7 & -0.7 & -1.4 & 3.0 & 0.9 \\
\hline Domestic credit & 64.2 & 74.3 & 78.4 & 93.7 & 85.2 & 91.6 & 103.8 & 104.4 & 96.6 & 98.6 \\
\hline Central government (net) & 3.7 & 4.1 & 2.1 & 7.1 & 3.6 & 2.5 & 5.7 & 4.8 & -2.7 & -1.2 \\
\hline Credit & 7.7 & 7.3 & 8.2 & 14.7 & 13.9 & 20.5 & 16.6 & 15.2 & 10.4 & 11.5 \\
\hline Deposits & 4.0 & 3.1 & 6.1 & 7.6 & 10.3 & 18.0 & 10.9 & 10.4 & 13.1 & 12.7 \\
\hline Public enterprises & 0.7 & 0.7 & 0.8 & 3.4 & 2.3 & 3.2 & 4.6 & 4.8 & 4.0 & 5.0 \\
\hline Private sector & 59.7 & 69.4 & 75.5 & 83.3 & 79.3 & 85.8 & 93.4 & 94.8 & 95.4 & 94.8 \\
\hline Other items, net (assets: + ) & -16.3 & -19.5 & -21.9 & -23.6 & -25.2 & -27.8 & -26.6 & -25.0 & -24.8 & -30.1 \\
\hline Deposits & 80.8 & 93.8 & 100.7 & 113.3 & 112.6 & 112.7 & 123.1 & 130.0 & 126.9 & 121.6 \\
\hline Private & 68.5 & 80.3 & 85.5 & 97.9 & 96.6 & 97.6 & 102.1 & 110.1 & 105.1 & 103.0 \\
\hline Public (nongovernment) & 12.3 & 13.6 & 15.2 & 15.4 & 16.0 & 15.1 & 21.0 & 19.9 & 21.9 & 18.6 \\
\hline Monetary survey & & & & & & & & & & \\
\hline Net foreign assets & 44.9 & 66.9 & 81.0 & 103.7 & 104.3 & 103.8 & 90.6 & 104.2 & 103.7 & 109.2 \\
\hline Net domestic assets & 59.4 & 52.4 & 49.3 & 41.3 & 39.4 & 42.5 & 67.7 & 62.9 & 59.2 & 52.2 \\
\hline Domestic credit & 94.0 & 94.8 & 95.1 & 90.0 & 88.6 & 96.6 & 120.5 & 118.6 & 109.3 & 108.1 \\
\hline Central government (net) & 34.2 & 24.2 & 18.1 & 1.9 & 5.5 & 6.0 & 21.0 & 17.5 & 8.2 & 6.1 \\
\hline $\begin{array}{l}\text { Public enterprises } \\
\text { Pits }\end{array}$ & 0.9 & 0.8 & 1.0 & 3.5 & 2.4 & 3.3 & 4.8 & 4.9 & 4.1 & 5.1 \\
\hline Private sector & 60.7 & 70.9 & 77.4 & 85.5 & 81.5 & 88.1 & 95.7 & 97.2 & 97.9 & 97.8 \\
\hline Other items, net (assets: + ) & -34.6 & -42.4 & -45.9 & -48.6 & -49.2 & -54.1 & -52.9 & -55.7 & -50.1 & -55.8 \\
\hline Broad money & 104.3 & 119.2 & 130.2 & 145.1 & 143.7 & 146.3 & 158.3 & 167.1 & 162.9 & 161.4 \\
\hline Currency in circulation & 21.5 & 22.6 & 25.8 & 28.0 & 26.4 & 29.4 & 32.1 & 34.1 & 31.9 & 37.5 \\
\hline Deposits & 82.8 & 96.7 & 104.4 & 117.0 & 117.2 & 116.9 & 126.2 & 133.0 & 131.0 & 124.0 \\
\hline Of which: foreign currency deposits & 19.5 & 26.7 & 27.9 & 29.4 & 30.3 & 36.0 & 38.0 & 41.5 & 37.9 & 35.9 \\
\hline Net foreign assets & -3.4 & 21.1 & 11.8 & 17.5 & 27.3 & 24.5 & 12.9 & 0.3 & -0.4 & 3.7 \\
\hline Net domestic asset & 10.0 & -6.8 & -2.6 & -6.1 & -15.4 & -15.2 & 6.0 & 14.8 & 13.8 & 6.7 \\
\hline Domestic credit & 12.8 & 0.7 & 0.3 & -4.0 & -8.1 & -4.2 & 13.7 & 19.7 & 14.4 & 7.9 \\
\hline Government (net) & 8.0 & -9.6 & -5.1 & -12.4 & -13.1 & -11.4 & 0.7 & 10.7 & 1.9 & 0.1 \\
\hline Economy & 4.8 & 10.3 & 5.4 & 8.5 & 5.0 & 7.2 & 13.0 & 9.0 & 12.5 & 7.8 \\
\hline Other items, net & -2.8 & -7.5 & -2.9 & -2.1 & -7.2 & -11.1 & -7.7 & -4.9 & -0.6 & -1.2 \\
\hline Broad money & 6.5 & 14.3 & 9.2 & 11.4 & 11.9 & 9.2 & 19.0 & 15.2 & 13.4 & 10.4 \\
\hline Memorandum items: & & & & & & & & & & \\
\hline Currency/broad money ratio & 20.6 & 18.9 & 19.8 & 19.3 & 18.4 & 20.1 & 20.3 & 20.4 & 19.6 & 23.2 \\
\hline Reserve money annual growth & 13.3 & -6.6 & 6.6 & 11.9 & 5.8 & 12.5 & 26.0 & 12.2 & 10.4 & 14.1 \\
\hline Reserves/deposits & 50.0 & 40.2 & 39.9 & 39.7 & 41.3 & 41.3 & 40.7 & 38.8 & 40.4 & 43.6 \\
\hline Money multiplier & 2.6 & 3.2 & 3.2 & 3.2 & 3.1 & 3.1 & 3.2 & 3.3 & 3.2 & 3.0 \\
\hline Velocity (GDP/M2; end of period) & 6.2 & 5.9 & 5.8 & 5.7 & $\ldots$ & $\ldots$ & $\ldots$ & 5.4 & $\ldots$ & $\ldots$ \\
\hline Velocity (GDP/M2; avg.) & 6.3 & 6.5 & 6.0 & 6.5 & $\ldots$ & $\ldots$ & $\ldots$ & 7.0 & $\ldots$ & $\ldots$ \\
\hline Nominal GDP (in billions of Rwanda fra & 644.9 & 705.7 & 754.3 & 825.0 & $\ldots$ & $\ldots$ & $\ldots$ & 905.3 & $\ldots$ & $\ldots$ \\
\hline
\end{tabular}

Source: National Bank of Rwanda (NBR)

1/ Actual figures are based on current exchange rates and are not adjusted for program adjustments, as described in the technical memorandum of understanding.

2/ Net credit to government

3/ The reserve requirement was reduced in July 1998 from 12 percent to 10 percent. 
Table 18. Rwanda: Summary Accounts of the National Bank of Rwanda, 1999-2004

(In billions of Rwanda francs; end of period)

\begin{tabular}{|c|c|c|c|c|c|c|c|c|c|c|}
\hline & \multirow[t]{2}{*}{1999} & \multirow[t]{2}{*}{2000} & \multirow[t]{2}{*}{2001} & \multirow[t]{2}{*}{2002} & \multicolumn{4}{|c|}{2003} & \multicolumn{2}{|c|}{2004} \\
\hline & & & & & Mar. & Jun. & Sep. & Dec. & Mar. & Jun. \\
\hline Foreign assets & 60.9 & 82.1 & 97.1 & 124.7 & 124.1 & 127.7 & 114.0 & 124.5 & 124.9 & 126.8 \\
\hline SDR holdings & $\ldots$ & $\ldots$ & 5.6 & 5.2 & 15.0 & 16.0 & 16.7 & 17.0 & 17.1 & 16.9 \\
\hline Claims on government & 50.7 & 43.5 & 43.5 & 42.9 & 42.4 & 42.4 & 51.2 & 43.9 & 44.4 & 42.1 \\
\hline Ordinary advances & 7.2 & 0.0 & 0.0 & 0.0 & 0.0 & 0.0 & 8.8 & 1.5 & 2.3 & 0.0 \\
\hline Special advances & 0.0 & 0.0 & 0.0 & 0.0 & 0.0 & 0.0 & 0.0 & 0.0 & 0.0 & 0.0 \\
\hline Consolidated debt & 43.5 & 43.5 & 43.5 & 42.9 & 42.4 & 42.4 & 42.4 & 42.4 & 42.1 & 42.1 \\
\hline Postal checking system & 0.0 & 0.0 & 0.0 & 0.0 & 0.0 & 0.0 & 0.0 & 0.0 & 0.0 & 0.0 \\
\hline Other & 0.0 & 0.0 & 0.0 & 0.0 & 0.0 & 0.0 & 0.0 & 0.0 & 0.0 & 0.0 \\
\hline Claims on public enterprises & 0.2 & 0.1 & 0.1 & 0.1 & 0.1 & 0.1 & 0.1 & 0.1 & 0.1 & 0.1 \\
\hline Claims on the private sector & 0.6 & 1.1 & 1.7 & 2.1 & 2.1 & 2.2 & 2.2 & 2.3 & 2.4 & 2.6 \\
\hline Claims on deposit money banks & 1.8 & 1.8 & 1.5 & 1.2 & 1.2 & 1.3 & 1.4 & 1.4 & 1.6 & 1.5 \\
\hline Money market loans & 0.0 & 0.8 & 0.0 & 1.0 & 0.0 & 0.0 & 0.0 & 0.0 & 0.0 & 0.0 \\
\hline Claims on other financial institutions & 0.4 & 0.3 & 0.2 & 0.1 & 0.1 & 0.1 & 0.1 & 0.1 & 0.1 & 0.4 \\
\hline Unclassified assets & 43.1 & 53.1 & 56.4 & 60.6 & 62.4 & 66.9 & 71.1 & 76.7 & 79.2 & 81.3 \\
\hline Total assets & 157.7 & 182.8 & 200.5 & 232.7 & 232.5 & 240.7 & 240.2 & 249.0 & 252.8 & 254.9 \\
\hline Reserve money 1/ & 40.4 & 37.8 & 40.2 & 44.9 & 46.7 & 46.5 & 50.1 & 50.4 & 51.3 & 53.0 \\
\hline Currency outside banks & 21.5 & 22.6 & 25.8 & 28.0 & 26.5 & 29.4 & 32.1 & 34.1 & 31.9 & 36.9 \\
\hline Out of : total currency & 24.0 & 24.6 & 28.6 & 30.7 & 30.9 & 33.9 & 35.4 & 36.5 & 35.4 & 40.0 \\
\hline Currency in commercial banks & 2.5 & 2.0 & 2.8 & 2.7 & 4.4 & 4.5 & 3.3 & 2.4 & 3.5 & 3.2 \\
\hline Bank deposits & 14.3 & 10.3 & 7.9 & 10.5 & 11.0 & 8.3 & 11.6 & 11.0 & 11.9 & 10.6 \\
\hline Money market deposits & 0.0 & 0.0 & 6.5 & 1.1 & 5.3 & 4.0 & 0.7 & 0.0 & 4.6 & 2.4 \\
\hline Commercial banks & 0.0 & 0.0 & 6.5 & 1.1 & 5.1 & 4.0 & 0.7 & 0.0 & 4.6 & 2.4 \\
\hline Nonbanks & 0.0 & 0.0 & 0.0 & 0.0 & 0.2 & 0.0 & 0.0 & 0.0 & 0.0 & 0.0 \\
\hline Other deposits & 0.7 & 0.9 & 0.8 & 0.4 & 0.4 & 0.3 & 0.3 & 0.4 & 0.4 & 1.8 \\
\hline Private sector deposits & 0.0 & 0.0 & 0.2 & 0.0 & 0.0 & 0.0 & 0.0 & 0.0 & 0.1 & 0.0 \\
\hline Public enterprises & 0.6 & 0.4 & 0.3 & 0.3 & 0.4 & 0.2 & 0.3 & 0.3 & 0.3 & 0.3 \\
\hline Caisse Sociale du Rwanda and other agencies & 0.5 & 1.6 & 1.3 & 1.8 & 2.8 & 2.3 & 1.4 & 1.6 & 2.5 & 0.8 \\
\hline Coffee funds & 0.0 & 0.0 & 0.0 & 0.0 & 0.0 & 0.0 & 0.0 & 0.0 & 0.0 & 0.0 \\
\hline Public institutions & 0.4 & 0.5 & 0.9 & 1.0 & 0.7 & 0.6 & 0.3 & 0.7 & 0.7 & 0.5 \\
\hline Community deposits & 0.1 & 0.1 & 0.2 & 0.0 & 0.1 & 0.3 & 0.1 & 0.4 & 0.5 & 0.2 \\
\hline Social security fund+RAMA & 0.1 & 1.0 & 0.2 & 0.1 & 0.8 & 0.2 & 0.4 & 0.1 & 0.3 & 0.0 \\
\hline Other financial institutions' deposits & 0.1 & 0.6 & 0.3 & 0.6 & 1.1 & 1.2 & 0.5 & 0.4 & 0.9 & 0.1 \\
\hline More deposits & 0.9 & 0.4 & 1.6 & 1.7 & 1.6 & 2.0 & 1.6 & 1.4 & 2.1 & 1.8 \\
\hline Import deposits & 0.1 & 0.1 & 0.1 & 0.3 & 0.3 & 0.7 & 0.3 & 0.1 & 0.5 & 0.3 \\
\hline Other & 0.8 & 0.4 & 1.6 & 1.4 & 1.3 & 1.3 & 1.3 & 1.3 & 1.6 & 1.4 \\
\hline Foreign liabilities & 33.9 & 44.7 & 45.8 & 52.1 & 53.1 & 57.2 & 55.2 & 58.9 & 57.9 & 56.7 \\
\hline Of which: Structural Adjustment Facility & 1.3 & 0.5 & 0.0 & 1.3 & 1.3 & 0.9 & 0.9 & 0.5 & 0.0 & 0.0 \\
\hline Enhanced Structural Adjustment & & & & & & & & & & \\
\hline Facility & 16.0 & 29.4 & 35.4 & 43.0 & 43.5 & 46.8 & 49.3 & 52.5 & 52.6 & 53.6 \\
\hline Project import fund & 0.0 & 0.0 & 0.0 & 0.0 & 0.0 & 0.0 & 0.0 & 0.0 & 0.0 & 0.0 \\
\hline Government deposits & 22.0 & 24.4 & 28.6 & 49.1 & 41.3 & 39.6 & 36.7 & 31.8 & 33.9 & 35.6 \\
\hline OTR (Central Treasury Account) & 0.0 & 1.5 & 2.2 & 4.8 & 2.0 & 2.4 & 0.0 & 0.0 & 0.0 & 0.6 \\
\hline Rwanda Revenue Authority & 0.9 & 0.7 & 0.4 & 0.9 & 0.5 & 0.4 & 0.7 & 0.8 & 0.7 & 0.7 \\
\hline Other (including projects) & 19.5 & 20.9 & 25.2 & 42.8 & 37.9 & 36.0 & 35.4 & 30.4 & 32.5 & 33.5 \\
\hline Counterpart funds & 1.6 & 1.3 & 0.8 & 0.6 & 0.8 & 0.7 & 0.6 & 0.7 & 0.7 & 0.8 \\
\hline Long-term liabilities (Trust Fund Loans) & 0.0 & 0.0 & 0.0 & 0.0 & 0.0 & 0.0 & 0.0 & 0.0 & 0.0 & 0.0 \\
\hline Capital, reserves, and SDR allocations & 15.6 & 15.4 & 18.1 & 23.1 & 21.6 & 22.2 & 22.7 & 29.0 & 28.0 & 28.0 \\
\hline Unclassified liabilities & 45.7 & 60.6 & 61.3 & 62.5 & 64.6 & 71.1 & 74.7 & 78.5 & 76.6 & 79.0 \\
\hline Total liabilities & 157.7 & 182.8 & 200.5 & 232.9 & 232.5 & 240.7 & 240.2 & 249.0 & 252.8 & 254.9 \\
\hline
\end{tabular}

Source: National Bank of Rwanda (NBR).

1/ Reserve money excludes money market deposits of commercial banks.

CInternational Monetary Fund. Not for Redistribution 
Table 19. Rwanda: Summary Accounts of Commercial Banks, 1999-2003 (In billions of Rwanda francs)

\begin{tabular}{|c|c|c|c|c|c|c|c|c|}
\hline & \multirow[t]{2}{*}{1999} & \multirow[t]{2}{*}{2000} & \multirow[t]{2}{*}{2001} & \multirow[t]{2}{*}{2002} & \multicolumn{4}{|c|}{2003} \\
\hline & & & & & Mar. & Jun. & Sep. & Dec. \\
\hline Reserves & 16.8 & 12.3 & 17.1 & 14.3 & 20.5 & 16.8 & 15.6 & 13.4 \\
\hline Cash & 2.5 & 2.0 & 2.8 & 2.7 & 4.4 & 4.5 & 3.3 & 2.4 \\
\hline Deposits at the NBR & 14.3 & 10.3 & 7.9 & 10.5 & 11.0 & 8.3 & 11.6 & 11.0 \\
\hline Money market loans & 0.0 & 0.0 & 6.5 & 1.1 & 5.1 & 4.0 & 0.7 & 0.0 \\
\hline Foreign assets & 19.8 & 32.9 & 34.3 & 39.1 & 38.8 & 44.9 & 42.3 & 49.8 \\
\hline Claims on government & 7.7 & 7.3 & 8.0 & 14.7 & 13.9 & 19.7 & 16.6 & 15.1 \\
\hline Claims on nongovernment sector & 77.2 & 85.1 & 93.1 & 107.3 & 102.3 & 113.1 & 122.8 & 124.1 \\
\hline Claims on public enterprises & 0.7 & 0.7 & 0.8 & 3.4 & 2.3 & 3.2 & 4.7 & 4.8 \\
\hline Claims on private sector & 59.6 & 69.3 & 75.3 & 83.2 & 79.1 & 85.0 & 93.2 & 95.2 \\
\hline Claims on other financial institutions & 0.2 & 0.1 & 0.2 & 0.1 & 0.2 & 0.8 & 0.2 & 0.2 \\
\hline Other & 16.7 & 15.0 & 16.8 & 20.6 & 20.7 & 24.1 & 24.7 & 23.9 \\
\hline Total assets & 121.5 & 137.7 & 152.5 & 175.4 & 175.5 & 194.5 & 197.2 & 202.4 \\
\hline Total deposits & 87.5 & 97.8 & 106.5 & 123.2 & 126.4 & 134.1 & 136.4 & 141.9 \\
\hline Nongovernment sector deposits & 75.1 & 87.5 & 99.8 & 111.4 & 112.3 & 111.1 & 122.0 & 128.8 \\
\hline Demand deposits & 36.3 & 36.8 & 38.4 & 43.4 & 43.9 & 46.2 & 49.3 & 49.4 \\
\hline Of which: other financial institutions & 0.8 & 0.6 & 0.0 & 3.2 & 1.8 & 3.0 & 3.0 & 3.2 \\
\hline Time and saving deposits & 19.3 & 24.1 & 33.6 & 39.5 & 38.2 & 29.3 & 35.6 & 38.1 \\
\hline Of which: other financial institutions & 2.9 & 4.6 & 0.0 & 13.1 & 13.2 & 5.1 & 11.1 & 10.1 \\
\hline Foreign currency deposits & 19.5 & 26.7 & 27.9 & 28.5 & 30.2 & 35.6 & 37.2 & 41.3 \\
\hline Of which: other financial institutions & 0.0 & 0.0 & 0.0 & 1.3 & 1.1 & 1.5 & 1.6 & 1.2 \\
\hline Deposits by other banks & 2.7 & 0.8 & 0.8 & 3.5 & 3.3 & 4.6 & 3.5 & 2.6 \\
\hline Government deposits & 9.7 & 9.4 & 5.9 & 8.4 & 10.9 & 18.4 & 10.9 & 10.5 \\
\hline Foreign liabilities & 1.9 & 3.5 & 4.6 & 8.0 & 6.9 & 11.7 & 10.5 & 11.1 \\
\hline Credits from the NBR & 1.6 & 2.4 & 1.4 & 2.2 & 1.2 & 1.3 & 1.4 & 1.4 \\
\hline Own capital & 19.9 & 23.4 & 26.2 & 23.8 & 22.8 & 24.4 & 26.9 & 27.9 \\
\hline Provisions and Guarantee Fund & 4.0 & 1.3 & 1.9 & 1.5 & 1.1 & 1.1 & 1.6 & 2.6 \\
\hline Reserves & 3.7 & 2.5 & 2.7 & 2.8 & 2.9 & 3.1 & 3.1 & 3.1 \\
\hline Capital & 2.9 & 7.5 & 9.1 & 9.6 & 9.6 & 9.6 & 10.8 & 10.6 \\
\hline Specific provisions & 8.6 & 11.7 & 12.7 & 21.1 & 21.2 & 21.1 & 21.4 & 21.6 \\
\hline Net profit & 0.6 & 0.3 & -0.2 & -11.2 & -12.0 & -10.5 & -9.9 & -9.9 \\
\hline Other liabilities & 10.7 & 10.7 & 13.8 & 18.2 & 18.2 & 23.0 & 21.9 & 20.1 \\
\hline Total liabilities & 121.5 & 137.7 & 152.5 & 175.4 & 175.5 & 194.5 & 197.2 & 202.4 \\
\hline
\end{tabular}

Source: National Bank of Rwanda (NBR). 
Table 20. Rwanda: Commercial Bank Credit, 1999-2004 ${ }^{1 /}$

(In millions of Rwanda francs)

\begin{tabular}{|c|c|c|c|c|c|c|}
\hline & 1999 & 2000 & 2001 & 2002 & 2003 & 2004 \\
\hline & & & & & & Mar. \\
\hline Total & 66,606 & 71,553 & 81,714 & 89,347 & 101,901 & 105,019 \\
\hline Agriculture & 876 & 967 & 1,065 & 1,410 & 2,381 & 2,262 \\
\hline Mining & 38 & 23 & 13 & 29 & 74 & 76 \\
\hline Manufacturing & 10,660 & 12,190 & 13,311 & 12,099 & 14,419 & 15,691 \\
\hline Construction & 1,301 & 1,791 & 1,891 & 2,056 & 1,929 & 2,503 \\
\hline Real estate, including Housing & 11,136 & 12,409 & 13,368 & 16,100 & 18,822 & 19,865 \\
\hline Distribution and tourism & 30,432 & 30,593 & 36,703 & 36,176 & 43,444 & 44,768 \\
\hline Transport and communications & 4,027 & 4,322 & 5,674 & 8,217 & 9,478 & 8,466 \\
\hline Other & 8,136 & 9,258 & 9,689 & 13,260 & 11,354 & 11,388 \\
\hline Short term (< one year) & 40,681 & 44,675 & 51,157 & 54,937 & 54,762 & 54,400 \\
\hline Agriculture & 133 & 339 & 249 & 158 & 499 & 197 \\
\hline Mining & 0 & 0 & 0 & 0 & 0 & 0 \\
\hline Manufacturing & 5,380 & 7,217 & 7,805 & 5,831 & 6,046 & 7,014 \\
\hline Construction & 1,224 & 1,723 & 1,794 & 1,960 & 1,733 & 2,337 \\
\hline Real estate, including Housing & 1,599 & 1,242 & 1,523 & 3,071 & 2,941 & 2,320 \\
\hline Distribution and tourism & 25,662 & 25,596 & 30,656 & 30,359 & 33,026 & 33,324 \\
\hline Transport and communications & 644 & 1,329 & 1,774 & 3,243 & 3,812 & 2,681 \\
\hline Other & 6,039 & 7,229 & 7,356 & 10,315 & 6,705 & 6,527 \\
\hline Medium term (one to five years) & 16,613 & 15,373 & 17,959 & 17,186 & 26,607 & 29,664 \\
\hline Agriculture & 233 & 259 & 255 & 450 & 1,021 & 1,176 \\
\hline Mining & 25 & 10 & 0 & 16 & 13 & 12 \\
\hline Manufacturing & 2,970 & 2,487 & 3,162 & 1,891 & 3,842 & 4,333 \\
\hline Construction & 58 & 49 & 78 & 77 & 177 & 147 \\
\hline Real estate, including Housing & 5,446 & 5,262 & 5,444 & 5,561 & 7,526 & 8,813 \\
\hline Distribution and tourism & 3,643 & 3,740 & 4,345 & 3,492 & 7,085 & 8,195 \\
\hline Transport and communications & 2,841 & 2,356 & 3,256 & 4,290 & 4,832 & 4,882 \\
\hline Other & 1,397 & 1,210 & 1,419 & 1,409 & 2,111 & 2,106 \\
\hline Long term (> five years) & 9,312 & 11,505 & 12,598 & 17,224 & 20,532 & 20,955 \\
\hline Agriculture & 510 & 369 & 561 & 802 & 861 & 889 \\
\hline Mining & 13 & 13 & 13 & 13 & 61 & 64 \\
\hline Manufacturing & 2,310 & 2,486 & 2,344 & 4,377 & 4,531 & 4,344 \\
\hline Construction & 19 & 19 & 19 & 19 & 19 & 19 \\
\hline Real estate, including Housing & 4,091 & 5,905 & 6,401 & 7,468 & 8,355 & 8,732 \\
\hline Distribution and tourism & 1,127 & 1,257 & 1,702 & 2,325 & 3,333 & 3,249 \\
\hline Transport and communications & 542 & 637 & 644 & 684 & 834 & 903 \\
\hline Other & 700 & 819 & 914 & 1,536 & 2,538 & 2,755 \\
\hline
\end{tabular}

Source: National Bank of Rwanda (NBR).

1/ including BRD, CHR \& Caisse centrale de l'UBPR 
Table 21. Rwanda : Financial Sector Indicators, 1999-2004

(In billions of Rwanda francs, unless otherwise indicated)

\begin{tabular}{|c|c|c|c|c|c|c|}
\hline & 1999 & 2000 & 2001 & 2002 & 2003 & $\begin{array}{l}2004 \\
\text { Mar. }\end{array}$ \\
\hline \multicolumn{7}{|l|}{ Commercials banks } \\
\hline Nonperfoming loans & 27.2 & 29.2 & 38.5 & 34.4 & 37.4 & 35.6 \\
\hline (in percent of private sector loans) & 37.5 & 36.1 & 37.9 & 41.0 & 33.9 & 29.5 \\
\hline Required provisioning & 16.8 & 17.9 & 22.5 & 21.2 & 21.9 & 22.7 \\
\hline Actual provisioning & 12.2 & 14.2 & 15.5 & 22.3 & 21.4 & 22.6 \\
\hline Required capital adequacy ratio (in percent) & 5.0 & 8.0 & 8.0 & 8.0 & 8.0 & 10.0 \\
\hline Actual capital adequacy ratio (in percent)/ & 6.2 & 8.0 & 3.4 & 0.5 & 3.0 & 2.3 \\
\hline Required foreign currency exposure limit & $\ldots$ & $\ldots$ & $\ldots$ & $\ldots$ & $\ldots$ & $\ldots$ \\
\hline Required reserve & $\ldots$ & $\ldots$ & $\ldots$ & $\cdots$ & $\cdots$ & $\cdots$ \\
\hline (in percent of total depositis) & 10.0 & 8.0 & 8.0 & 8.0 & 8.0 & 8.0 \\
\hline Actual reserves & $\ldots$ & $\ldots$ & $\ldots$ & $\ldots$ & $\ldots$ & $\cdots$ \\
\hline (in percent of total depositis) & 20.8 & 13.1 & 10.6 & 11.7 & 10.3 & 12.1 \\
\hline
\end{tabular}

Source: National Bank of Rwanda ( NBR ) 
Table 22. Rwanda: Interest Rates, 1999-2004

(In percent; end of period)

\begin{tabular}{|c|c|c|c|c|c|c|c|c|c|c|c|c|c|c|c|c|c|c|c|c|c|c|}
\hline & \multicolumn{4}{|c|}{1999} & \multicolumn{4}{|c|}{2000} & \multicolumn{4}{|c|}{2001} & \multicolumn{4}{|c|}{2002} & \multicolumn{4}{|c|}{2003} & \multicolumn{2}{|c|}{2004} \\
\hline & Mar. & Jun. & Sep. & $\overline{\text { Dec. }}$ & Mar. & Jun. & Sep. & $\overline{\text { Dec. }}$ & Mar. & Jun. & Sep. & $\overline{\text { Dec. }}$ & Mar. & Jun. & Sep. & $\overline{\text { Dec. }}$ & Mar. & Jun. & Sep. & $\overline{\text { Dec. }}$ & Mar. & Jun. \\
\hline Discount rate & 11.6 & 11.1 & 10.7 & 11.2 & 10.0 & 10.0 & 10.0 & 10.0 & 10.0 & 10.0 & 13.0 & 13.0 & 13.0 & 12.0 & 13.2 & 13.0 & 13.0 & 13.5 & 14.5 & 14.5 & 14.5 & 14.5 \\
\hline NBR money market borrowing rate $1 /$ & 7.5 & 7.1 & 7.7 & 8.2 & 8.9 & 9.1 & 9.3 & 9.9 & 9.9 & 7.8 & 7.6 & 9.5 & 8.4 & 7.5 & 9.8 & 10.5 & 10.2 & 9.3 & 11.0 & 11.6 & 11.9 & 11.4 \\
\hline \multicolumn{23}{|l|}{ Deposit rates } \\
\hline 1 month & 6.1 & 8.6 & 7.5 & 7.5 & 7.4 & 7.7 & 7.6 & 8.3 & 8.3 & 9.3 & 7.9 & 8.7 & 8.7 & 7.8 & 7.0 & 7.1 & 7.1 & 8.2 & 7.9 & 8.5 & 7.1 & $\ldots$ \\
\hline 3 months & 8.0 & 7.6 & 7.2 & 7.3 & 7.6 & 8.9 & 9.8 & 10.1 & 9.4 & 10.2 & 8.1 & 7.6 & 7.4 & 8.3 & 8.0 & 7.8 & 8.0 & 8.5 & 7.9 & 8.4 & 8.0 & $\ldots$ \\
\hline 6 months & 8.5 & 8.7 & 8.1 & 8.8 & 9.7 & 9.7 & 9.7 & 9.8 & 9.0 & 9.5 & 9.8 & 9.8 & 9.8 & 9.8 & 7.7 & 7.9 & 7.9 & 9.4 & 9.0 & 9.4 & 7.9 & $\ldots$ \\
\hline 12 months & 9.8 & 10.5 & 10.2 & 10.1 & 10.3 & 10.0 & 9.7 & 10.0 & 9.7 & 9.5 & 9.8 & 10.0 & 10.0 & 9.9 & 8.6 & 8.7 & 8.4 & 9.7 & 8.6 & 8.6 & 8.4 & \\
\hline \multicolumn{23}{|l|}{ Lending rates } \\
\hline Maximum & 18.0 & 18.0 & 18.0 & 18.0 & 18.0 & 18.0 & 18.0 & 17.9 & 17.7 & 17.2 & 22.0 & 21.2 & 22.0 & 19.0 & 18.0 & 18.0 & 19.0 & 18.0 & 18.0 & 19.5 & 19.5 & $\ldots$ \\
\hline Range/Minimum & 15.9 & 16.1 & 16.3 & 16.8 & 15.6 & 16.9 & 16.4 & 17.0 & 16.9 & 15.8 & 18.2 & 17.3 & 16.8 & 16.7 & 17.3 & 16.4 & 14.9 & 16.9 & 16.4 & 17.1 & 16.3 & $\ldots$ \\
\hline Interbank money market rate & 8.0 & 8.4 & 8.5 & 8.8 & 10.0 & 10.2 & 10.0 & 8.7 & 10.0 & 10.2 & 10.0 & 11.1 & 9.7 & 10.2 & 10.0 & 9.9 & 9.1 & 9.5 & 10.8 & 10.4 & 10.2 & 11.1 \\
\hline
\end{tabular}

Source: National Bank of Rwanda (NBR) 
Table 23. Rwanda: Balance of Payments, 1999-2003

(In millions of U.S. dollars)

\begin{tabular}{|c|c|c|c|c|c|}
\hline & 1999 & 2000 & 2001 & 2002 & 2003 \\
\hline $\begin{array}{l}\text { Exports, f.o.b. } \\
\text { Of which }\end{array}$ & 62.0 & 89.8 & 93.5 & 67.3 & 63.0 \\
\hline Tea & 17.5 & 24.3 & 22.7 & 22.0 & 22.5 \\
\hline Imports, f.o.b. & 248.8 & 239.8 & 237.9 & 234.7 & 244.0 \\
\hline Trade balance & -186.7 & -150.1 & -144.4 & -167.4 & -181.0 \\
\hline Services (net) & -143.0 & -141.4 & -125.3 & -125.1 & -143.4 \\
\hline Transfers (net) & 193.7 & 216.6 & 191.9 & 194.8 & 223.8 \\
\hline Private & 18.2 & 11.0 & 21.7 & 24.5 & 31.3 \\
\hline Public & 175.5 & 205.6 & 170.1 & 170.3 & 192.5 \\
\hline Current account balance (including official transfers) & -147.5 & -90.2 & -100.3 & -116.7 & -131.1 \\
\hline Current account balance (excluding official transfers) & -323.0 & -295.8 & -270.5 & -287.0 & -323.6 \\
\hline Capital tranfers & 70.1 & 71.8 & 63.4 & 41.6 & 41.1 \\
\hline Direct investment & 1.7 & 8.1 & 3.8 & 2.6 & 4.7 \\
\hline Long-term borrowing & 86.5 & 47.3 & 78.4 & 83.9 & 39.9 \\
\hline Scheduled amortization (-) & -34.7 & -26.4 & -19.4 & -29.4 & -28.0 \\
\hline Other & 10.4 & 3.7 & 19.1 & 9.5 & 9.3 \\
\hline Capital and financial account balance & 134.0 & 104.6 & 145.3 & 108.1 & 66.9 \\
\hline Errors and omissions & -3.7 & -18.1 & -20.6 & 27.9 & 27.3 \\
\hline Overall balance & -17.2 & -3.8 & 24.4 & 19.3 & -36.9 \\
\hline Financing & 17.2 & 3.8 & -24.4 & -19.2 & 36.9 \\
\hline Change in net foreign assets of NBR (increase -) & 10.1 & -9.8 & -25.1 & -29.7 & 28.8 \\
\hline Net credit from the Fund & 20.8 & 14.0 & 1.5 & -6.0 & -0.9 \\
\hline Change in gross official reserves (increase -) & -4.7 & -16.5 & -21.4 & -31.6 & 29.4 \\
\hline Change in other foreign liabilities (increase + ) & -6.0 & -7.3 & -5.3 & 7.9 & 0.3 \\
\hline Change in arrears (decrease -) & -2.7 & 7.1 & -37.8 & 4.6 & -22.6 \\
\hline Exceptional financing & 9.7 & 6.4 & 38.6 & 5.9 & 30.7 \\
\hline
\end{tabular}

Sources: National Bank of Rwanda (NBR); and Fund staff estimates. 
Table 24. Rwanda: Exports, 1999-2003

(In millions of U.S. dollars, unless otherwise indicated)

\begin{tabular}{|c|c|c|c|c|c|}
\hline & 1999 & 2000 & 2001 & 2002 & 2003 \\
\hline Total exports, f.o.b. & 62.0 & 89.8 & 93.5 & 67.3 & 63.0 \\
\hline Percent change & -3.3 & 44.7 & 4.2 & -28.1 & -6.3 \\
\hline \multicolumn{6}{|l|}{ Moving indices $(1992=100)$} \\
\hline Price index & 127.9 & 154.7 & 117.8 & 102.2 & 110.2 \\
\hline Percent change & -14.2 & 20.9 & -23.8 & -13.2 & 7.9 \\
\hline Volume index & 70.5 & 84.4 & 115.5 & 95.8 & 83.1 \\
\hline Percent change & 12.7 & 19.7 & 36.8 & -17.1 & -13.2 \\
\hline \multicolumn{6}{|l|}{ Fixed indices $(1992=100)$} \\
\hline Price index & 97.8 & 174.7 & 153.8 & 91.7 & 87.0 \\
\hline Percent change & -10.9 & 78.6 & -12.0 & -40.4 & -5.2 \\
\hline Volume index & 92.2 & 74.7 & 88.5 & 106.7 & 105.4 \\
\hline Percent change & 22.4 & -3.3 & 1930.1 & 17.7 & -18.4 \\
\hline \multicolumn{6}{|l|}{ By commodity } \\
\hline Coffee & 26.5 & 22.5 & 19.4 & 14.6 & 15.0 \\
\hline Percent change & -5.9 & -14.9 & -14.1 & -24.7 & 2.9 \\
\hline Volume ( 1,000 tons $)$ & 18.3 & 16.1 & 17.8 & 19.8 & 14.7 \\
\hline Percent change & 22.2 & -12.2 & 10.6 & 11.3 & -25.7 \\
\hline Unit value (cents per lb.) & 65.5 & 63.5 & 49.4 & 33.4 & 35.4 \\
\hline Unit value (U.S. dollars per kg.) & 1.4 & 1.4 & 1.1 & 0.7 & 1.0 \\
\hline Percent change & -23.0 & -3.0 & -22.3 & -32.4 & 38.6 \\
\hline Tea & 17.5 & 24.3 & 22.7 & 22.0 & 22.5 \\
\hline Percent change & -23.2 & 38.4 & -6.5 & -3.0 & 2.2 \\
\hline Volume ( 1,000 tons $)$ & 12.7 & 13.7 & 15.2 & 14.6 & 14.3 \\
\hline Percent change & -16.0 & 7.9 & 10.6 & -3.9 & -1.7 \\
\hline Unit value (f.o.b., U.S. dollars per kg.) & 1.4 & 1.8 & 1.5 & 1.5 & 1.6 \\
\hline Percent change & -8.6 & 28.3 & -15.4 & 0.9 & 3.9 \\
\hline Cassiterite and tin & 1.2 & 1.0 & 1.1 & 1.4 & 4.5 \\
\hline Percent change & 182.5 & -18.5 & 18.6 & 24.3 & 219.7 \\
\hline Volume (tons) & 529.0 & 365.0 & 555.0 & 672.0 & 1458.0 \\
\hline Percent change & 179.9 & -31.0 & 52.1 & 21.1 & 117.0 \\
\hline Unit value (U.S. dollars per kg.) & 2.2 & 2.6 & 2.0 & 2.1 & 3.1 \\
\hline Percent change & 0.9 & 18.1 & -22.0 & 2.7 & 47.4 \\
\hline Hides and skins & 0.5 & 0.4 & 0.8 & 2.6 & 3.8 \\
\hline Percent change & -73.6 & -20.6 & 83.0 & 238.3 & 43.7 \\
\hline Volume (tons) & 632.0 & 479.0 & 510.9 & 1983.8 & 2728.0 \\
\hline Percent change & -27.9 & -24.2 & 6.7 & 288.3 & 37.5 \\
\hline Unit value (U.S. dollars per kg.) & 0.9 & 0.9 & 1.5 & 1.3 & 1.4 \\
\hline Percent change & -63.4 & 4.7 & 71.9 & -13.1 & 4.5 \\
\hline Pyrethrum and chincona & 0.3 & 0.0 & 1.8 & 1.1 & 1.3 \\
\hline Percent change & -65.1 & -96.8 & 17612.0 & -40.2 & 20.9 \\
\hline Volume & 4.8 & 0.0 & 21.6 & 13.2 & 20.0 \\
\hline Percent change & -65.6 & -99.8 & 215900.0 & -38.9 & 51.5 \\
\hline Unit price (U.S. dollars per kg.) & 65.4 & 65.4 & 82.0 & 80.2 & 64.0 \\
\hline Percent change & 1.5 & 0.0 & 25.3 & -2.2 & -20.2 \\
\hline Other products & 15.9 & 41.6 & 47.8 & 25.6 & 16.0 \\
\hline Value index & 275.7 & 719.8 & 827.7 & 443.4 & 276.6 \\
\hline Percent change & 62.6 & 161.1 & 15.0 & -46.4 & -37.6 \\
\hline Volume index & 242.5 & 469.0 & 536.8 & 322.6 & 222.7 \\
\hline Percent change & 61.1 & 93.4 & 14.5 & -39.9 & -31.0 \\
\hline Price index $(1992=100)$ & 113.7 & 153.5 & 154.2 & 137.4 & 124.2 \\
\hline Percent change & 0.9 & 35.0 & 0.5 & -10.9 & -9.6 \\
\hline Other adjustments & 0.1 & 0.0 & 0.0 & 0.0 & 0.0 \\
\hline
\end{tabular}

Sources: National Bank of Rwanda (NBR); and Fund staff estimates.

CInternational Monetary Fund. Not for Redistribution 
Table 25. Rwanda: Imports, 1999-2003

(In millions of U.S. dollars, unless otherwise indicated)

\begin{tabular}{|c|c|c|c|c|c|}
\hline & 1999 & 2000 & 2001 & 2002 & 2003 \\
\hline Total c.i.f. & 316.7 & 327.7 & 312.6 & 320.2 & 325.2 \\
\hline Total, f.o.b. & 248.8 & 239.8 & 237.9 & 234.7 & 244.0 \\
\hline \multicolumn{6}{|l|}{ Moving indices $(1992=100)$} \\
\hline Price index & 95.2 & 107.3 & 104.1 & 109.6 & 113.5 \\
\hline Percent change & 2.9 & 12.7 & -3.0 & 5.4 & 3.5 \\
\hline Volume index & 108.4 & 92.7 & 94.8 & 88.8 & 89.2 \\
\hline Percent change & -5.5 & -14.5 & 2.3 & -6.4 & 0.4 \\
\hline \multicolumn{6}{|l|}{ Fixed indices $(1992=100)$} \\
\hline Price index & 96.5 & 106.8 & 103.2 & 110.5 & 114.0 \\
\hline Percent change & 4.8 & 10.6 & -3.3 & 7.1 & 3.1 \\
\hline Volume index & 106.9 & 93.2 & 95.6 & 88.1 & 88.8 \\
\hline Percent change & -7.2 & -12.8 & 2.6 & -7.9 & 0.8 \\
\hline Total, c.i.f. & 316.7 & 327.7 & 312.6 & 320.2 & 325.2 \\
\hline Capital goods & 55.4 & 53.0 & 50.6 & 55.5 & 61.2 \\
\hline Public & 49.8 & 47.7 & 45.5 & 49.9 & 55.4 \\
\hline Private & 5.5 & 5.3 & 5.1 & 5.5 & 5.8 \\
\hline Intermediate goods & 48.0 & 43.3 & 43.8 & 44.6 & 53.8 \\
\hline Energy products & 40.9 & 44.9 & 41.2 & 40.4 & 40.5 \\
\hline Other imports & 167.2 & 137.3 & 144.0 & 124.4 & 134.2 \\
\hline Food & 34.6 & 46.6 & 51.7 & 25.2 & 28.3 \\
\hline Other & 132.5 & 90.7 & 92.4 & 99.2 & 105.9 \\
\hline Other adjustments (elec. energy) & 5.3 & 49.1 & 33.0 & 55.3 & 35.5 \\
\hline \multicolumn{6}{|l|}{ By category } \\
\hline Capital goods & 55.4 & 53.0 & 50.6 & 55.5 & 61.2 \\
\hline Value index $(1992=100)$ & 80.2 & 76.8 & 73.3 & 80.4 & 88.7 \\
\hline Volume index $(1992=100)$ & 87.0 & 88.0 & 86.4 & 92.3 & 88.6 \\
\hline Percent change & -6.3 & 1.1 & -1.8 & 6.9 & -4.0 \\
\hline Price index $(1992=100)$ & 92.1 & 87.3 & 84.9 & 87.1 & 100.1 \\
\hline Percent change & -1.8 & -5.3 & -2.8 & 2.6 & 14.9 \\
\hline Intermediate goods & 48.0 & 43.3 & 43.8 & 44.6 & 53.8 \\
\hline Value index $(1992=100)$ & 51.9 & 46.9 & 47.3 & 48.3 & 58.2 \\
\hline Volume index $(1992=100)$ & 56.1 & 53.5 & 55.6 & 55.3 & 58.0 \\
\hline Percent change & -25.7 & -4.6 & 3.9 & -0.6 & 4.9 \\
\hline Price index $(1992=100)$ & 92.4 & 87.6 & 85.1 & 87.4 & 100.4 \\
\hline Percent change & -1.8 & -5.3 & -2.8 & 2.6 & 14.9 \\
\hline Energy products & 40.9 & 44.9 & 41.2 & 40.4 & 40.5 \\
\hline Value index $(1992=100)$ & 110.5 & 121.3 & 111.3 & 109.1 & 109.5 \\
\hline Volume index $(1992=100)$ & 112.7 & 78.8 & 83.9 & 80.2 & 69.5 \\
\hline Percent change & -14.5 & -30.1 & 6.5 & -4.4 & -13.4 \\
\hline Price index $(1992=100)$ & 98.1 & 154.0 & 132.7 & 136.1 & 157.6 \\
\hline Percent change & 37.5 & 57.0 & -13.8 & 2.5 & 15.8 \\
\hline Food & 34.6 & 46.6 & 51.7 & 25.2 & 28.3 \\
\hline Value index $(1992=100)$ & 119.4 & 160.8 & 178.3 & 87.0 & 97.8 \\
\hline Volume index $(1992=100)$ & 134.3 & 177.7 & 192.6 & 93.3 & 99.1 \\
\hline Percent change & -31.8 & 32.3 & 8.4 & -51.6 & 6.2 \\
\hline Price index $(1992=100)$ & 89.0 & 90.5 & 92.6 & 93.2 & 98.7 \\
\hline Percent change & -11.6 & 1.7 & 2.3 & 0.7 & 5.9 \\
\hline Other & 132.5 & 90.7 & 92.4 & 99.2 & 105.9 \\
\hline Value index $(1992=100)$ & 215.6 & 147.5 & 150.3 & 161.4 & 172.2 \\
\hline Volume index $(1992=100)$ & 189.0 & 127.5 & 127.6 & 134.9 & 142.1 \\
\hline Percent change & 25.1 & -32.5 & -- & 5.8 & 5.3 \\
\hline Price index $(1992=100)$ & 114.1 & 115.7 & 117.8 & 119.6 & 121.2 \\
\hline Percent change & 0.9 & 1.4 & 1.8 & 1.6 & 1.3 \\
\hline
\end{tabular}

Sources: National Bank of Rwanda (NBR); and Fund staff estimates.

CInternational Monetary Fund. Not for Redistribution 
Table 26. Rwanda: Services and Transfers, 1999-2003

(In millions of U.S. dollars)

\begin{tabular}{|c|c|c|c|c|c|}
\hline & 1999 & 2000 & 2001 & 2002 & 2003 \\
\hline Services (net) & -143.0 & -141.4 & -125.3 & -125.1 & -143.4 \\
\hline Credit & 51.1 & 59.9 & 63.6 & 65.4 & 76.5 \\
\hline Nonfactor services (net) & -143.0 & -141.4 & -125.3 & -125.1 & -143.4 \\
\hline Credit & 51.1 & 59.9 & 63.6 & 65.4 & 76.5 \\
\hline Freight & 5.8 & 5.6 & 5.4 & 2.2 & 4.5 \\
\hline Other transportation & 9.3 & 8.6 & 8.6 & 10.0 & 13.9 \\
\hline Travel & 17.0 & 23.5 & 24.7 & 31.1 & 30.1 \\
\hline Foreign governments & 14.7 & 18.7 & 20.4 & 17.7 & 22.7 \\
\hline Other & 4.3 & 3.4 & 4.4 & 4.3 & 5.3 \\
\hline Debit & 194.1 & 201.3 & 188.9 & 190.4 & 219.9 \\
\hline Freight & 48.2 & 58.6 & 53.1 & 60.7 & 55.2 \\
\hline Other transportation & 25.0 & 24.9 & 25.3 & 28.9 & 39.2 \\
\hline Travel (excluding bourses) & 18.3 & 21.9 & 23.2 & 23.9 & 26.1 \\
\hline Government of Rwanda (net) & 12.2 & 19.2 & 12.2 & 13.6 & 20.0 \\
\hline Private services & 14.2 & 8.2 & 11.6 & 10.8 & 16.1 \\
\hline Technical assistance & 76.3 & 68.5 & 63.6 & 52.5 & 63.4 \\
\hline Other (adjustment) & 12.8 & 17.2 & 17.7 & 20.9 & 19.9 \\
\hline Factor services (net) & -11.4 & -15.4 & -22.5 & -19.1 & -30.5 \\
\hline Credit & 7.8 & 13.9 & 13.8 & 8.5 & 6.2 \\
\hline Investment income & 7.8 & 10.8 & 11.7 & 8.5 & 6.0 \\
\hline Other & -- & 3.0 & 2.1 & 0.0 & 0.2 \\
\hline Debit & 19.2 & 29.2 & 36.3 & 27.5 & 36.7 \\
\hline Dividends and private investment income & 1.2 & 3.3 & 4.4 & 0.5 & 6.6 \\
\hline Investment income & 13.3 & 13.2 & 14.0 & 13.2 & 15.4 \\
\hline Labor income & 4.1 & 12.2 & 17.5 & 13.6 & 14.5 \\
\hline Property income & 0.6 & 0.6 & 0.4 & 0.2 & 0.3 \\
\hline Transfers (net) & 263.7 & 288.5 & 255.3 & 236.4 & 264.9 \\
\hline Credit & 276.5 & 305.6 & 273.1 & 257.3 & 284.9 \\
\hline Debit & 12.8 & 17.2 & 17.7 & 20.9 & 19.9 \\
\hline Private (net) & 18.2 & 11.0 & 21.7 & 24.5 & 31.3 \\
\hline Credit & 29.7 & 27.3 & 38.1 & 43.6 & 49.4 \\
\hline Debit & 11.6 & 16.3 & 16.4 & 19.0 & 18.1 \\
\hline Public (net) & 245.6 & 277.4 & 233.6 & 211.9 & 233.6 \\
\hline Credit & 246.8 & 278.3 & 234.9 & 213.8 & 235.5 \\
\hline Current grants for budgetary support & 39.7 & 101.5 & 77.5 & 82.9 & 95.8 \\
\hline Support for public investment projects & 70.1 & 71.8 & 63.4 & 41.6 & 41.1 \\
\hline Other current grants & 137.1 & 105.0 & 94.0 & 89.3 & 98.6 \\
\hline Debit & 1.3 & 0.9 & 1.3 & 1.9 & 1.9 \\
\hline
\end{tabular}

Sources: National Bank of Rwanda (NBR); and Fund staff estimates. 
Table 27. Rwanda: Scheduled Principal and Interest, 1999-2003 1/2 (In millions of U.S. dollars)

\begin{tabular}{|c|c|c|c|c|c|c|c|c|c|c|}
\hline & \multicolumn{2}{|c|}{1999} & \multicolumn{2}{|c|}{2000} & \multicolumn{2}{|c|}{2001} & \multicolumn{2}{|c|}{2002} & \multicolumn{2}{|c|}{2003} \\
\hline & Principal & Interest & Principal & Interest & Principal & Interest & Principal & Interest & Principal & 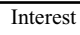 \\
\hline Total & 41.6 & 10.2 & 30.7 & 11.8 & 36.6 & 11.5 & 33.3 & 12.3 & 28.8 & 14.2 \\
\hline IBRD-IDA & 5.3 & 4.6 & 6.4 & 5.2 & 8.7 & 5.1 & 10.6 & 5.2 & 12.2 & 6.9 \\
\hline African Development Fund & 2.6 & 1.6 & 3.1 & 1.6 & 3.3 & 1.6 & 4.5 & 2.0 & 3.6 & 1.9 \\
\hline African Development Bank & 0.5 & 0.3 & 0.6 & 0.3 & 0.6 & 0.2 & 0.5 & 0.4 & 0.4 & 0.2 \\
\hline International Fund for Agricultural Development & 0.2 & 0.3 & 0.2 & 0.3 & 0.3 & 0.3 & 0.8 & 0.4 & 1.1 & 0.4 \\
\hline Arab Bank for Economic Development in Africa (BADEA) & 2.6 & 0.0 & 2.0 & 0.9 & 3.8 & 0.8 & 3.4 & 0.2 & 3.4 & 0.8 \\
\hline Arab League & 0.0 & 0.0 & 0.0 & 0.0 & 0.0 & 0.0 & - & - & - & - \\
\hline European Union/European Investment Bank & 1.5 & 0.3 & 1.3 & 0.3 & 1.3 & 0.3 & 1.2 & 0.3 & 1.4 & 0.3 \\
\hline OPEC Fund & 0.4 & 0.0 & 0.4 & 0.0 & 0.4 & 0.0 & 0.1 & 0.1 & 0.1 & 0.3 \\
\hline IMF & 8.5 & 1.4 & 11.1 & 1.4 & 10.6 & 1.0 & 6.7 & 0.6 & 1.7 & 0.4 \\
\hline Bilateral & 20.0 & 1.8 & 5.4 & 1.5 & 7.7 & 1.9 & 5.5 & 3.0 & 4.8 & 2.9 \\
\hline Paris Club & 4.9 & 1.3 & 0.0 & 1.3 & 2.3 & 1.7 & 3.4 & 1.7 & 3.5 & 1.7 \\
\hline Official development assistance (ODA) & 3.7 & 1.0 & 0.0 & 0.6 & 2.1 & 1.0 & 3.2 & 1.1 & 3.5 & 1.2 \\
\hline Austria & 0.2 & 0.2 & 0.0 & 0.0 & 0.4 & 0.1 & 0.4 & 0.1 & 0.4 & 0.1 \\
\hline France & 2.8 & 0.7 & 0.0 & 0.5 & 1.3 & 0.7 & 2.2 & 0.8 & 2.5 & 0.9 \\
\hline Japan & 0.7 & 0.2 & 0.0 & 0.1 & 0.4 & 0.2 & 0.6 & 0.2 & 0.7 & 0.2 \\
\hline Non-ODA & 1.2 & 0.2 & 0.0 & 0.7 & 0.2 & 0.7 & 0.2 & 0.6 & 0.0 & 0.5 \\
\hline Canada & 0.3 & 0.1 & 0.0 & 0.2 & 0.2 & 0.2 & 0.2 & 0.2 & 0.0 & 0.1 \\
\hline France & 0.9 & 0.2 & 0.0 & 0.4 & 0.0 & 0.4 & 0.0 & 0.4 & 0.0 & 0.4 \\
\hline United States & 0.0 & 0.0 & 0.0 & 0.0 & 0.0 & 0.0 & 0.0 & 0.0 & 0.0 & 0.0 \\
\hline Non-Paris Club & 15.1 & 0.5 & 5.4 & 0.3 & 5.4 & 0.2 & 2.2 & 1.3 & 1.3 & 1.2 \\
\hline ODA & 15.1 & 0.5 & 5.4 & 0.3 & 5.4 & 0.2 & 2.2 & 1.3 & 1.3 & 1.2 \\
\hline China & 2.2 & 0.0 & 2.2 & 0.0 & 2.2 & 0.0 & 0.0 & 0.0 & 0.7 & 0.0 \\
\hline Abu Dhabi Fund for Development & 0.1 & 0.0 & 0.0 & 0.0 & 0.0 & 0.0 & 0.4 & 0.1 & 0.3 & 0.1 \\
\hline Kuwaiti Fund for Arab Economic Development & 1.8 & 0.3 & 1.6 & 0.1 & 1.6 & 0.1 & 1.7 & 0.5 & 0.0 & 0.5 \\
\hline Libya & 0.1 & 0.0 & 0.0 & 0.0 & 0.0 & 0.0 & 0.0 & 0.0 & 0.0 & 0.0 \\
\hline Saudi Fund for Development & 2.1 & 0.2 & 1.6 & 0.1 & 1.6 & 0.1 & 0.1 & 0.6 & 0.3 & 0.5 \\
\hline Unallocated amounts & 8.8 & 0.0 & 0.0 & 0.0 & 0.0 & 0.0 & 0.0 & 0.0 & 0.0 & 0.0 \\
\hline Non-ODA & 0.0 & 0.0 & 0.0 & 0.0 & 0.0 & 0.0 & 0.0 & 0.0 & 0.0 & 0.0 \\
\hline Commercial & 0.0 & 0.0 & 0.0 & 0.0 & 0.0 & 0.0 & 0.0 & 0.1 & 0.0 & 0.1 \\
\hline Banque Nationale de Paris (BNP)/Amsterdam & 0.0 & 0.0 & 0.0 & 0.0 & 0.0 & 0.0 & 0.0 & 0.1 & 0.0 & 0.1 \\
\hline $\mathrm{BNP} /$ Paris & 0.0 & 0.0 & 0.0 & 0.0 & 0.0 & 0.0 & 0.0 & 0.0 & 0.0 & 0.0 \\
\hline
\end{tabular}

Source: National Bank of Rwanda.

1/ Excluding rescheduling and new drawings.

2/ The stock of debt in 1999 has been adjusted to include amounts previously rescheduled. 
Table 28. Rwanda: External Public Debt, Stock Outstanding, 1999-2003 1/ (In millions of U.S. dollars)

\begin{tabular}{|c|c|c|c|c|c|}
\hline & 1999 & 2000 & 2001 & 2002 & 2003 \\
\hline Total external debt & 1256.5 & 1300.5 & 1336.1 & 1401.0 & 1432.8 \\
\hline IBRD-IDA & 691.1 & 722.4 & 767.4 & 833.9 & 847.3 \\
\hline African Development Fund & 218.3 & 219.3 & 228.0 & 226.7 & 222.4 \\
\hline African Development Bank & 7.3 & 5.8 & 5.2 & 4.6 & 4.0 \\
\hline International Fund for Agricultural Development & 32.9 & 36.7 & 42.1 & 40.6 & 40.1 \\
\hline Arab Bank for Economic Development in Africa (BADEA) & 28.3 & 27.5 & 25.0 & 23.0 & 19.6 \\
\hline Arab League & 0.0 & 0.0 & 0.0 & 0.0 & 0.0 \\
\hline European Union/European Investment Bank & 29.4 & 28.2 & 26.8 & 25.5 & 32.8 \\
\hline European Union & 29.4 & 28.1 & 26.8 & 25.5 & 24.1 \\
\hline European Investment Bank & 0.0 & 0.1 & 0.0 & 0.0 & 8.6 \\
\hline OPEC Fund & 6.7 & 6.8 & 6.4 & 9.8 & 15.5 \\
\hline IMF & 75.9 & 85.8 & 84.3 & 84.9 & 91.9 \\
\hline Bilateral & 166.1 & 167.4 & 150.4 & 151.5 & 158.6 \\
\hline Paris Club & 73.0 & 73.0 & 74.1 & 75.5 & 76.7 \\
\hline Official development assistance (ODA) & 62.6 & 62.6 & 63.6 & 64.9 & 66.1 \\
\hline Austria & 9.3 & 9.3 & 9.4 & 9.5 & 9.7 \\
\hline France & 38.1 & 38.1 & 38.9 & 39.8 & 40.7 \\
\hline Japan & 15.2 & 15.2 & 15.4 & 15.6 & 15.8 \\
\hline Non-ODA & 10.4 & 10.4 & 10.5 & 10.6 & 10.7 \\
\hline Canada & 3.0 & 3.0 & 2.9 & 2.8 & 2.8 \\
\hline France & 6.9 & 6.9 & 7.1 & 7.2 & 7.3 \\
\hline United States & 0.6 & 0.6 & 0.6 & 0.6 & 0.6 \\
\hline Non-Paris Club & 93.1 & 94.3 & 76.3 & 76.0 & 81.8 \\
\hline ODA & 93.1 & 94.3 & 76.3 & 76.0 & 81.8 \\
\hline China & 32.0 & 32.1 & 14.3 & 14.2 & 15.9 \\
\hline Abu Dhabi Fund for Development & 2.5 & 2.5 & 2.5 & 2.5 & 5.0 \\
\hline Kuwaiti Fund for Arab Economic Development & 27.6 & 27.7 & 27.8 & 27.8 & 27.9 \\
\hline Libya & 1.1 & 1.1 & 1.1 & 1.1 & 2.2 \\
\hline Saudi Fund for Development & 30.0 & 30.9 & 30.7 & 30.4 & 30.9 \\
\hline Unallocated amounts & 0.0 & 0.0 & 0.0 & 0.0 & 0.0 \\
\hline Non-ODA & 0.0 & 0.0 & 0.0 & 0.0 & 0.0 \\
\hline Commercial & 0.5 & 0.6 & 0.5 & 0.6 & 0.6 \\
\hline Banque Nationale de Paris (BNP)/ Amsterdam & 0.5 & 0.6 & 0.5 & 0.6 & 0.6 \\
\hline $\mathrm{BNP} /$ Paris & 0.0 & 0.0 & 0.0 & 0.0 & 0.0 \\
\hline
\end{tabular}

Sources: Rwandese authorities; and Fund staff estimates.

1/ After rescheduling, including arrears. 
Table 29. Rwanda: External Debt, Outstanding Arrears, 1999-2003

(In millions of U.S. dollars; end of period)

\begin{tabular}{|c|c|c|c|c|c|}
\hline & 1999 & 2000 & 2001 & 2002 & 2003 \\
\hline Total & 54.1 & 61.2 & 23.2 & 31.8 & 14.7 \\
\hline IBRD-IDA & 0.0 & 0.0 & 0.0 & 0.0 & 0.0 \\
\hline African Development Fund & 0.0 & 0.0 & 0.0 & 0.0 & 0.0 \\
\hline African Development Bank & 0.0 & 0.0 & 0.0 & 0.0 & 0.0 \\
\hline International Fund for Agricultural Development & 1.0 & 1.0 & 1.0 & 0.0 & 0.0 \\
\hline Arab Bank for Economic Development in Africa (BADEA) & 0.0 & 0.0 & 0.0 & 0.1 & 0.0 \\
\hline Arab League & 0.0 & 0.0 & 0.0 & 0.0 & 0.0 \\
\hline European Union/European Investment Bank & 0.0 & 0.1 & 0.0 & 0.0 & 0.0 \\
\hline OPEC Fund & 5.5 & 6.0 & 0.0 & 2.9 & 0.0 \\
\hline IMF & 0.0 & 0.0 & 0.0 & 0.0 & 0.0 \\
\hline Bilateral & 47.6 & 54.1 & 22.2 & 28.8 & 14.7 \\
\hline Paris Club & 0.0 & 0.0 & 0.0 & 5.8 & 11.4 \\
\hline Official development assistance (ODA) & 0.0 & 0.0 & 0.0 & 5.8 & 10.9 \\
\hline Austria & 0.0 & 0.0 & 0.0 & 0.0 & 0.0 \\
\hline France & 0.0 & 0.0 & 0.0 & 4.6 & 8.8 \\
\hline Overseas Economic Cooperation Fund (Japan) & 0.0 & 0.0 & 0.0 & 1.2 & 2.1 \\
\hline Non-ODA & 0.0 & 0.0 & 0.0 & 0.0 & 0.5 \\
\hline Canada & 0.0 & 0.0 & 0.0 & 0.0 & 0.2 \\
\hline France & 0.0 & 0.0 & 0.0 & 0.0 & 0.3 \\
\hline United States & 0.0 & 0.0 & 0.0 & 0.0 & 0.0 \\
\hline Non-Paris Club & 47.6 & 54.1 & 22.2 & 23.0 & 3.3 \\
\hline ODA & 47.6 & 54.1 & 22.2 & 23.0 & 3.3 \\
\hline China & 10.6 & 12.8 & 0.0 & 0.0 & 0.2 \\
\hline Abu Dhabi Fund for Development & 2.5 & 2.5 & 2.5 & 2.7 & 2.7 \\
\hline Kuwaiti Fund for Arab Economic Development & 15.3 & 17.0 & 18.6 & 19.9 & 0.0 \\
\hline Libya & 1.1 & 1.1 & 1.1 & 0.4 & 0.4 \\
\hline Saudi Fund for Development & 18.1 & 20.7 & 0.0 & 0.0 & 0.0 \\
\hline Unallocated amounts & 0.0 & 0.0 & 0.0 & 0.0 & 0.0 \\
\hline Non-ODA & 0.0 & 0.0 & 0.0 & 0.0 & 0.0 \\
\hline Commercial & 0.0 & 0.0 & 0.0 & 0.0 & 0.0 \\
\hline Banque Nationale de Paris (BNP)/Amsterdam & 0.0 & 0.0 & 0.0 & 0.0 & 0.0 \\
\hline $\mathrm{BNP} /$ Paris & 0.0 & 0.0 & 0.0 & 0.0 & 0.0 \\
\hline
\end{tabular}

Sources: National Bank of Rwanda; and Ministry of Finance and Economic Planning. 